*ak FMIS View/Frint Document Cover Sheet tow

This document was retrieved from the Documentation and Records Manaqement (DRM) ISEARCH System. It is intended for Information only and may not be the most recent or updated version. Contact a Document Service Center (see Hanford Info for locations) if you need additional retrieval information.

Accession \#: D196003124

Document \#: SD-WM-ER-515

Title/Desc:

WASTE TANK 241SY101 DOME AIRSPACE \& VENTILATION SYSTEM RESPONSE TO A FLAMMABLE GAS PLUME BURN

Pages: 84 


\begin{tabular}{|c|c|c|}
\hline $\begin{array}{l}\text { 2. To: (Receiving Organization) } \\
\text { Distribution }\end{array}$ & $\begin{array}{l}\text { 3. Fron: (originating Organization) } \\
\text { Plant Systems Safety Basis }\end{array}$ & $\begin{array}{r}\text { 4. Related EDT No.: } \\
\text { NA }\end{array}$ \\
\hline 5. Proj./Prog./Dept./Div.: & $\begin{array}{l}\text { 6. Cos. Engr.: } \\
\text { F. J. Heard }\end{array}$ & $\begin{array}{l}\text { 7. Purchase Ordar No.: } \\
\text { NA }\end{array}$ \\
\hline \multirow{2}{*}{\multicolumn{2}{|c|}{$\begin{array}{l}\text { 8. Originator Remarks: } \\
\text { Approva } 1 / \text { Rel ease }\end{array}$}} & $\begin{array}{l}\text { 9. Equip./Component No.: } \\
\text { NA }\end{array}$ \\
\hline & & $\begin{array}{l}\text { 10. System/Bldg./Facility: } \\
\text { NA }\end{array}$ \\
\hline \multirow[t]{3}{*}{ 11. Receiver Remarks: } & & $\begin{array}{l}\text { 12. Major Assm. Dwg. No.: } \\
\text { NA }\end{array}$ \\
\hline & & $\begin{array}{l}\text { 13. Permit/Permit Application No.: } \\
\text { NA }\end{array}$ \\
\hline & & $\begin{array}{l}\text { 14. Required Response Date: } \\
12-22-95\end{array}$ \\
\hline
\end{tabular}

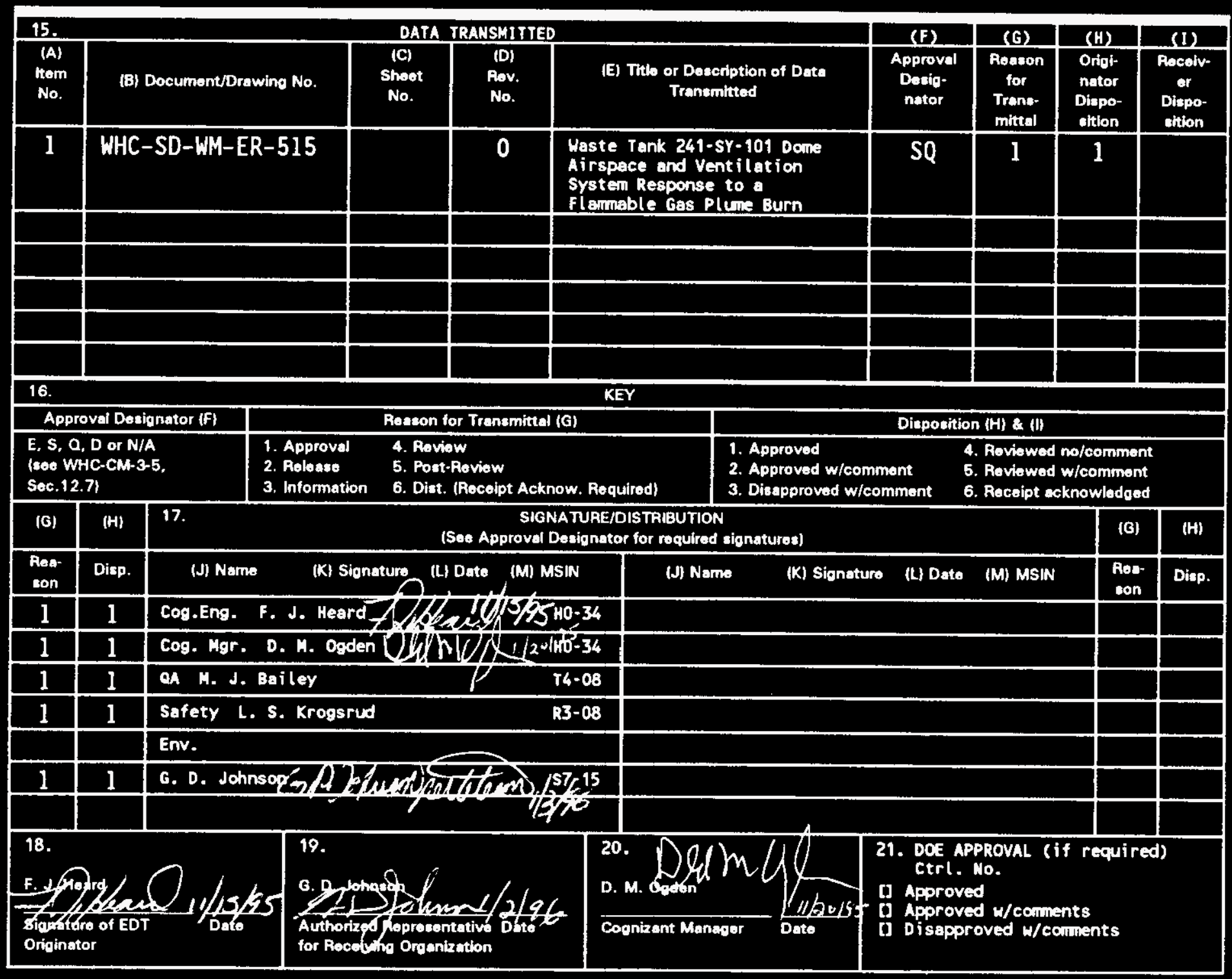

BD-7400-172-2(04/94) GEF097 


\section{\begin{tabular}{l|l} 
1. EDT 603225 \\
\hline
\end{tabular}}

\begin{tabular}{|l|l|}
\hline $\begin{array}{l}\text { 2. To: (Receiving organization) } \\
\text { Distribution }\end{array}$ & $\begin{array}{l}\text { 3. From: (Originating Organization) } \\
\text { Plant Systems Safety Basis }\end{array}$ \\
\hline 5. Proj./Prog./Dept./Div.: & 6. Cog. Engr.: \\
& F. J. Heard \\
\hline
\end{tabular}

8. Originator Remarks:

4. Related EDT NO.:

7. Purchase Order No.:

NA

9. Equip./Component No.:

NA

10. System/Bldg./Facility:

NA

11. Receiver Remarks:

12. Major Assm. Dwg. No.: NA

13. Permit/Permit Application No.: NA

14. Required Respanse Date: $-11-27-95-2$

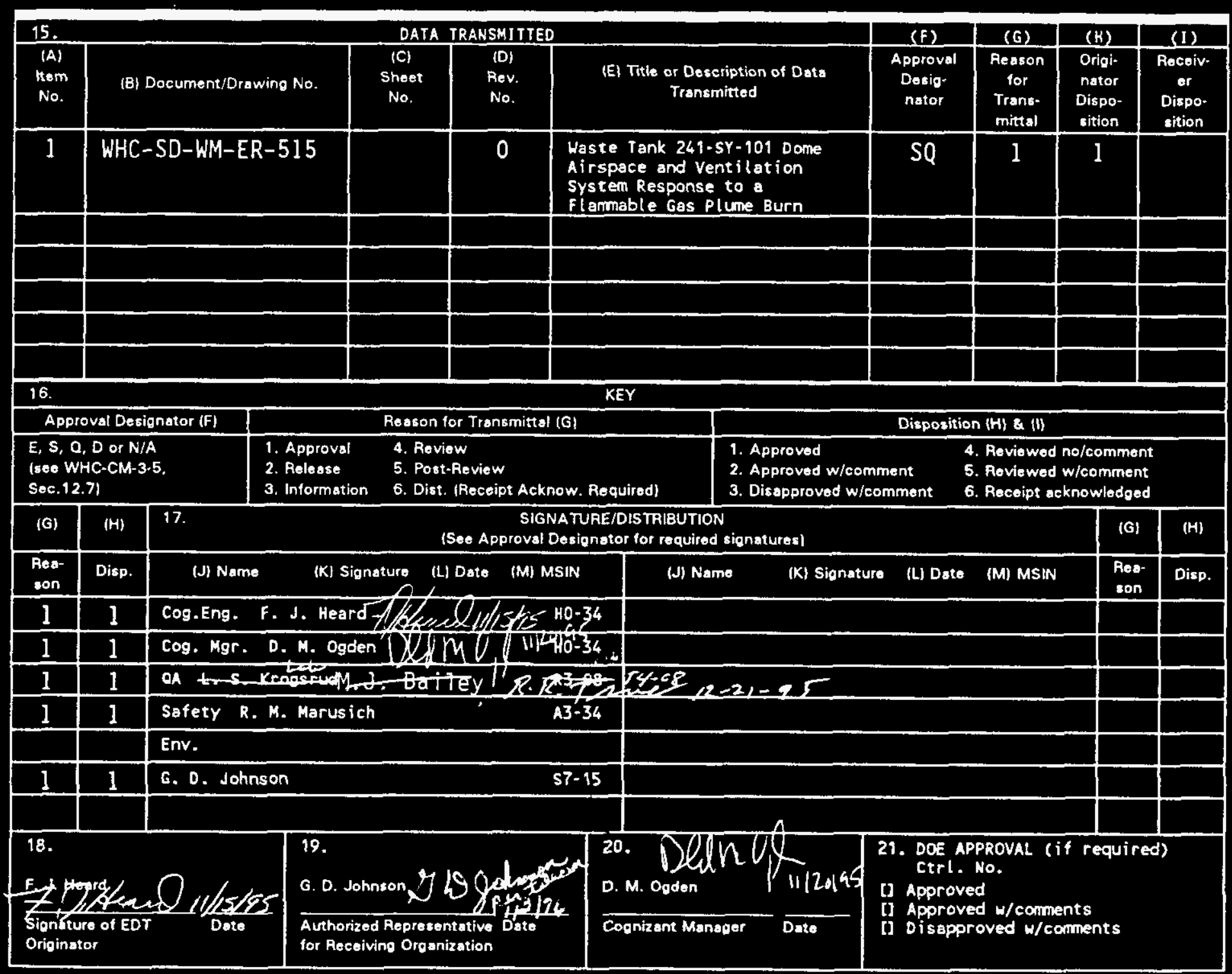

8D-7400-172-2(04/94) GEF097 


\section{ENGINEERING DATA TRANSMITTAL}

1. EOT 603225

\begin{tabular}{|c|c|c|}
\hline $\begin{array}{l}\text { 2. To: (Receiving Organization) } \\
\text { Distribution }\end{array}$ & $\begin{array}{l}\text { 3. From: (originasing organization) } \\
\text { Plant Systems Safety Basis }\end{array}$ & $\begin{array}{r}\text { 4. Related EDT No.: } \\
\text { NA }\end{array}$ \\
\hline 5. Proj./Prog./Dept./Div.: & $\begin{array}{l}\text { 6. Cog. Engr.: } \\
\text { F. J. Heard }\end{array}$ & $\begin{array}{l}\text { 7. Purchase Order No.: } \\
\text { NA }\end{array}$ \\
\hline \multirow{2}{*}{\multicolumn{2}{|c|}{ 8. Originator Renarks: }} & $\begin{array}{l}\text { 9. Equip./Component No.: } \\
\text { NA }\end{array}$ \\
\hline & & $\begin{array}{l}\text { 10. System/sidg./Facility: } \\
\text { NA }\end{array}$ \\
\hline \multirow[t]{3}{*}{ 11. Receiver Renarks: } & & $\begin{array}{l}\text { 12. Hajor Assm. Dwg. Mo.: } \\
\text { NA }\end{array}$ \\
\hline & & $\begin{array}{l}\text { 13. Permit/Permit Application Ho.: } \\
\text { NA }\end{array}$ \\
\hline & & $\begin{array}{l}\text { 14. Required Response Date: } \\
. .+11-27095-i=5\end{array}$ \\
\hline
\end{tabular}

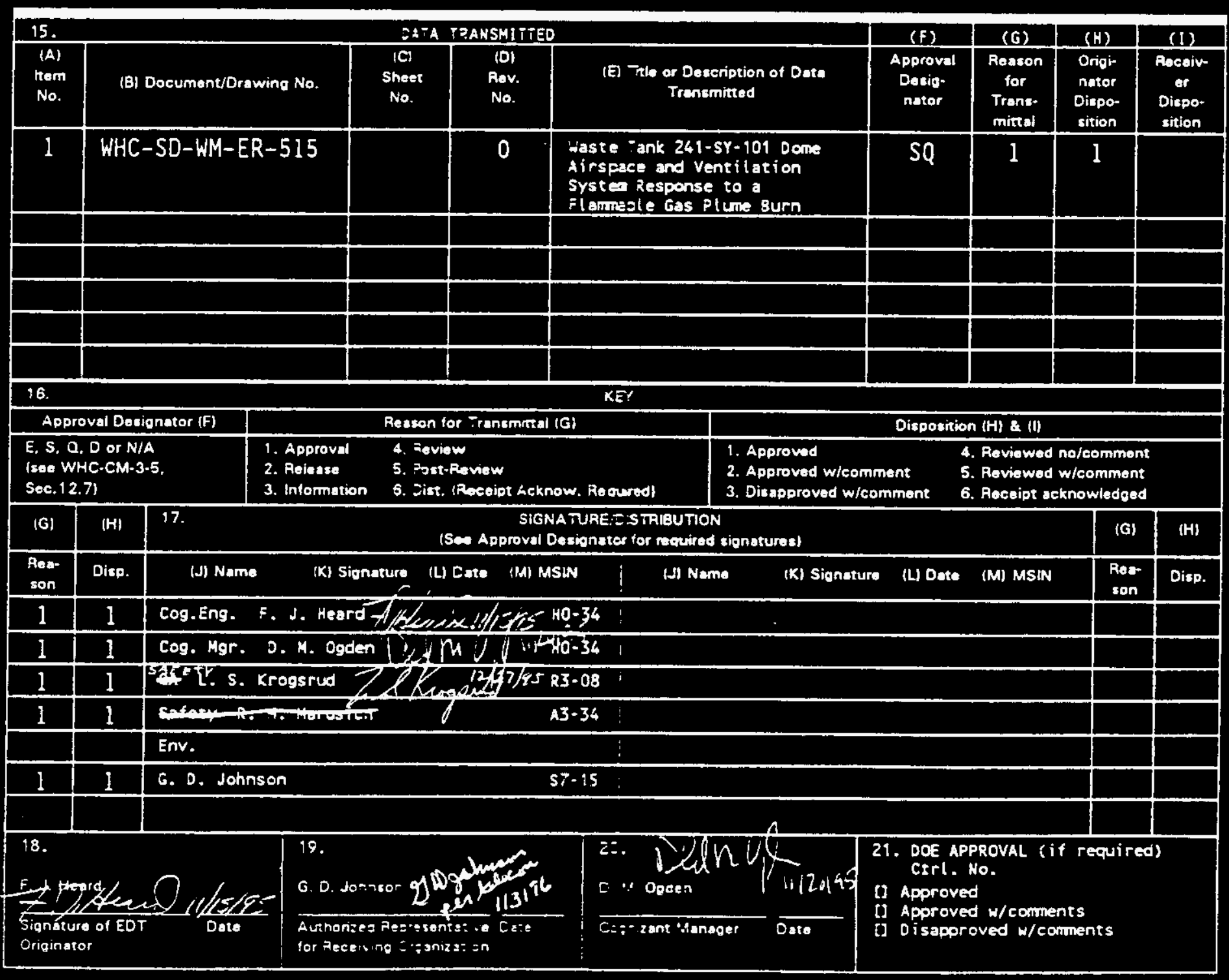

$30-7400-172 \cdot 2(04 / 94)$ GE: :=- 


\title{
Waste Tank 241-SY-101 Dome Airspace and Ventilation System Response to a Flammable Gas Plume Burn
}

\author{
F. J. Heard
}

Westinghouse Hanford Company, Richland, WA 99352

U.S. Department of Energy Contract DE-AC06-87RL10930

\author{
EDT/ECN: 613538 \\ Org Code: W74010 \\ B\&R Code: EW3135040
UC: 2020
Charge Code: N2150 \\ Total Pages: 79
}

Key Words: Flammable, Gas, Plume, Burn, Chemical Reactions, Waste Tank, Dome. Airspace, Ventilation System, HEPA. Pressure, Compressible,

Hydrogen, Nitrous Oxide, Ammonia

\section{Abstract:}

A series of flammable gas plume burn and transient pressure analyses have been completed for a nuclear waste tank (241-SY-101) and associated tank farm ventilation system at the U.S. Department of Energy's Hanford facility. The subject analyses were performed to address issues concerning the effects of transient pressures resulting from igniting a small volume of concentrated flammable gas just released from the surface of the waste as a plume and before the flammable gas concentration could be reduced by mixing with the dome airspace by local convection and turbulent diffusion. Such a condition may exist as part of an inprogress episode gas release (EGR) or gas plume event. The analysis goal was to determine the volume of flammable gas that if burned within the dome airspace would result in a differential pressure, after propagating through the ventilation system, greater than the current High Efficiency Particulate Filter (HEPA) limit of $2.49 \mathrm{KPa}$ (10 inches of water or 0.36 psi). Such a pressure wave could rupture the tank ventilation system iniet and outlet HEPA filters leading to a potential relase of contaminants to the environment.

TRADEMARK DISCLAIMER. Reference herein to any specific commercial product, process, or service by trade name, trademark, manufacturer, or otherwise, does not necessarily constitute or imply its endorsenent, recommendation, or favoring by the United States Government or any agency thereof or its contractors or subcontractors.

Printed in the United States of America. To obtain copies of this document, contact: HHC/BCS Document Control Services, P.0. Box 1970, Mailstop H6-08, Richland WA 99352, Phone (509) 372-2420; Fax (509) 376-4989.
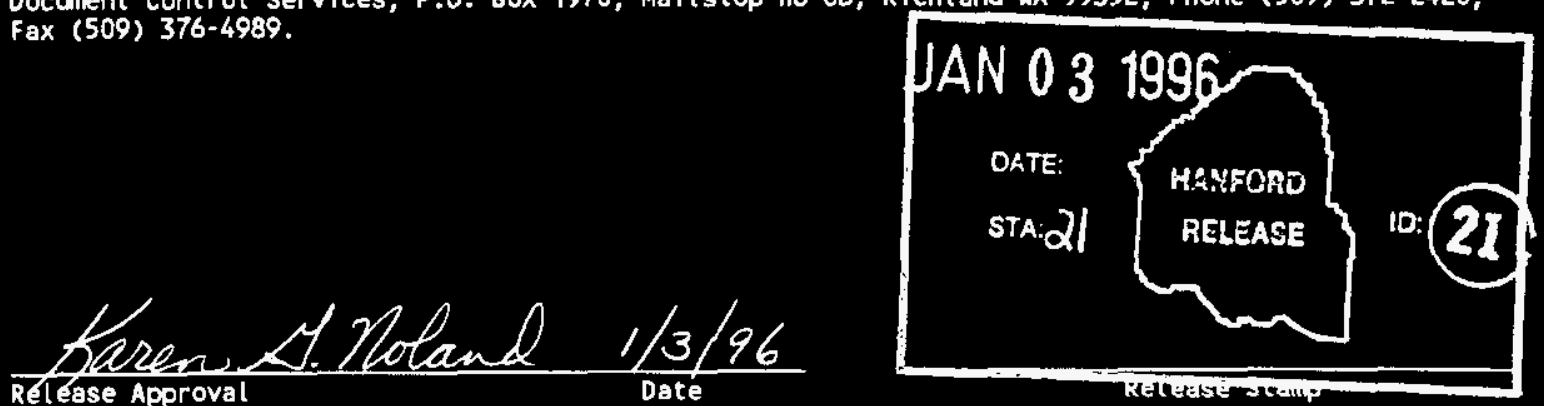

\section{Approved for Public Release}




\title{
Waste Tank 241-SY-101 Dome Airspace and Ventilation System Response to a Flammable Gas Plume Burn
}

\author{
F. J. Heard
}

November 1995

\author{
Issued by \\ WESTINGHOUSE HANFORD COMPANY \\ for the
}

U.S. DEPARTMENT OF ENERGY RICHLAND OPERATIONS OFFICE

RICHLAND, WASHINGTON 
WHC-SD-WM-ER-515, Rev. 0

241-SY-101 WASTE TANK AIRSPACE AND VENTILATION SYSTEM RESPONSE TO FLANMABLE gAS PLUNE BURUS

\author{
F. J. Heard
}

\title{
ABSTRACT
}

A series of flammable gas plume burn and transient pressure analyses have been completed for Waste Tank 241-SY-101 and associated tank farm ventilation system at the U.S. Department of Energy's Hanford Site. These analyses were performed to address issues concerning the effects of transient pressures resulting from igniting a small volume of concentrated flammable gas just released from the surface of the waste as a plume before mixing with the dome airspace by local convection and turbulent diffusion could reduce the flammable gas concentration. Such a condition may exist as part of an inprogress episodic gas release or gas plume event. The analysis goal was to determine the volume of flammable gas that, if burned within the dome airspace, would result in a differential pressure, after propagating through the ventilation system, greater than the current high-efficiency-particulateair-filter limit of $2.49 \mathrm{KPa}$ (10 inches of water or $0.36 \mathrm{psi}$ ). Such a pressure wave could rupture the tank ventilation system inlet and outlet highefficiency-particulate-air-filters leading to a potential release of contaminants to the environment. 


\section{EXECUTIVE SUNMARY}

A series of flammable gas combustion and transient-compressible pressure analyses were completed for Waste Tank 241-SY-101 and the associated SY tank farm ventilation system. The analyses were performed using a computer model that was benchmarked against U.S. Bureau of Mines (BOM) data.

The subject analyses were performed to address issues concerning the effects of igniting a small volume of concentrated flammable gas just released from the waste as a plume before mixing with the dome airspace by local convection and turbulent diffusion could reduce the flammable gas concentration. Such a condition may exist as part of an in-progress episodic gas release (EGR) or gas plume event. The analysis goal was to determine the volume of flammable gas that, if burned within the dome airspace, would result in a differential pressure, after propagating through the ventilation system, greater than the current high-efficiency-particulate-air-filter (HEPA) 1 imit of $2.49 \mathrm{KPa}(10$ inches of water or $0.36 \mathrm{psi})$. Such a pressure wave could rupture the tank ventilation system inlet and outlet HEPA filters leading to a potential release of contaminants to the environment.

The results indicate that the differential pressure limit for the SY-101 tank inlet HEPA filter will be exceeded for flammable gas plume burns of greater than $75 \mathrm{ft}^{3}$. A flammable gas release of less than $75 \mathrm{ft}^{3}$ would be required for the differential pressure limit to not be exceeded during a plume burn. Flammable gas plume burns of less than $75 \mathrm{ft}^{3}$ were not investigated.

The differential pressure limit for the SY tank farm outlet HEPA filter is not exceeded for flammable gas plume burns of 75 and $150 \mathrm{ft}^{3}$. However, a flammable gas plume burn of $300 \mathrm{ft}^{3}$ will exceed the differential pressure 
WHC-SD-WM-ER-515, Rev. 0

limit of the outlet HEPA filter. A simple first order estimate using linear interpolation indicated that the differential pressure 1 imit of $0.36 \mathrm{psi}$ is reached for a $\mathrm{flammable} \mathrm{gas} \mathrm{plume} \mathrm{burn} \mathrm{of} 190 \mathrm{ft}^{3}$. This remains to be confirmed.

The number of simulated potential chemical reactions appears to have a minor effect on the results. The volume of flammable gas has a much greater effect.

It must be emphasized that the results presented in this report reflect only the tank SY-101 and SY tank farm ventilation system. Other tanks with different dome airspace volumes, gas composition, ventilation system configuration, etc., will respond differently to a flammable gas plume burn. It is expected that a small flammable gas plume burn within tanks without an active ventilation system will exceed the pressure limit for both the inlet and outlet HEPA filters. This is especially true for most single-she1l tanks where the ventilation system usually consists of one or two HEPA filters on small-diameter ( 4 in.) risers and relies on natural breathing due to barometric pressure changes. (The notable exception to this is the singleshell SX tank farm, which has an active ventilation system.) 
1.0 IKTRODUCTION ....................... 1-1

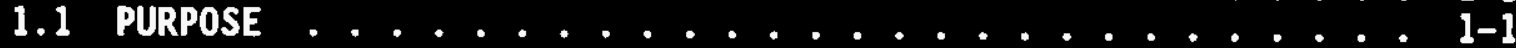

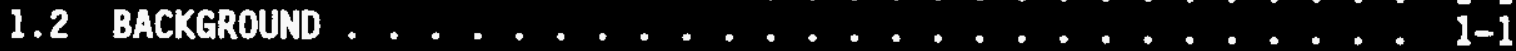

2.0 TECHNICAL BASES .................. 2-1

2.1 CODE DESCRIPTION ..........................

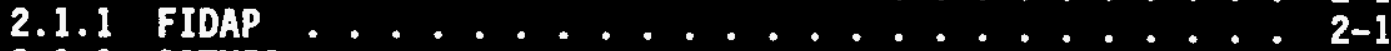

2.1 .2 GOTHIC . . . . . . . . . 2-1

2.2 CHEMICAL REACTION CAPABILITY $\therefore \ldots$

2.3 THERMOPHYSICAL PROPERTIES ..................... 2-3

2.3.1 Density Formulation for Compressible Mixture . . . 2-4

2.3.2 Specific Heat for a Mixture ........ 2-5

3.0 MODEL DEVELOPNENT AND METHODOLOGY .............. . . . .

3.1 FLAMHABLE GAS AND DOHE AIRSPACE MODEL ........ 3-1

3.2 SY TANK FARM VENTILATION SYSTEM MODEL .......... 3-4

4.0 ASSUMPTIONS .......................... 4-1

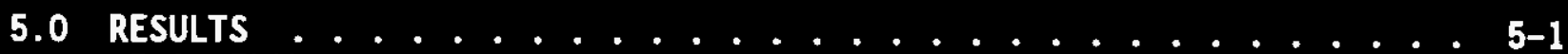

5.1 FLAMABLE-gAS PLUHE BURN . . . . . . . . . . 5-1

5.1.1 Steady-State Preconditions . . . . . . . 5-2

5.2 VENTILATION SYSTEM RESPONSE $\quad \ldots \ldots \ldots \ldots$

6.0 CONCLUSIONS AND RECONHENDATIONS ............... 6-1

7.0 REFERENCES .......................... 7-

\section{TABLES}

1-1. Sumary of the Flammable Gas Watch List Tanks . . . . . . . . . . 1-2

2-1. Chemical Reactions for the Flammable-Gas-Plume-Burn Analyses . . 2-2

3-1. Computational Variables Solved for Each Node During the

Fl ammable-Gas Plume Burn Analyses . . . . . . . . . . 3-2

3-2. Initial Volume (Holar) Percent for Composition of

Fl anmable-Gas plume .................. 3-3

5-1. Transient Intervals and Time Steps for the

5-2. Maximum Pressure and Maximum Differentiai Pressure Hithin Dome

Airspace Caused by a Flammable-Gas Plume Burn......... 5-2

5-3. Maximum Hach Numbers Predicted During Flanmable-Gas Plume Burn . . 5-3

5-4. Maximum Pressure and Maximum Differential Pressure for the

SY Tank Inlet and SY Tank Farm Exhaust HEPA Filters ....... 5-5 
FIGURES

2-1. Constant-Pressure Specific Heat vs Temperature for Various

Chemical Species... . . . . . . . . . . . . . . . . 2-7

3-1. Representative View of Waste Tank SY-101 and the SY Tank Farm

Ventilation System ...................... 3-5

3-2. Cross Section of Done Airspace. . . . . . . . . . . . . . . . 3-6

3-3. Finite-Element Mesh for Dome Airspace and Flammable-Gas

Plume Pocket. . . . . . . . . . . . . . . . . . . 3-7

3-4. Enlargement of the Flammable-Gas Plume Pocket and Surrounding

Area Showing Structure of the Finite-Element Mesh and Nodalization 3-8

3-5. SY Tank Farm Ventilation System (Finite Volumes). . . . . . . . 3-9

5-1. Steady-State Velocity $(\mathrm{m} / \mathrm{s})$ Vectors for Done Airspace . . . . . . 5-7

5-2. Steady-State Speed (m/s) Contours for Dome Airspace. . . . . . . 5-8

5-3. Steady-State Temperature $\left({ }^{\circ} \mathrm{K}\right)$ Contour for Dome Airspace . . . . . 5-9

5-4. Maximum Dome Pressure vs Time for Nodes 18 or 40 for Various

Volumes of Flaminable Gas and Number of Reactions ......... 5-10

5-5. Maximum Differential Pressure vs Time for Nodes 18 or 40 for

Various Volumes of Flanmable Gas and Number of Reactions . . . . . 5-11

5-6. Transient Pressure $(t=0.0025 \mathrm{~s})$ for $150-\mathrm{ft}^{3}$ Flammable-Gas Plume

Burn (4 Reactions). . . . . . . . . . . . . . . . . 5-12

5-7. Transient Pressure ( $t=0.0050 \mathrm{~s})$ for $150-\mathrm{ft}^{3}$ Flammable-Gas plume

Burn (4 Reactions) ................... . . . . . . . . . .

5-8. Transient Pressure $(t=0.0075 \mathrm{~s})$ for $150-\mathrm{ft}^{3}$ Flanmable-Gas Plume

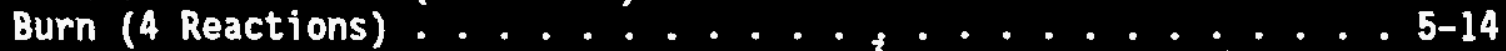

5-9. Transient Pressure $(t=0.0100 s)$ for $150-\mathrm{ft}^{\frac{3}{3}}$ Flammable-Gas plume

Burn (4 Reactions) ...................... 5-15

5-10. Transient Pressure ( $t=0.0125 s)$ for $150-\mathrm{ft}^{3}$ Flamable-Gas Plume

Burn (4 Reactions) . . . . . . . . . 5-16

5-11. Transient Temperature $\left({ }^{\circ} \mathrm{K}\right)(\mathrm{t}=0.05 \mathrm{~s})$ for $300-\mathrm{ft}^{3}$ Flammabie-Gas

Plume Burn (4 Reactions).

5-12. Transient Temperature $(K)(t=0.50 \mathrm{~s})$ for $300-\mathrm{ft}^{3}$ Flammable-Gas

Plume Burn (4 Reactions). . . . . 5-18

5-13. Transient Temperature $\left({ }^{\circ} K\right)(t=1.0 s)$ for $300-\mathrm{ft}^{3}$ Flammable-Gas

Plume Burn (4 Reactions).

5-14. Transient Temperature $\left({ }_{K}\right)(t=2.0 s)$ for $300-\mathrm{ft}^{3}$ Fiamable-Gas

Plume Burn (4 Reactions). ................. 5-20

5-15. Transient Temperature $(k)(t=3.0 s)$ for $300-\mathrm{ft}^{3}$ Fiamable-Gas

Plume Burn (4 Reactions). . . . . . . . . . . . . . 5-21

5-16. Transient Temperature $\left({ }^{6}\right)(t=4.0 s)$ for $300-f^{3}$ Flaimabie-Gas

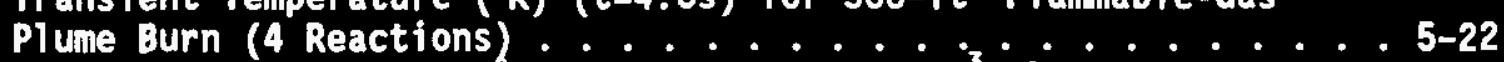

5-17. Transient Temperature $(K)(t=5.0 s)$ for $300-\mathrm{ft}^{3}{ }^{\circ}$ Fiamable-Gas

Plume Burn (4 Reactions).

5-18. Transient Temperature ( $K)(t-5.0 s)$ with Reset Range for $300-f^{3}$

Flammable-Gas Plume Burn (4 Reactions) : . . . . . . . . 5-24

5-19. Transient Velocity $(\mathrm{m} / \mathrm{s})$ Vectors $(t=5.0)$ for $300-\mathrm{ft}^{3}$

Flanmable-Gas Plume Burn (4 Reactions) . . . . . . . . . . 5-25

5-20. Transient Speed $(\mathrm{m} / \mathrm{s})$ Contour $(\mathrm{t}=5.0)$ for $300-\mathrm{ft}^{3}$

Flanmable-Gas Plume Burn (4 Reactions) . . . . . . . . . . 5-26

5-21. Ventilation System Transient Pressure vs Time for

$75 \mathrm{ft}^{3}$ Flammable-Gas Plume Burn (1 Reaction). . . . . . . . 5-27

5-22. Venti]ation System Transient Pressure vs Time for

75-ft ${ }^{3}$ Flanimable-6as Plume Burn (2 Reactions) . . . . . . . . 5-27

5-23. Venti]ation Systen Transient Pressure vs Time for

75- $\mathrm{ft}^{3}$ Flanmable-Gas Plume Burn (4 Reactions) 
WHC-SD-WM-ER-515, Rev. 0

5-24. Ventilation System Transient Pressure vs Time for 150- $\mathrm{ft}^{3}$ Flanmable-Gas Plume Burn (4 Reactions) . . . . . . . . . 5-28

5-25. Ventilation System Transient Pressure vs Time for 300-ft ${ }^{3}$ Flammable-Gas Plume Burn . . . . . . . . . . . . . . 5-29

5-26. Ventilation System Transient Pressure vs Time for 300-ft ${ }^{3}$ Flanmable-Gas Plume Burn (4 Reactions) . . . . . . . . 5-29

\section{APPENDIXES}

A. VALIDATION OF CHENICAL REACTION CAPABILITIES OF FIDAP . . . . . . . A-1

B. LISTING OF SUBROUTINE USRSPH - SPECIFIC HEAT OF IIXTURE. . . . . . . B-1

C. HMS/TRAC CONBUSTION PARANETERS. . . . . . . . . . . . . . . c-1

D. MASS FRACTIONS AS INPUT TO FIDAP

FOR FLAMMABLE-GAS PLUNE BURN ANALYSIS. . . . . . . . . . . . . D-1

E. INPUT AND RESULT FILES FOR FLANMABLE-GAS PLUNE BURN ANALYSES. . . . . E-1

\section{TABLES IN APPENDIXES}

Table A-1. Comparison of Hand Calculations and FIDAP Results . . . . . A-3

Table A-2. Comparison of FIDAP and Bureau of Mine Results for a Mixture of 10 Percent Hydrogen and 10 Percent Nitrous Oxide in Air . A-4

Table D-1. Mass Fractions as Input to FIDAP for Flammable-Gas Plume Burn . . . . . . . . . . . . . . . . . . . . . D-2

Table E-1. Sumary of Input and Result Files for Flammable-Gas Plume Burn and Ventilation-System Response Analyses . . . . . . E-2

\section{FIGURES IN APPENDIXES}

Figure A-1. Bureau of Mines Test Chamber . . . . . . . . . . . . . A-5

Figure A-2. Axi-Symetric Finite Element Mesh Representation for Bureau of Mines Test Chamber ............. A-6

Figure A-3. Comparison of Pressure vs Time as Predicted by FIDAP and Measured by BOH for a Flammable-Gas Burn of 10 Percent $\mathrm{H}_{2}$ and $\mathrm{N}_{2} \mathrm{O}$ in Air.................... A-7 


\section{Explanatory Notes}

1. The computer progran used to perform the flammable gas burn analyses allows the use of units from many different systems: English, CGS, and SI, etc. (user defined). When a simulation is performed using physical quantities and dimensions, it is very important to use a consistent set of units for the various quantities encountered during use. As a consequence, the figures produced during post-processing do not present the units. The readers are referred to the Nomenclature Table for the correct units.

2. U.S. Department of Energy regulations discourage the use of color figures. However, color copies of Figures 5-1 through 5-3 and 5-6 through 5-20 can be supplied on written request. 
WHC-SD-WM-ER-515, Rev. 0

Nomencl ature

(SI Units)

\begin{tabular}{||l|l|}
\hline \multicolumn{1}{|c|}{ Quantity } & \multicolumn{1}{c|}{$\mathrm{SI}$} \\
\hline \hline Length & meter $(\mathrm{m})$ \\
\hline Time & second $(\mathrm{s})$ \\
\hline Mass & Kilogram $(\mathrm{Kg})$ \\
\hline Temperature & Kelvin (K) \\
\hline Force & Newton (N) \\
\hline Energy & Joules (J) or (N-m) \\
\hline Gravitational Acceleration & $\mathrm{m} / \mathrm{s}^{2}$ \\
\hline Density & $\mathrm{kg} / \mathrm{m}^{3}$ \\
\hline Velocity & $\mathrm{m} / \mathrm{s}$ \\
\hline Pressure & $\mathrm{Pascal}\left(\mathrm{N} / \mathrm{m}^{2}\right)$ \\
\hline Dynamic Viscosity & $\mathrm{Pascal}-\mathrm{s}(\mathrm{Kg} / \mathrm{m}-\mathrm{s})$ \\
\hline Kinematic Viscosity & $\mathrm{m}^{2} / \mathrm{s}$ \\
\hline Specific Heat & $\mathrm{J} / \mathrm{kg}-\mathrm{K}$ \\
\hline Power & Watt $(\mathrm{J} / \mathrm{s})$ \\
\hline Heat Flux & $\mathrm{J} / \mathrm{m}^{2} \mathrm{~s}$ \\
\hline Volumetric Heat Source & $\mathrm{J} / \mathrm{m}^{3}-\mathrm{s}$ \\
\hline Heat Transfer Coefficient & $\mathrm{J} / \mathrm{m}^{2}-\mathrm{s}-\mathrm{K}$ \\
\hline Thermal Conductivity & $\mathrm{J} / \mathrm{m}-\mathrm{s}-\mathrm{K}$ \\
\hline Thermal Diffusivity & $\mathrm{m}^{2} / \mathrm{s}$ \\
\hline Mass Diffusivity & $\mathrm{m}^{2} / \mathrm{s}$ \\
\hline Volume Expansion Coefficient & $1 / \mathrm{K}$ \\
\hline Reaction Rate (mass units) & $\mathrm{Kg} / \mathrm{m}^{2}-\mathrm{s}$ \\
\hline $\begin{array}{l}\text { Heat of combustion (mass } \\
\text { units) }\end{array}$ & $\mathrm{J} / \mathrm{Kg}$ \\
\hline gc & $1 \mathrm{Kg}-\mathrm{m} / \mathrm{N}-\mathrm{s}^{2}$ \\
\hline Stefan-Boltzman Constant & $5.6667 \mathrm{E}-8 \mathrm{~J} / \mathrm{s}-\mathrm{m}^{2}-\mathrm{K}^{4}$ \\
\hline Universal Gas Constant & $8314.34 \mathrm{~J} / \mathrm{Kgmole}-\mathrm{K}$ \\
\hline & \\
\hline
\end{tabular}


WHC-SD-WM-ER-515, Rev. 0

\section{1-SY-101 WASTE TANK AIRSPACE AND VENTILATION SYSTEN RESPONSE TO FLANTABLE GAS PLUME BURUS}

\subsection{INTRODUCT1ON}

\subsection{PURPOSE}

This report documents the results of a series of flammable- gas-plumeburn and transient-pressure analyses that were performed for Waste Tank 241-SY-101 and the associated SY tank farm ventilation system.

The subject analyses were performed to address issues concerning the effects of igniting a small volume of concentrated flammable gas just released from the waste as a plume before mixing with the dome airspace by local convection and turbulent diffusion could reduce the flammable gas concentration. Such a condition may exist as part of an in-progress episodic gas release (EGR) or gas plume event. The analys is goal was to determine the volume of flammable gas, that, if burned within the dome airspace, would result in a differential pressure, after propagating through the ventilation system, greater than the current high-efficiency-particulate-air-filter (HEPA) limit of $2.49 \mathrm{KPa}$ (10 inches of water or $0.36 \mathrm{psi}$ ) (WHC 1995).

Such a pressure wave could potentially rupture the inlet and outlet exhaust HEPA filters, leading to a release of radioactive contaminants to the environment.

\subsection{BACKEROUND}

Twenty-five nuclear waste storage tanks at the Hanford Site have been placed on the Flammable Gas Watch List because of measured or potential releases of flammable gas from the waste. Table 1-1 summarizes the 1 isting of the Flammable Gas Watch List tanks as of November 1995. Hopkins (1994) summarizes $\mathrm{Flammable} \mathrm{Gas} \mathrm{Watch} \mathrm{List} \mathrm{criteria} \mathrm{and} \mathrm{provides} \mathrm{additional}$ background information.

Tank SY-101 was used as the basis for the subject analyses for several reasons. First, tank SY-101 has had occurrences of EGR that exceeded the lower flammability limit (LFL) for short periods of time; second, as a result of these releases, tank SY-101 has been studied in great detail and has several validated ventilation system models available.

As documented by Hopkins (1994), the evaluation of a potential flammable gas burn must consider whether the gas is at a uniform concentration throughout the dome space or concentrated in a smaller region or gas pocket, 
WHC-SD-WM-ER-515, Rev. 0

as would occur during an in-progress EGR. For a flammable gas burn to occur the following conditions must be satisfied:

- Sufficient fuel (hydrogen $\left(\mathrm{H}_{2}\right)$, ammonia $\left(\mathrm{NH}_{3}\right)$, or methane $\left(\mathrm{CH}_{4}\right)$ )

- Sufficient oxidizer (oxygen $\left(\mathrm{O}_{2}\right)$ in the dome airspace and/or as nitrous oxide $\left(\mathrm{N}_{2} \mathrm{O}\right)$ from the gas release)

- An ignition source

- Conditions that would allow flame propagation to occur throughout the flammable gas volume.

Table 1-1. Summary of the Flammable Gas Watch List Tanks (As of November 1995).

\begin{tabular}{|c|c|c|c|}
\hline Number & Identifier & Number & Ident ifier \\
\hline 1 & $241-\mathrm{A}-101$ & 13 & $241-\mathrm{SX}-109$ \\
\hline 2 & $241-\mathrm{AX}-101$ & 14 & $241-\mathrm{SX}-110$ \\
\hline 3 & $241-\mathrm{AX}-103$ & 15 & $241-\mathrm{U}-103$ \\
\hline 4 & $241-\mathrm{S}-102$ & 16 & $241-\mathrm{U}-105$ \\
\hline 5 & $241-\mathrm{S}-111$ & 17 & $241-\mathrm{U}-107$ \\
\hline 6 & $241-\mathrm{S}-112$ & 18 & $241-\mathrm{U}-108$ \\
\hline 7 & $241-\mathrm{SX}-101$ & 19 & $241-\mathrm{U}-109$ \\
\hline 8 & $241-\mathrm{SX}-102$ & 20 & $241-\mathrm{AN}-103$ \\
\hline 9 & $241-\mathrm{SX}-103$ & 21 & $241-\mathrm{AN}-104$ \\
\hline 10 & $241-\mathrm{SX}-104$ & 22 & $241-\mathrm{AN}-105$ \\
\hline 11 & $241-\mathrm{SX}-105$ & 23 & $241-\mathrm{AW}-101$ \\
\hline 12 & $241-\mathrm{SX}-106$ & 24 & $241-\mathrm{SY}-101$ \\
\hline & & 25 & $241-\mathrm{SY}-103$ \\
\hline
\end{tabular}

Sufficient fuels are assumed to be available for a short time following a small EGR when the flammable gases are concentrated. Sufficient oxidizers are also assumed to be available as part of the release and/or as part of the tank atmosphere. As a conservative measure, because ignition has been judged to be an credible event (Powers 1993), the occurrence of an in-progress EGR is taken as the potential to initiate a flammable gas burn. Finally, the in-progress EGR plume is assumed to be released from the waste at a rate just high enough that the plume remains relatively intact and does not disperse throughout the dome airspace. As an additional conservative measure, the gas plume was assumed to be released from the waste as a spherical bubble, thus ensuring an optimum geometry for flame propagation. 
WHC-SD-WM-ER-515, ReV. 0

\subsection{TECHNICAL BASES}

\subsection{CODE DESCRIPTION}

The FIDAP* and GOTHIC** computer codes were used to model the inprogress EGR flammable gas burn in tank SY-101 and its associated SY tank farm ventilation system. These codes have been verified and validated for use at the Hanford Site for safety- and quality-affecting analyses (Heard 1994 and Wood 1994).

\section{1 .1 FIDAP}

The Fluid Dynamic Analys is Package (FIDAP) is a commercially available general-purpose computer program that uses finite element methods (FEM) to simulate many classes of single- or multi-phase compressible or incompressible flows, including heat transfer, and mass transport of chemical species $(\leq 15)$ in both non-reacting and reacting flows. The simulation can be either steadystate or transient and can model flows in complex arbitrary geometries that may be two dimensional, axi-symmetric, or three dimensional. Mixed coordinate and rotating systems are supported.

FIDAP can be thought of as a single integrated environment for the simulation of thermal-hydraulic problems. The program can be viewed as an integrated set of components and program modules designed to perform all aspects of the model generation and automatic meshing or paving, problem setup, solution, and post-processing phases of a flow and/or thermal analysis.

\section{1 .2 GOTHIC}

GOTHIC (Generation of Thermal Hydraulic Information for Containments) is a general-purpose finite volume thermal-hydraulic computer program for the design, licensing, safety, and operational analys is of nuclear power plant containment and confinement structures and components. This code has been used extensively for commercial nuclear power plants safety and licensing analyses, and has been verified against measured test data. GOTHIC Version 3.5 has been validated and verified for use at the Hanford Site (Wood 1994).

GOTHIC also includes an extensive set of lumped-parameter and finite volume models for engineered safety equipment and other operating equipment, including ducts and piping, pumps and fans, valves and doors, heat exchangers, vacuum breakers, spray nozzles, coolers and heaters, and volumetric fans. These components can be controlled by trips to simulate the automatic and operator-controlled events during a containment-system transient.

FIDAP is a registered trademark of Fluid Dynamics, Inc., Evanston, Illinois.

** GOTHIC is a registered trademark of the Electric Power Research Institute, $\mathrm{Pal}$ Alto, California. 


\subsection{CHEMICAL REACTION CAPABILITY}

The FIDAP computer code was used to simulate a series of multiple competing flammable-gas burn reactions. Table 2-1 summarizes the chemical reactions that were simulated. Appendix $A$ documents the exercises that were performed to provide additional validation of the chemical reaction capabilities of FIDAP.

Table 2-1. Chemical Reactions for the Flammable-Gas-Plume-Burn Analyses.

\begin{tabular}{|c|l|c|}
\hline$\#$ & \multicolumn{1}{|c|}{ Reaction } & \multicolumn{1}{|c|}{$\begin{array}{c}\text { Heats of Combustion } \\
\text { (Kcal/gm-mole fuel) }\end{array}$} \\
\hline 1 & $\mathrm{~N}_{2} \mathrm{O}+\mathrm{H}_{2} \rightarrow \mathrm{H}_{2} \mathrm{O}+\mathrm{N}_{2}$ & $77.4\left(\mathrm{H}_{2}\right)$ \\
\hline 2 & $2 \mathrm{NH}_{3}+3 \mathrm{~N}_{2} \mathrm{O} \rightarrow 3 \mathrm{H}_{2} \mathrm{O}+4 \mathrm{~N}_{2}$ & $105.1\left(\mathrm{NH}_{3}\right)$ \\
\hline 3 & $2 \mathrm{H}_{2}+\mathrm{O}_{2} \rightarrow 2 \mathrm{H}_{2} \mathrm{O}$ & $57.8\left(\mathrm{H}_{2}\right)$ \\
\hline 4 & $4 \mathrm{NH}_{3}+3 \mathrm{O}_{2} \rightarrow 6 \mathrm{H}_{2} \mathrm{O}+2 \mathrm{~N}_{2}$ & $75.7\left(\mathrm{NH}_{3}\right)$ \\
\hline
\end{tabular}

An Arrhenius-type of reaction based on mass concentrations (i.e., mass fractions) was modeled with FIDAP. FIDAP supports reactions based on chemical kinetic-controlled models, such as the Arrhenius Law, where the reaction rate is determined from chemical kinetic considerations involving the local concentrations of the reactants, and al so supports mixing-controlled reactions where the mixing action of the turbulent velocity field determines the rate of reaction. Both mass-fraction- (default-) and molar-concentration-based forms of both reaction rate models are supported. Simple one-step, competing, controlling, quenching, and multi-step chemical reaction models are supported. (Quench reactions can be used to predict the onset of ignition given knowledge of the upper and lower flammability limits of a given flammable gas mixture or to shut down a reaction when a retardant or inhibitor is present in the mixture at high enough concentration levels.)

The mass fraction form the Arrhenius Law-based reaction rate used for the gas burn analyses is shown by the following equation.

$$
R_{j l}=k_{j l}\left(T+T_{R \theta f}\right)^{B_{l}} \operatorname{EXF}\left[\frac{E_{l}}{\left(T+T_{R \theta f}\right)} \prod_{j=1}^{N} C_{j}^{n_{j l}}\right.
$$

where

$$
\begin{aligned}
& \mathrm{R}_{\mathrm{jl}}=\text { Reaction rate for species } \mathrm{j} \text { in reaction } 1\left(\mathrm{~kg} / \mathrm{m}^{3}-\mathrm{sec}\right) \\
& \mathrm{k}_{\mathrm{jl}}=\begin{array}{l}
\text { Reaction rate constant for species } \mathrm{j} \text { in reaction } 1\left(\mathrm{~kg} / \mathrm{m}^{3}-\mathrm{sec}-\right. \\
\left.{ }^{\circ} \mathrm{K}^{\mathrm{B}}\right) . \text { Where, }{ }^{\circ} \mathrm{K}^{\mathrm{B}} \text { is dependent on the temperature power. }
\end{array} \\
& \mathrm{B}_{\ell}=\begin{array}{l}
\text { Temperature power in reaction } 1 . \\
\text { analyses. Hence, the unit term }{ }^{\circ} \mathrm{K}^{\mathrm{B}} \text { (Set to zeduces to } 1 \text { and can be } \\
\text { dropped from the reaction rate constant.) }
\end{array}
\end{aligned}
$$


$E_{\ell}=$ Activation energy for reaction 1 divided by Universal Gas Constant ( $\left.{ }^{\circ} \mathrm{K}\right)$

$n_{j e}=$ Power index of reacting species $j$ in reaction 1 .

$N=$ Number of reacting species in reaction $1(N \leq 15)$

$T_{\text {Rof }}=$ Reference temperature $\left({ }^{\circ} \mathrm{K}\right)$. Where $\left(T+T_{\text {Rof }}\right)$ is an absolute temperature. If the analyses are already based on an absolute temperature scale (i.e., ${ }^{\circ} \mathrm{R}$ or ${ }^{\circ} \mathrm{K}$ ), $\mathrm{T}_{\text {Rof }}$ can be set to zero.

$c_{j}=$ Mass fraction of species $j$.

subject to the constraint

$$
\sum_{j=1}^{n} C_{j}=1.0
$$

For modeling the effects of heats of combustion resulting from species $j$, the following expression is used (mass fractions).

$$
Q_{j}=\Delta H_{j} R_{j}
$$

where $Q_{j}=$ Heat of reaction rate $\left(\mathrm{J} / \mathrm{m}^{3}-\mathrm{s}\right)$ for all reactions in which species $j$ is involved

$\Delta H_{j}=$ Heat of combustion of species $\mathrm{j}(\mathrm{J} / \mathrm{kg})$

$R_{j}=$ Combined (total) reaction rate of species $j\left(\mathrm{~kg} / \mathrm{m}^{3}-\mathrm{s}\right)$ obtained by summing over all the reactions $\ell$ in which species $j$ is present.

The total heat of reaction source term $\left(Q_{R}\right)\left(\mathrm{J} / \mathrm{m}^{3}-\mathrm{s}\right)$ for use within the conservation of energy equation is obtained by summing over all species $j$, where $1<j \leq 15$.

$$
Q_{R}=\sum_{j=1}^{J} Q_{j}
$$

\subsection{THERHOPHYSICAL PROPERTIES}

The large amount of heat released in combustion and the corresponding change in chemical composition of the mixture greatly affects the temperature response of the fluid and many aspects of the turbulent flow fields. While all fluid properties are affected by combustion, by far the largest effects result from the variation in density and the specific heat of the mixture. A proper simulation of turbulent combustion therefore requires that at least the dependence of mixture density and specific heat on temperature and mixture concentration be adequately modeled. 


\subsubsection{Density Formulation for Compressible Mixture}

Given the equation of state for a homogeneous (i.e., single-component) ideal gas $\left(P V=n R_{u} T\right.$ ), the formulation for density is derived as follows.

$$
\begin{aligned}
P V & =n R_{u} T \\
P V & =\frac{m}{M} R_{u} T \\
P & =\frac{m}{V} \frac{R_{u} T}{M} \\
P & =\rho \frac{R_{u} T}{M} \\
\rho & =\frac{P \cdot M}{R_{u} T}
\end{aligned}
$$

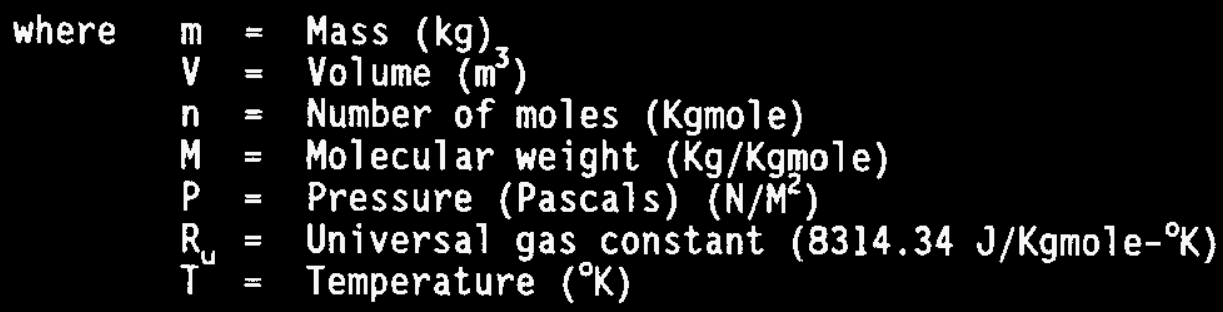

Equation 5 continues to hold for a mixture of $\mathbf{N}$ gases, with mass concentrations $C_{n}$, subject to the constraint

$$
\sum_{n=1}^{N} C_{n}=1
$$

and the relationship

$$
\frac{1}{M_{M i x}}=\sum_{n=1}^{N} \frac{C_{n}}{M_{n}}
$$

where $M_{M 1 x}$ is the blended molecular weight of the mixture and $M_{n}$ is the molecular weight of the $n^{\text {th }}$ component.

In FIDAP the equation of state for a gas mixture is expressed in a slightly different form. Equation 6 is rewritten in the form

Where the $N^{\text {th }}$ component is referred to as the carrier fluid. Equation 7 can be rewritten as 
WHC-SD-WM-ER-515, Rev. 0

$$
\begin{gathered}
C_{N}=1-\sum_{n=1}^{N-1} C_{n} \\
\left.\frac{1}{M_{M I X}}=\frac{1}{M_{N}}\left(1+\sum_{n=1}^{N} \frac{M_{N}}{M_{n}}-1\right) C_{n}\right)
\end{gathered}
$$

Equation 5 can be rearranged using Equation 9 to yield

$$
\rho=\frac{M_{N} P}{R_{u} T\left[1+\sum_{n=1}^{N-1}\left(M_{N} / M_{n}-1\right) C_{n}\right]}
$$

where $\rho$ is now the computed density of the mixture. Currently, FIDAP imposes the 1 imit $N=16$. This means a maximum of 15 species and 1 carrier fluid are permitted.

The computed molecular weight and density of the mixture are determined for every nodal point with in the computational domain and will vary depending on the local concentrations of the chemical species, pressure, and temperature.

\subsubsection{Specific Heat for a Mixture}

The most appropriate model for the specific heat of a mixture is

$$
C p_{M T X}=\sum_{n=1}^{N} C p_{n} C_{n}
$$

where $N=$ The total number of species present in the mixture (including the carrier fluid)

$\mathrm{CP}_{\mathrm{PIX}}=$ Constant-pressure specific heat of mixture $\left(\mathrm{J} / \mathrm{Kg}-{ }^{\circ} \mathrm{K}\right)$

$C_{P_{n}}=$ Constant-pressure specific heat $\left(J / \mathrm{Kg}^{-} \mathrm{K}\right)$ of species $n$

$C_{n} \quad=$ Mass fraction of species $n$ 
Where, the specific heat of each species $n\left(C P_{n}\right)$ is usually a function of temperature and is typically approximated in the form of a linear or higher order polynomial in terms of absolute temperature such as

$$
C p_{n}=A_{0}+A_{1} T+A_{2} T^{2}+\ldots+A_{n} T^{n}
$$

Values of specific heats, $C_{p}$, as a function of temperature for nitrous oxide, hydrogen, water vapor, ammonia, nitrogen, and oxygen, were obtained from the corresponding JANAF Thermochemical Tables (6) and fitted to polynomial forms up to the ninth order, as shown in Figure 2-1 for the temperature range 100 to $6,000{ }^{\circ} \mathrm{K}$. The specific heats $\left(C_{0}\right.$ and $C_{v}$ ) of the mixture are determined for each nodal point within the model as a function of local concentrations and temperature. The constant-pressure specific heat (Cp) of the mixture was implemented using Equation 11 via the user SUBROUTINE option for the SPECIFICHEAT command. Appendix B documents the SUBROUTINE USRSPH that was used to formulate and return the specific heat for the mixture at each nodal point.

The specific heat $C_{v}$ of the mixture was calculated internally (as shown by the following relationship) using values of the computed $C_{p}$ and molecular weight (Equation 9) of the mixture at each nodal point.

$$
C V_{M I X}=C p_{M I X}-R_{u} / M_{M I X}
$$

$$
\text { where } \begin{aligned}
& C V_{M I X}=\text { Specific heat for constant volume }\left(\mathrm{J} / \mathrm{kg}-{ }^{\circ} \mathrm{K}\right) \\
& C p_{M L X}=\text { Specific heat for constant pressure }\left(\mathrm{J} / \mathrm{kg}-{ }^{\circ} \mathrm{K}\right) \\
& \mathrm{R}_{u}=\text { Universal gas constant }\left(\mathrm{J} / \mathrm{kgmole} \mathrm{e}^{\circ} \mathrm{K}\right) \\
& M_{\text {MIX }}=\text { Blended molecular weight for mixture (kg/kgmole) from } \\
&
\end{aligned}
$$


Figure 2-1. Constant-Pressure Specific Heat vs Temperature for Various Chemical Species.

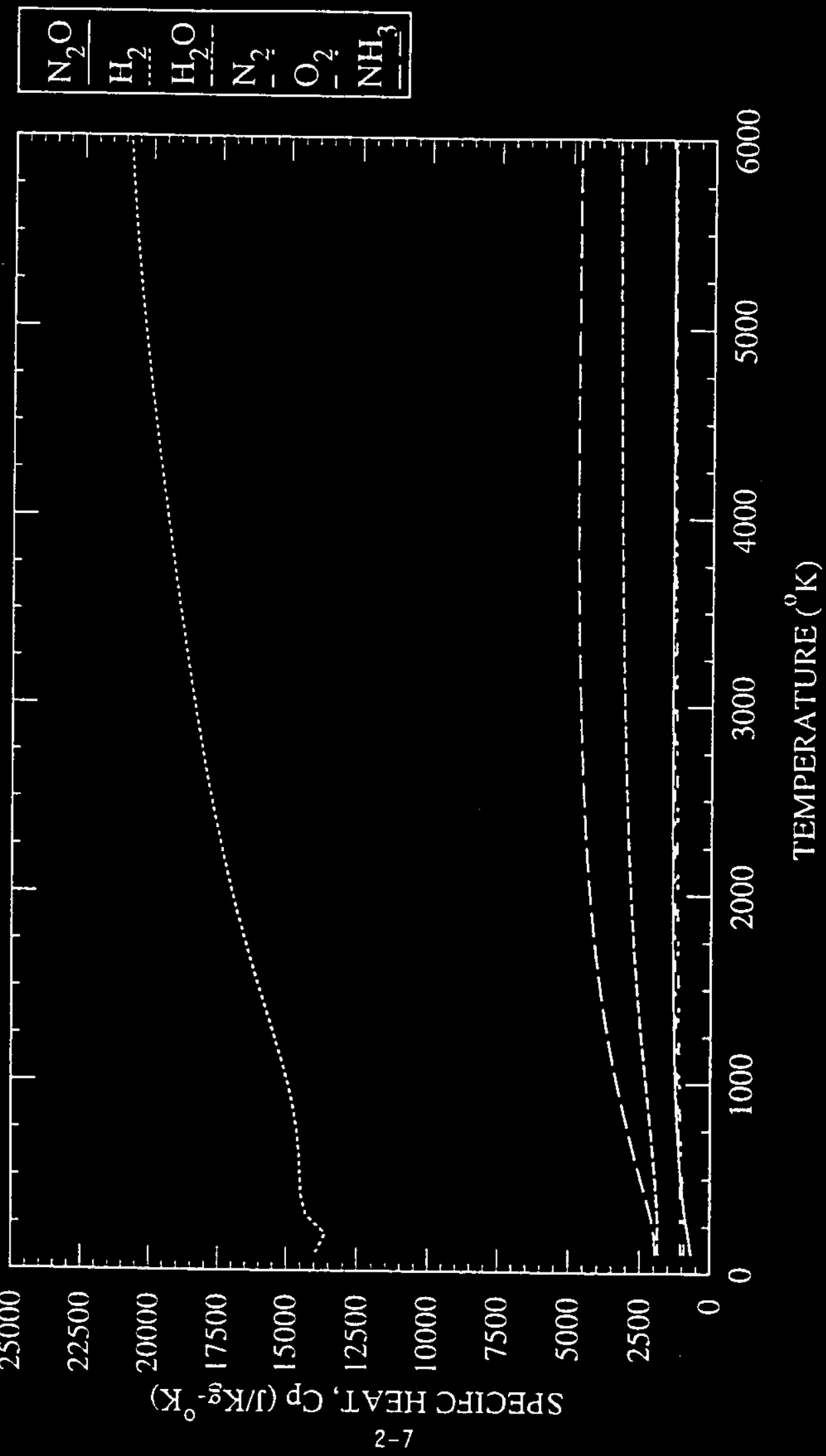




\subsection{MODEL DEVELOPNENT AND METHODOLOGY}

The FIDAP and GOTHIC models were numerically coupled by using a common pressure boundary condition physically associated with the intersection of the ventilation system (both inlet and exhaust legs) with the dome airspace. That is, FIDAP provided to GOTHIC the pressure histories for those elements adjacent to the physical locations corresponding to the inlet and outlet legs of the tank SY-101 ventilation system. GOTHIC used these values to compute the flow rates and corresponding transient pressures throughout the entire SY tank farm ventilation system.

Section 3.1 covers the flammable gas and tank airspace model that was developed for tank SY-101. Section 3.2 reviews the SY tank farm ventilation system model that was previously developed (Burke 1990) and was used with great success to model several of the large-scale EGR events. Section 3.2 also describes the modifications to the SY tank farm ventilation system model that were performed to incorporate the inlet riser and (HEPA) filter.

\subsection{FLANMABLE gAS AND DOME AIRSPACE HODEL}

The FIDAP computer code was used to perform a series of coupled thermal/hydraulic transient compressible fluid flow analyses by solving the conservation of mass, energy, momentum, and multiple species transport equations for a system involving multiple chemical reactions.

In addition to the transient pressure, the burn analyses solved for the individual species concentration, turbulent kinetic energy, turbulent kinetic energy dissipation rate, temperature, and velocity ( $X$ and $Y$ components) fields. Solutions for up to 12 variables were obtained for each node. Table 3-1 lists the computational variables that were solved for at each node.

Figure 3-1 is a general representative view of tank SY-101 showing the inlet and outlet (exhaust) riser, the dome airspace, and the associated tank farm ventilation system. Note the connections from the adjacent tanks. Figure 3-2 is a cross section of the dome airspace and shows the relative size and range of the simulated flammable gas plume pockets. The diameter of the flammable gas pocket was sized to be consistent with a $75-, 150-$, or $300-\mathrm{ft}^{3}$ gas release. The physical dimensions of the airspace were derived for a waste height of 10.16 (400 in.) and standard dimensions (Drawing H-2-71975) for a 75-ft-diameter double-shell tank and represents an enclosed volume of $41,220 \mathrm{ft}^{3}$. By varying the waste height or amount of sidewal1 freeboard, the tank SY-101 dome airspace model can be adapted to other waste tanks. 
WHC-SD-WM-ER-515, Rev. 0

Table 3-1. Computational Variables Solved for Each Node During the Flaimable-Gas Plume Burn Analyses.

\begin{tabular}{|c|c|l|}
\hline$\#$ & Variable & \multicolumn{1}{|c|}{ Description } \\
\hline \hline 1 & $U$ & X component of velocity \\
\hline 2 & $V$ & Y component of velocity \\
\hline 3 & $k$ & Turbulent kinetic energy \\
\hline 4 & $\epsilon$ & Turbulent kinetic energy dissipation rate \\
\hline 5 & $T$ & Temperature \\
\hline 6 & $P$ & Pressure \\
\hline 7 & $C_{1}$ & Concentration of Species $1\left(\mathrm{~N}_{2} 0\right)$ \\
\hline 8 & $C_{2}$ & Concentration of Species 2 $\left(\mathrm{H}_{2}\right)$ \\
\hline 9 & $C_{3}$ & Concentration of Species 3 $\left(\mathrm{H}_{2} \mathrm{O}\right)$ \\
\hline 10 & $C_{4}$ & Concentration of Species $4\left(\mathrm{~N}_{2}\right)$ \\
\hline 11 & $C_{5}$ & Concentration of Species $5\left(\mathrm{NH}_{3}\right)$ \\
\hline 12 & $C_{6}$ & Concentration of Species $6\left(\mathrm{O}_{2}\right)$ \\
\hline
\end{tabular}

Figures 3-3 and 3-4 present the finite-element mesh that was derived for the dome airspace and flammable gas pocket. Figure 3-4 is an enlargement of the mesh structure around the location of the simulated flammable gas pocket.

In FIDAP, the finite elements are input in groups. Within any single element group, all the elements must be of the same geometric type (i.e., QUADRILATERAL, TRIANGLE, BRICK (or HEX), WEDGE, or TETRAHEDRON) and must have the same number of nodes per element. All the elements shown in Figures 3-3 and 3-4 were designated as QUADRILATERALs with nine nodes corresponding to corner, side, and body centered locations. The meshing shown by figures 3-3 and 3-4 was derived from a paving algorithm developed as part of the Cubit mesh-generation project (Dosanjh 1995), based at Sandia National Laboratory, for the automatic meshing of highly unstructured geometries.

The inlet riser, dome airspace, gas pocket, and outlet riser were treated as separate element groups. Each element was allowed differing amounts of initial chemical concentration. For example, the inlet and outlet risers and the dome airspace were assigned initial species concentrations associated with the standard atmosphere (see Table 2-1), whereas the flammable gas plume pocket was assigned species concentrations consistent with a given release of flammable gases for various reactions.

Several different initial gas compositions were used to perform the analyses and are referred to as the 50/50 and WHC conservative. These mixtures reflect differing initial amounts of flammable gases. Table 2-1 compares the initial volume fractions for the above mixtures. Table 2-1 also 
compares several gas compositions (i.e., conservative and best estimate) that were developed by personnel at the Los Alamos National Laboratory (LANL) for use with their efforts in performing the safety assessment (LANL 1994) for the mixer-pump operations with tank 241-SY-101. Appendix D documents the corresponding mass fractions that were used as input to FIDAP.

The terms "50/50" and "WHC Conservative" refer to stoichiometric gas compositions that were developed to maximize the energy production by consuming all the fuel and oxidants and to bound the presence of 1 percent methane. (This was done to provide the beginning of a basis for conservatively bounding the remaining tanks on the Flammable Gas Watch List.) The 50/50 mixture is a stoichiometric gas composition for one reaction (Reaction 1, Table 2-1) involving only nitrous oxide and hydrogen and is referred to as the one reaction case. The WHC conservative mixture is a stoichiometric gas composition for two first two reactions (Reactions 1 and 2, Table 2-1) involving only nitrous oxide, hydrogen, and ammonia and is referred to as the two reaction case. The initial amounts (i.e., volume fraction) of nitrous oxide, hydrogen, and ammonia were chosen to exactly balance the first two chemical reactions as presented in Table 2-1. The remaining chemical reactions are assumed to involve reactions with atmospheric oxygen present within the dome airspace. When all four reactions presented by Table 2-1 are allowed to progress simultaneously, this is referred to as the four reaction case. The four reaction case is not stoichiometrically balanced.

Table 3-2. Initial Volume (Holar) Percent for Composition of Flammable-Gas Plume.

\begin{tabular}{|c|c|c|c|c|}
\hline Species & $50 / 50$ & WHC Cons. & LANL Cons. & $\begin{array}{c}\text { LANL Best } \\
\text { Est. }\end{array}$ \\
\hline \hline $\mathrm{N}_{2} \mathrm{O}$ & 48.0 & 51.2 & 27.20 & 24.71 \\
\hline $\mathrm{H}_{2}$ & 48.0 & 32.0 & 31.94 & 29.12 \\
\hline $\mathrm{H}_{2} \mathrm{O}$ & 4.0 & 4.0 & 2.40 & 2.40 \\
\hline $\mathrm{NH}_{3}$ & 0.0 & 12.8 & 14.95 & 10.95 \\
\hline $\mathrm{N}_{2}{ }^{*}$ & 0.0 & 0.0 & 23.51 & 32.82 \\
\hline $\mathrm{O}_{2}{ }^{*}$ & 0.0 & 0.0 & 0.00 & 0.00 \\
\hline TOTAL & 100.0 & 100.0 & 100.0 & 100.00 \\
\hline
\end{tabular}

To model reverse flows, different pressure boundary conditions (BCs) were applied to the inlet and outlet risers, resulting in a small differential pressure across the dome airspace. The pressure boundary conditions were chosen to establish a steady-state flow rate through the tank sufficient to

\footnotetext{
volume.

*Tank (standard) atmosphere; $N_{2}=79.05 \%$, by volume and $O_{2}=20.95 \%$ by
} 
WHC-SD-WM-ER-515, Rev. 0

exchange the 2-D volume at the same rate as the actual tank ventilation system. If the tank pressure exceeded the inlet riser boundary condition, for example, flow out the inlet rise would have occurred. A constant-velocitybased boundary condition could have established the same steady-state flow rate, but would not have reversed during an overpressure condition.

\subsection{SY TANK FARH VENTILATION SYSTEM MODEL}

A validated lumped-parameter ventilation system model is available for tank SY-101. The ventilation system model was originally developed using the FATHOMS (Burke 1990) computer program, which is the predecessor to the GOTHIC computer code.

GOTHIC was able to read the input file associated with the FATHOM-based ventilation system model and establish an equivalent lumped-parameter model. The lumped-parameter ventilation system has a flow area, length, volume etc. associated with each lumped mass node. Using this information, the lumpedparameter model was converted to a finite-volume model capable of tracking the pressure wave through the various volumes associated with the ventilation system.

Several additional modifications were made. They are:

- Addition of the inlet riser

- Addition of the inlet HEPA filter using vendor-supplied data to drive the loss coefficients

- Tank SY-101 volume changed to a pressure boundary condition capable of using pressure versus time values from FIDAP as input.

Figure 3-5 presents the SY tank farm ventilation system as modified by GOTHIC. Control volume 1 s and 2 represent waste tanks 241-SY-102 and 103, respectively. Control volumes $7 \mathrm{~s}$ and 13 represent the out let and inlet HEPA filter, respectively. A pressure boundary condition (2P, 3P, 4P, and 6P) of 14.7 psia was applied to the inlet of $\operatorname{tank} S Y-101,-102$, and -103 , as well as the fan discharge.

A pressure boundary condition (1P and 5P) that corresponds to the peak dome pressure at nodes 18 or 40 was applied to tank SY-101.

The ventilation system model presented in Figure 3-5 has been normalized to actual ventilation system operating data and was derived from the original FATHOMS model without change to any of the thermal/hydraulic parameters. As such, the presence of ventilation system control valves (i.e., dampers) has been modeled as pressure loss coefficients adjusted to give a nominal $500 \mathrm{cfm}$ flow rate through tank $S Y-101$ before the flammable-gas burn. 
WHC-SD-WM-ER-515, Rev. 0

Figure 3-1. Representative View of Waste Tank SY-101 and the SY Tank Farm Ventilation System.

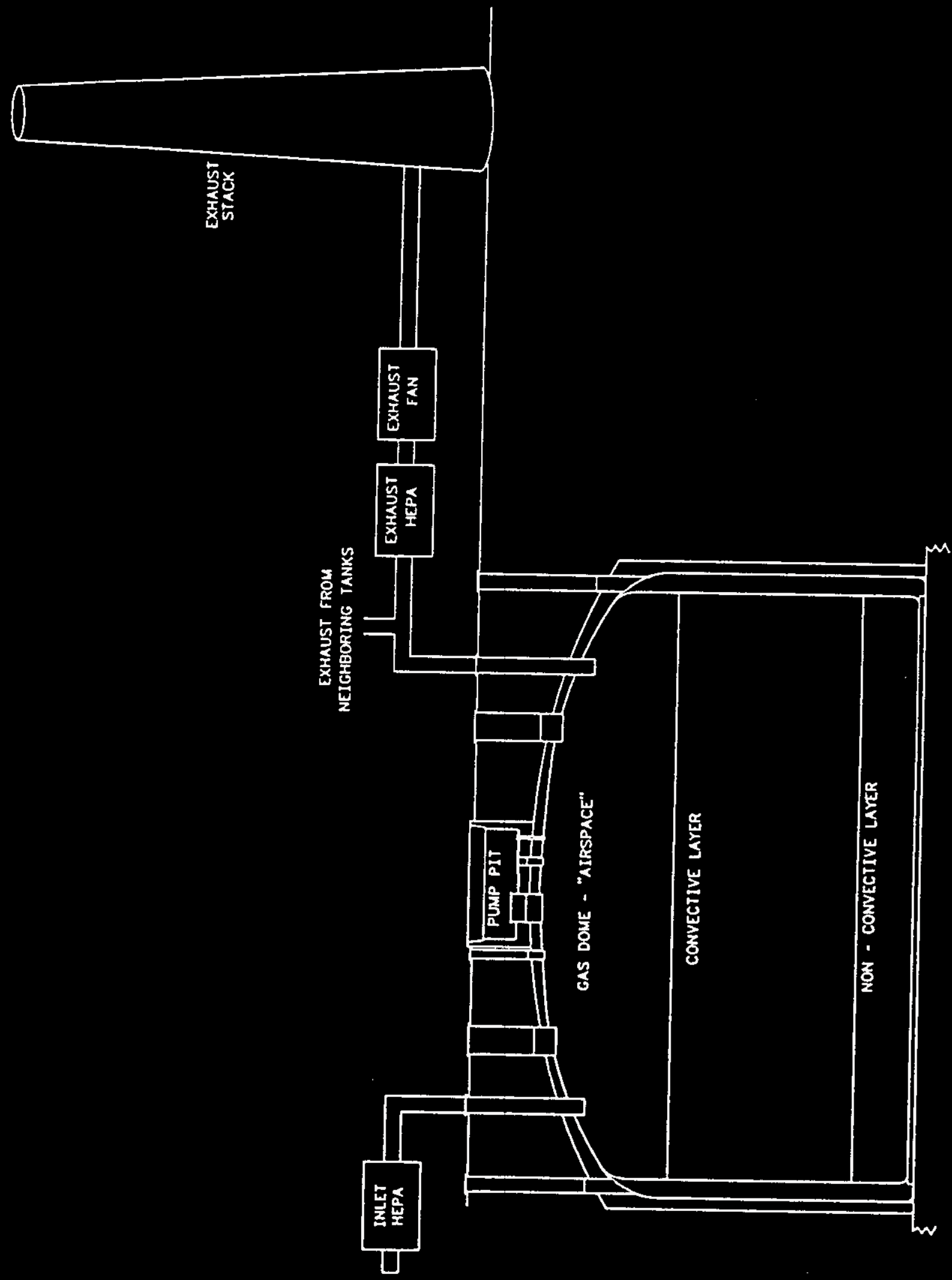


WHC-SD-WM-ER-515, Rev. 0

Figure 3-2. Cross Section of Dome Airspace.

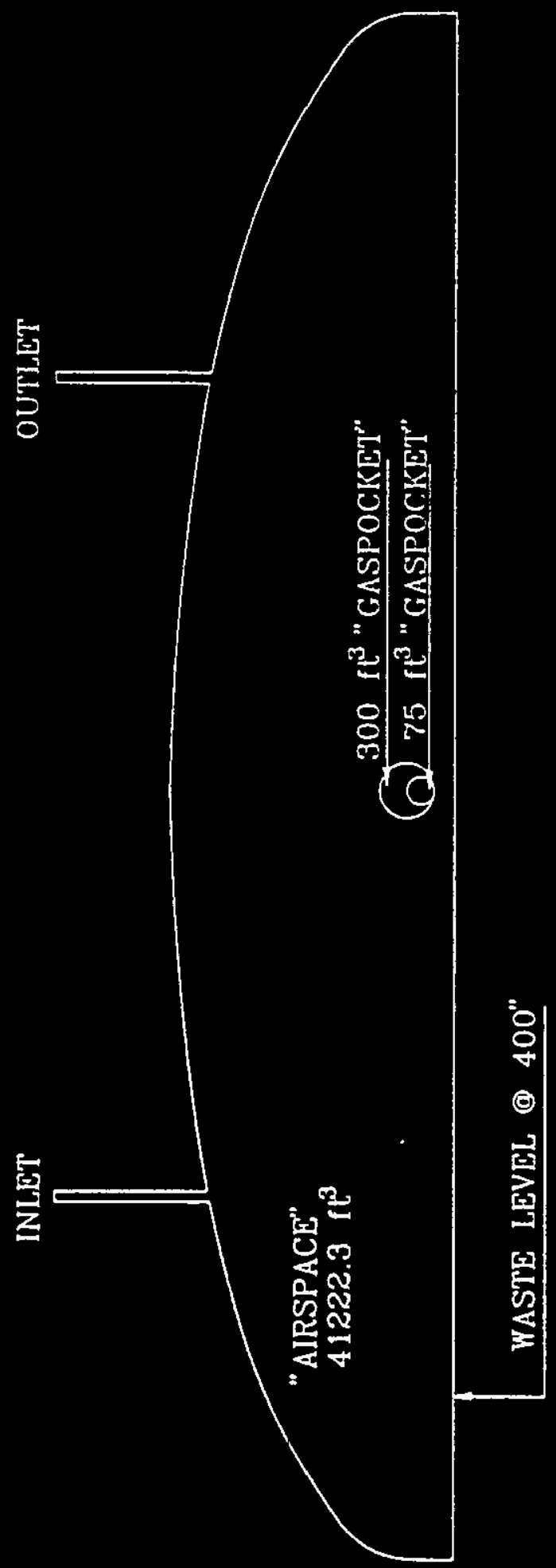


WHC-SD-WM-ER-515, Rev. 0

Figure 3-3. Finite-Element Mesh for Dome Airspace and Flammable-Gas Plume Pocket.

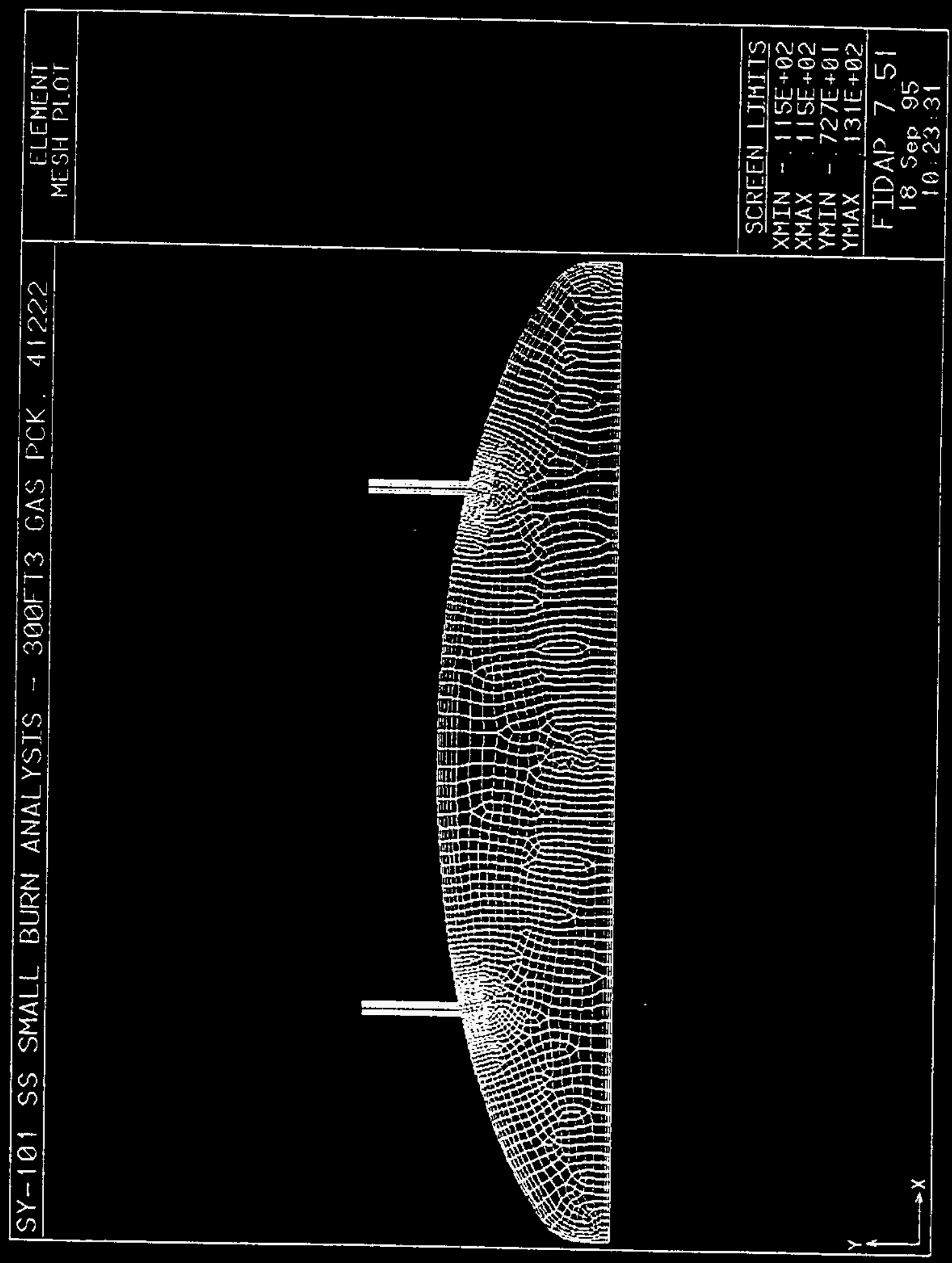


Figure 3-4. Enlargement of the Flammable-Gas Plume Pocket and Surrounding Area Showing Structure of the Finite-Element Mesh and Nodalization.

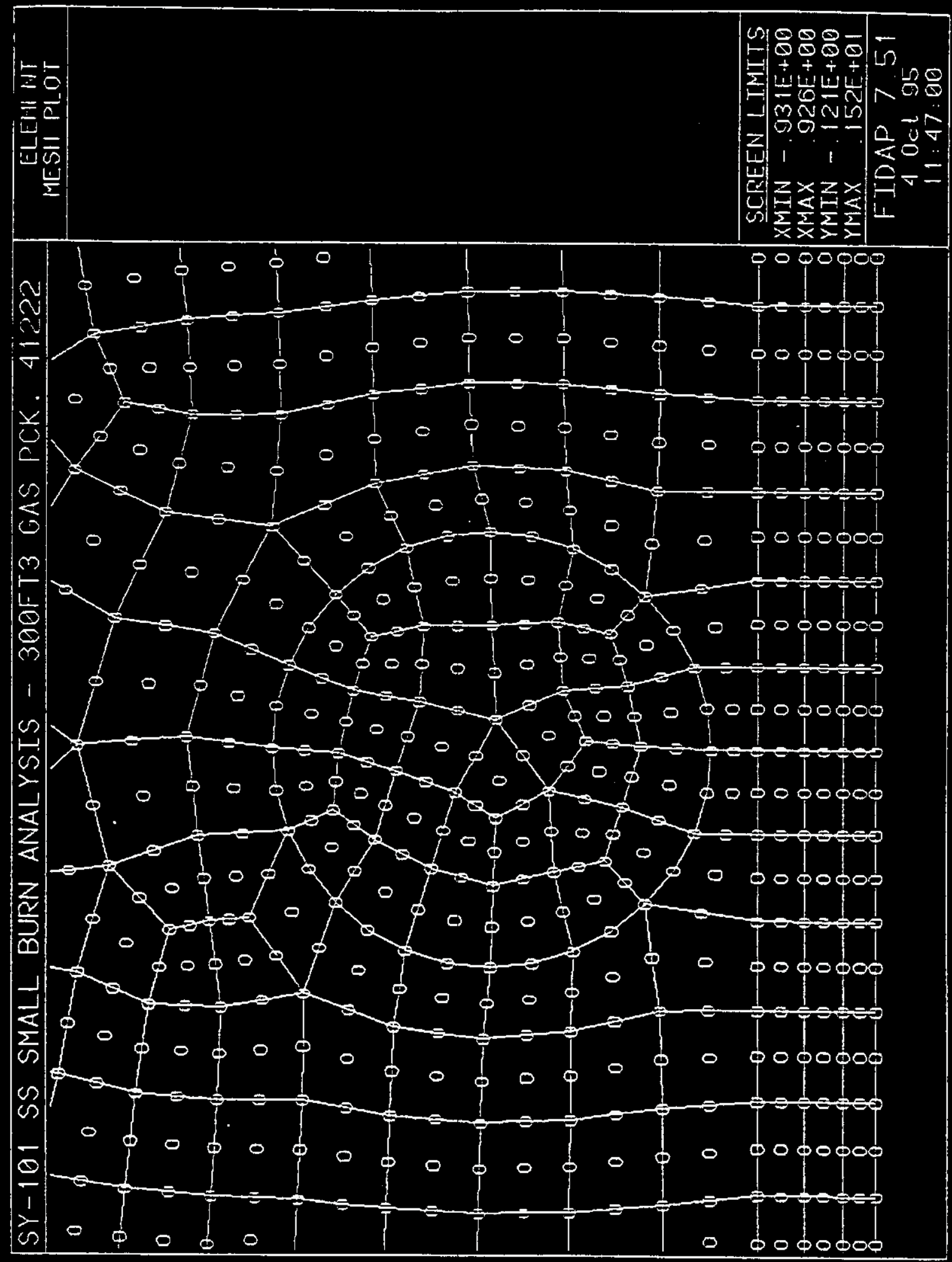


WHC-SD-WM-ER-515, Rev. 0

Figure 3-5. SY Tank Farm Ventilation System (Finite Volumes).

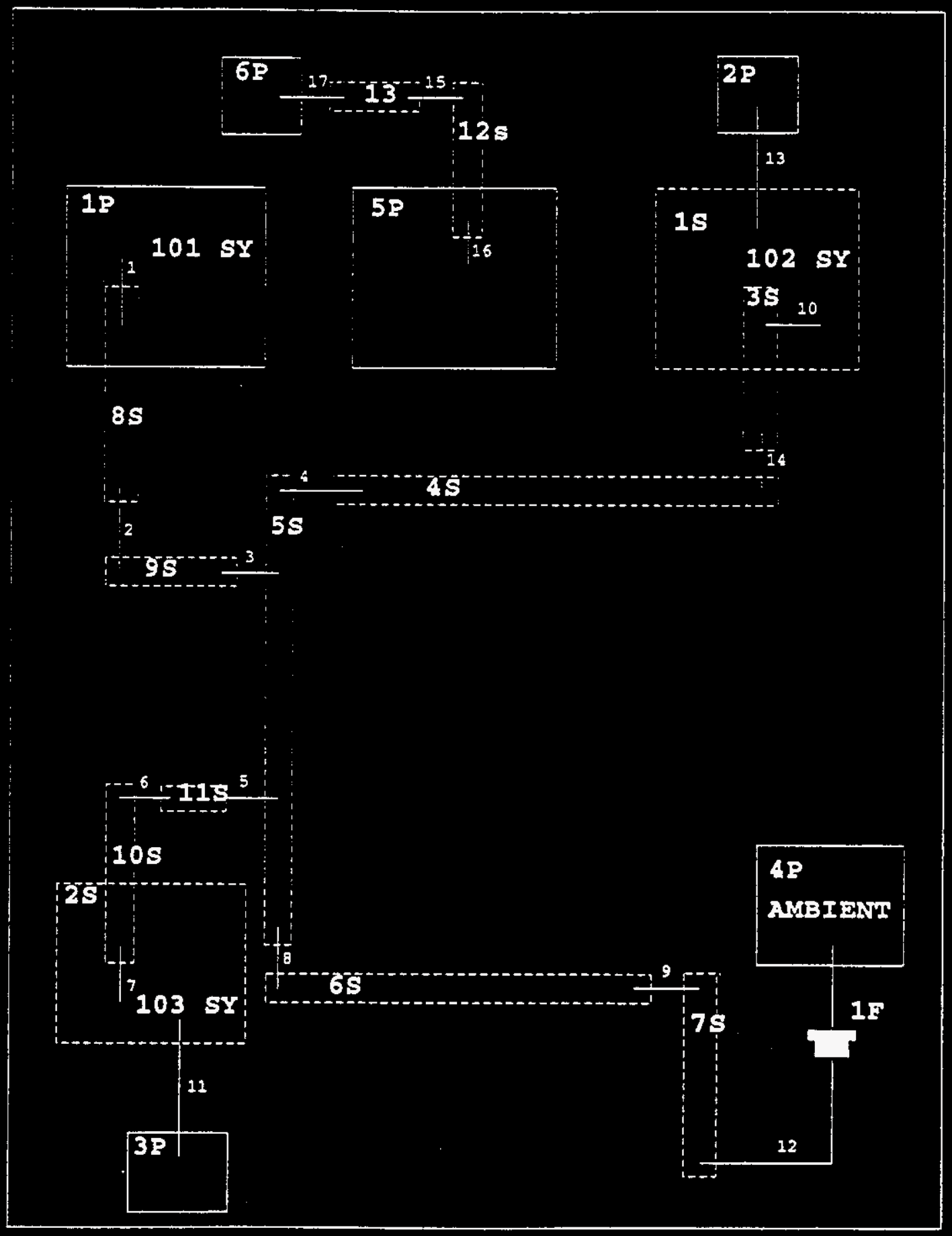




\subsection{ASSUMPTIOAS}

The following assumptions were used for the flammable-gas burn analyses.

- The tank SY-101 dome airspace was assumed to be a steady-state equilibrium condition before initiating the flammable gas burn.

- The above-waste or dome airspace volume was assumed to be $41,220 \mathrm{ft}^{3}$ corresponding to a waste height of $400 \mathrm{in.}$.

- For the purposes of this analysis, the flammable gas plume was assumed to be released from the surface of the waste centered within the dome airspace. Gas release and deflagration locations other than waste centered under the dome airspace are left to future analyses. However, it is expected that the pressure response of the ventilation system to gas burns centered directly under either the inlet or outlet risers will be more severe than for the waste-centered case discussed in this report.

- The flammable gas plume was assumed to be instantaneously released as a spherical volume of 75,150 , or $300 \mathrm{ft}^{3}$.

- The flammable-gas plume was assumed to remain intact and was not dispersed by local convection flow fields or turbulent diffusion until ignition occurs.

- Ignition was assumed to occur at time zero.

- The flammable-gas burn was assumed to be initiated by an ignition source (hot spot) centered within the gas pocket.

- The resulting water vapor was assumed to remain as vapor and not condense.

- The gas mixture was assumed to be compressible.

- Radiative heat transfer from the combustion flame was not assumed. A11 of the energy from the heat of reaction was assumed to be deposited within the individual reacting element.

- A one-step multi-species chemical kinetic model based on the Arrhenius Rate Law with competing reactions was assumed.

- An adiabatic heat transfer wall boundary was assumed to surround the dome airspace. No energy was transferred across tank walls, dome, or waste surface. Energy removal from the system was allowed via mass transport by the ventilation system.

- The flammable gas simulations were assumed to involve six gaseous species $\left(\mathrm{N}_{2} \mathrm{O}, \mathrm{H}_{2}, \mathrm{H}_{2} \mathrm{O}, \mathrm{N}_{2}, \mathrm{NH}_{3}\right.$, and $\left.\mathrm{O}_{2}\right)$. 
The following assumptions were used for the ventilation system pressure pulse analysis:

- The SY tank farm ventilation system was assumed to be in a steadystate equilibrium condition corresponding to an active fan model with a volumetric flow rate through tank SY-101 of $500 \mathrm{cfm}$.

- The dynamic response of the ventilation system was based on constant loss coefficients. The response of the system is assumed to be representative up to the point of HEPA filter failure. Additional modeling will be required to accurately describe system performance beyond the point of HEPA filter failure.

- The ventilation system control system (dampers) are assumed to be open, but with loss coefficients adjusted to obtain a volumetric flow rate through tank SY-101 of $500 \mathrm{cfm}$. 


\subsection{RESULTS}

The results of the flammable-gas plume burn and ventilation system response analyses are summarized in Sections 5.1 and 5.2 , respectively. The finite element analysis of any flow-field problem of realistic size produces an incredible amount of numerical data that in itself is very difficult to analyze. Almost all of the required information about the subject flammable-gas-burn analyses can be obtained from velocity vector, pressure, temperature, and chemical species concentration contour plots, as well as time history plots of selected variables at various nodes. Appendix $E$ documents the input and result files associated with both the flammable-gasburn and ventilation-system analyses. All the results presented in Sections 5.1 and 5.2, were obtained from the various FIDAP and GOTHIC result files using the graphical user interface (GUI) post-processing capabilities supplied with both codes.

\subsection{FLAMHABLE-gAS PLUME BURN}

The flammable-gas-plume burn analyses simulated five seconds of time airspace response. Each of the analyses consisted of a steady-state precondition followed by the transient flammable gas burn. Each transient was broken into three intervals with different time steps. Table 5-1 presents a breakdown of the intervals and corresponding time steps.

Table 5-1. Transient Intervals and Time Steps for the Flammable-Gas Plume Burn Analyses.

\begin{tabular}{|c|c|c|c|}
\hline Interval \# & Start $(s)$ & End(s) & Time Steps \\
\hline 1 & 0.0 & 0.01 & 0.0025 \\
\hline 2 & 0.01 & 0.05 & 0.010 \\
\hline 3 & 0.05 & 5.00 & 0.050 \\
\hline
\end{tabular}

The first interval was restarted from a steady-state equilibrium precondition that provided an initial guess of the turbulent flow fields and temperature distribution without chemical reactions for each of the three release volumes. The subsequent intervals were restarted using the endpoint results from the previous analysis.

Small time steps were required during the first interval to resolve the transient pressure wave assocjated with a rapid burn. Larger time steps were used in the remaining intervals as the pressure wave expanded outward and gradually diminished because of interactions with the dome and waste surfaces. 


\subsubsection{Steady-State Preconditions}

Because of the numerical difficulties associated with performing a transient compressible flow analysis with reacting flows, several steady-state equilibrium precondition analyses were performed. The steady-state analyses were used to provide an initial estimate of the flow fields and temperatures for use with the transient analyses.

Steady-state analyses were performed for the 75-, 150-, and 300-ft release volumes. Three separate analyses were required because the mesh pattern was slightly different because different diameters were used to simulate the various volumes of flammable gas. An exact nodal overlay was required to allow the corresponding transient cases to read the steady-state results.

Figures 5-1, 5-2, and 5-3 present representative velocity vector, speed and temperature pattern plots for a steady-state equilibrium precondition associated with a release of $150 \mathrm{ft}^{3}$ of flammable gas.

Comparisons between the three steady-state precondition cases show very close agreement. This provides assurances that a consistent bas is, representative of actual steady-state conditions within tank SY-101, was used to perform the transient analyses.

\subsubsection{Transient Results}

The results of the flammable-gas-plume-burn analyses within the dome airspace are summarized in Table 5-2 and presented in Figures 5-4 and 5-5. Table 5-2 presents the maximum pressure and maximum differential pressure for either Node 18 or Node 40. These nodes define the computational elements that are positioned at the intersection of the inlet and exhaust riser with the dome airspace (see Figure 3-3). The differential pressure was calculated assuming the initial pressure was 14.7 psia.

Table 5-2. Maximum Pressure and Maximum Differential Pressure Within Dome Airspace Caused by a Flamnable-Gas Plume Burn.

\begin{tabular}{|c|c|c|c|}
\hline & \multicolumn{3}{|c|}{$\begin{array}{c}\text { Maximum Pressure (psia) and Maximum } \\
\text { Differential Pressure (psia) } \\
\text { Number of reactions }\end{array}$} \\
\hline $\begin{array}{c}\text { Flammable gas } \\
\text { volume } \\
\left(\mathrm{ft}^{3}\right)\end{array}$ & 1 & 2 & 4 \\
\hline 75 & $15.38 / 0.68$ & $15.3 / 0.73$ & $15.29 / 0.59$ \\
\hline 150 & -- & -- & $16.18 / 1.48$ \\
\hline 300 & -- & $16.95 / 2.27$ & $17.27 / 2.57$ \\
\hline
\end{tabular}

\footnotetext{
"Initial pressure, $P_{0}=14.7$ psia.
} 
Figures 5-4 and 5-5 present the transient maximum and differential pressures predicted for Nodes 18 and 40, respectively, for various flammable gas volumes and numbers of simulated reactions. Figures 5-4 and 5-5 are based on flammable gas releases of 75,150 , and $300 \mathrm{ft}^{3}$ for 1,2 , or 4 reactions. The effects of increasing the flammable gas volume are clearly evident. The number of simulated reactions has a smaller effect.

The results presented in Table 5-2 and Figures 5-4 and 5-5 are constrained for simulations with Mach numbers of less than 1.0. Table 5-3 presents the maximum Mach numbers predicted for the various analysis. In a11 cases, the predicted maximum Mach number is less than 1.0 .

Table 5-3. Naximum MACH Numbers Predicted During Flammable-Gas Plume Burn. (FIDAP Constraint Ma $<1$ )

\begin{tabular}{|c|c|c|c|c|}
\hline & \multicolumn{3}{|c|}{ Maximum MACH Numbers } \\
\hline $\begin{array}{c}\text { Flammable Gas } \\
\text { Volume } \\
\left(\mathrm{ft}^{3}\right)\end{array}$ & $\begin{array}{c}\text { Number } \\
\text { of } \\
\text { Reactions }\end{array}$ & $\begin{array}{c}\text { Airspace } \\
+ \text { Gas Pocket }\end{array}$ & Node 18 & Node 40 \\
\hline 75 & 1 & 0.31 & 0.13 & 0.14 \\
\hline 75 & 2 & 0.32 & 0.14 & 0.15 \\
\hline 75 & 4 & 0.30 & 0.12 & 0.13 \\
\hline 150 & 4 & 0.38 & 0.23 & 0.23 \\
\hline 300 & 2 & 0.41 & 0.29 & 0.30 \\
\hline 300 & 4 & 0.42 & 0.32 & 0.32 \\
\hline
\end{tabular}

The results presented by Figure 5-4 were used as input to the GOTHIC code for the ventilation system response analyses.

A flammable-gas plume burn produces a pressure wave that propagates radially outward from the origin of the burn. The transient pressures presented by Figures 5-4 and 5-5 show a classical rise and fall in pressure caused by compression and rarefaction as the pressure wave front passes.

Figures 5-6 through 5-10 present a representative time sequence of pressure contour plots for the entire dome airspace and gas pocket. The time increment is 0.0025 second and ranges from 0.0025 second to 0.0125 second. Figures 5-6 through 5-10 were obtained for a 150- $\mathrm{ft}^{3}$ flammable-gas burn for 4 simulated reactions. Figures 5-6 through 5-10 clearly show the compression wave expanding outward and reflecting from the roof of the dome.

The pressure oscillations noted with in Figures 5-4 and 5-5 gradually dampen and diminish because interactions with the interior tank side walis, dome surface, waste surface, and mass transport (removal) from the system via the ventilation systems. 
Figures 5-11 through 5-17 present a time history sequence of the temperature contour plots for a $300 \mathrm{ft}^{3}$ flammable gas burn with 4 simulated reactions. The time sequence is: $0.05,0.50,1.0,2.0,3.0,4.0$, and 5.0 seconds. Notice that the temperature range is fixed from 300 to $2,100{ }^{\circ} \mathrm{K}$. Hence, as the temperature decreases with time the detail is washed out. Figure 5-18 presents the same data as Figure 5-17 (i.e., temperature profile at 5.0 seconds), but with the range reset based on the maximum and minimum temperatures within the computational domain. Figure 5-18 now shows much more detail than Figure 5-17. Two distinct temperature regions, associated with turbulent flows are now evident. Closer inspection reveals the cooler inlet flow pattern reestablishing and some hot combustion products being swept out of the dome airspace.

Figures 5-19 and 5-20 present the vector velocity and speed (i.e., velocity magnitude) contour plots at 5.0 seconds for a $300-\mathrm{ft}^{3}$ flammable-gas burn. These figures support the swirl patterns inferred by the previous temperature contour plots. Several large-scale circulation cells are evident. Smaller circulation cells, most notably in the dome corners near the waste surface, also are evident. Figures 5-19 and 5-20 can be compared to corresponding steady-state results in Figures 5-1 and 5-2.

A flammable-gas plume burn has a significant impact on the pressure flow and temperature distribution within a waste tank.

It must be emphasized that the flammable gas burns discussed in this report do not address the gas release rate from the waste. The subject analyses are restricted to assuming that a given volume of flammable gas was released and maintains an optimum geometry for deflagration. If the initial gas release event (GRE) is large enough, the presence of additional mass within the dome airspace will cause a pressure rise. The net pressure versus time effect will be similar to the response to a pressure wave caused by a flammable-gas burn. The magnitude of the pressure wave will be highly dependent on the gas release rate and whether deflagration occurred at some later time.

\subsection{VENTILATION SYSTEM RESPONSE}

The results of the ventilation system response analyses are summarized in Table 5-4 and shown graphically in Figures 5-21 through 5-26.

Table 5-4 presents the maximum pressure and maximum differential pressure caused by a series of flammable gas plume burns for both the inlet HEPA filter to tank SY-101 and the outlet exhaust HEPA filter to the SY tank farm ventilation system.

Figures 5-21 through 5-26 present the transient pressures profile predicted for the inlet and outlet exhaust filters. Figures 5-21, through 5-23 were derived from results based on a 75- $\mathrm{ft}^{3}$ fiammable-gas burn for 1,2 , and 3 simulated reactions, respectively. Figure 5-24 was obtained from the results for a $150-\mathrm{ft}^{3}$ flammable-gas burn and 4 reactions. Figures $5-25$ and 5-26 were obtained from a 300-ft flammable gas plume burn for 2 and 4 reactions, respectively. 
WHC-SD-WM-ER-515, Rev. 0

It must be emphasized that the results presented within this report reflect only tank SY-101 and the SY tank farm ventilation system. Other tanks with different dome airspace volumes, gas composition, ventilation system configuration, etc., will respond differently to a flammable-gas plume burn. It is expected that a small flammable-gas plume burn in tanks without an active ventilation system will exceed the pressure limit for both the inlet and outlet HEPA filters. This is especially true for most single-shell tanks, with the notable exception of the SX tank farm, where the ventilation system usually consists of one or two HEPA filters on smal1-(4-in.) diameter risers and relies on natural breathing resulting from barometric pressure changes. This can be compared to double-shell tanks with two large-(12-in.) diameter risers.

Table 5-4. Maximum Pressure and Maximum Differential Pressure for the SY Tank Inlet and SY Tank Farm Exhaust HEPA Filters.

\begin{tabular}{|c|c|c|c|c|}
\hline \multirow[b]{2}{*}{$\begin{array}{l}\text { HEPA filter } \\
\text { location }\end{array}$} & \multirow[b]{2}{*}{$\begin{array}{l}\text { Flammable gas } \\
\text { volume } \\
\left(\mathrm{ft}^{3}\right)\end{array}$} & \multicolumn{3}{|c|}{$\begin{array}{c}\text { Maximum pressure* (psia) and Maximum } \\
\text { Differential Pressure (psia) } \\
\text { (Number of Reactions) }\end{array}$} \\
\hline & & 1 & 2 & 4 \\
\hline Inlet & 75 & $15.90 / 1.20$ & $16.00 / 1.30$ & $15.75 / 1.05$ \\
\hline Out let & 75 & $14.78 / 0.08$ & $14.78 / 0.08$ & $14.76 / 0.06$ \\
\hline Inlet & 150 & - & -- & $17.30 / 2.60$ \\
\hline Outlet & 150 & -- & -- & $14.97 / 0.27$ \\
\hline Inlet & 300 & - & $18.82 / 4.12$ & $19.40 / 4.70$ \\
\hline Outlet & 300 & - & $15.23 / 0.55$ & $15.32 / 0.62$ \\
\hline
\end{tabular}

It must be emphasized that the results presented in Figures 5-21 through 5-26 reflect the dynamic response of the SY tank farm ventilation system based on constant loss coefficients. The pressure oscillations associated with the inlet HEPA filters, as shown in Figures 5-21 through 5-26, represent the backand-forth reflection of the compression wave between the downstream inlet HEPA filter face and the pressure boundary condition associated with the dome airspace. The pressure oscillations gradually dampen and fade away because of the energy loss terms associated with frictional effects and geometric form changes.

The response of the SY tank farm ventilation system is assumed to be representative up to the point of exceeding the maximum differential pressure limit of the HEPA filters. Filter failure, with a corresponding change in the

\footnotetext{
${ }^{\star}$ Ambient Pressure $P=14.7$ psia.

${ }^{* *}$ HEPA $\triangle$ P 7 imit $=0.36$ psia $(10$ inches $w . g ., 2.49 \mathrm{KPa})$.
} 
loss coefficient, was not modeled. The purpose of this analys is was to determine the volume of flammable gas, that if ignited, could result in failure of the HEPA filters.

The results indicate that the pressure difference limit of 0.36 psia for the SY-101 tank inlet HEPA filter will be exceeded for a flammable-gas plume burn of $75 \mathrm{ft}^{3}$ or larger. Flammable-gas plume burns of less than $75 \mathrm{ft}^{3}$ were not investigated.

The results indicate that the pressure difference limit for the SY tank farm outlet HEPA filter will not be exceeded for flammable-gas plume burns of 75 and $150 \mathrm{ft}^{3}$. However, a flammable-gas plume burn of $300 \mathrm{ft}^{3}$ will exceed the pressure-difference limit. A simple first-order estimate using linear interpolation indicated that the HEPA pressure-difference failure threshold, $0.36 \mathrm{psgia}$, is reached for a flammable gas plume burn of approximately $190 \mathrm{ft}^{3}$. This remains to be confirmed. 
WHC-SD-WM-ER-515, Rev. 0

Figure 5-1. Steady-State Velocity $(\mathrm{m} / \mathrm{s})$ Vectors for Dome Airspace.

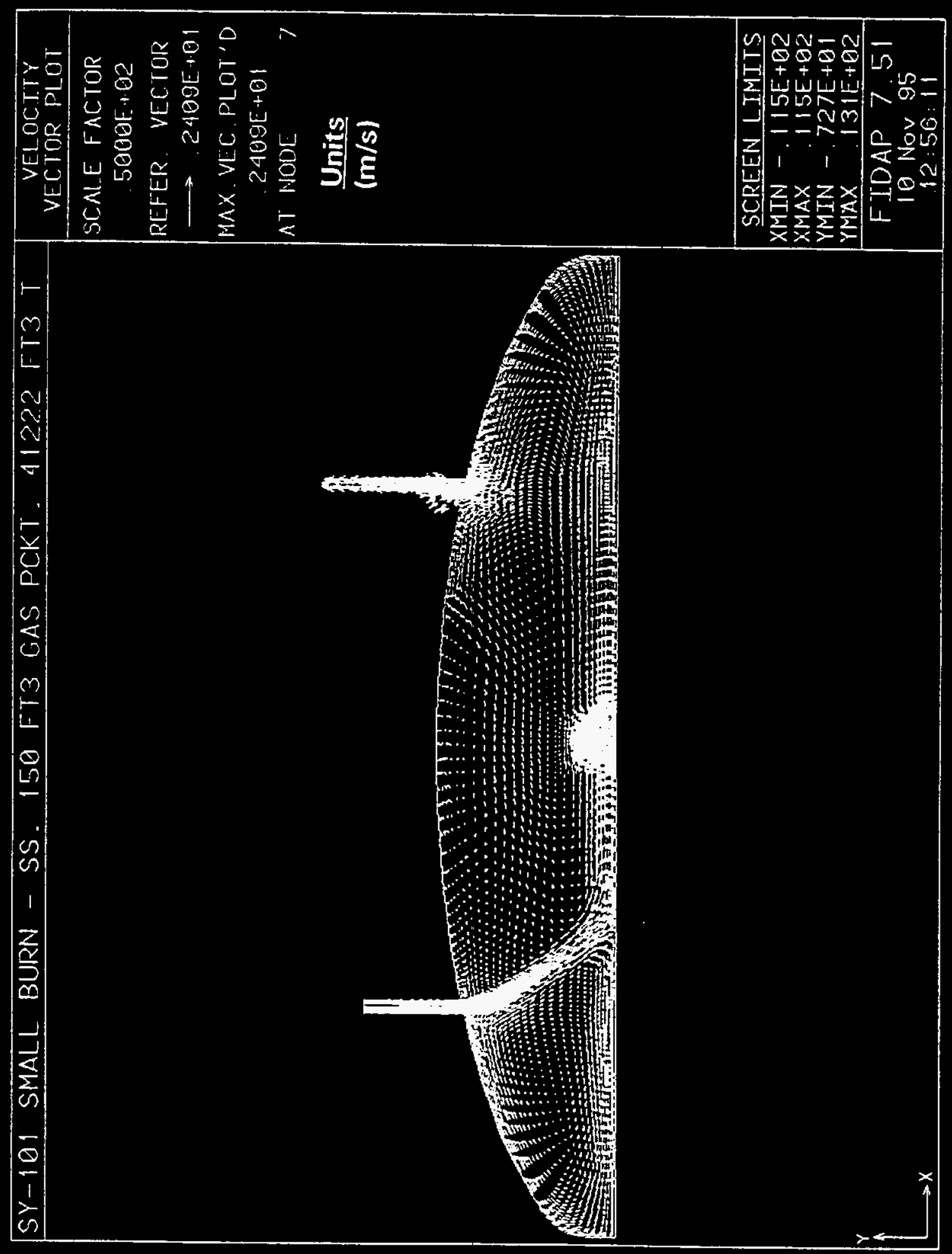


WHC-SD-WM-ER-515, Rev. 0

Figure 5-2. Steady-State Speed $(\mathrm{m} / \mathrm{s})$ Contours for Dome Airspace.

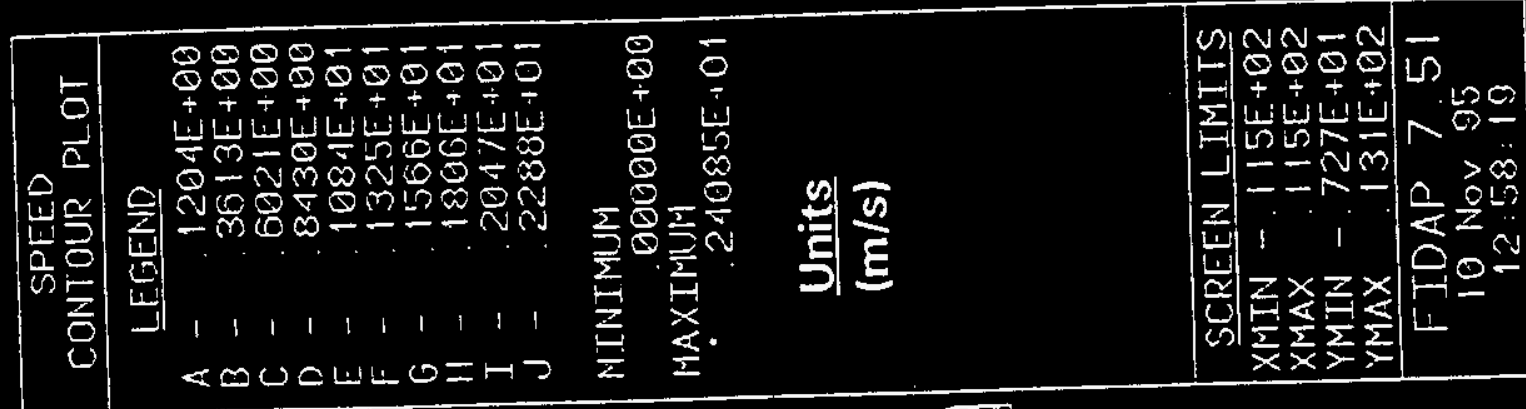

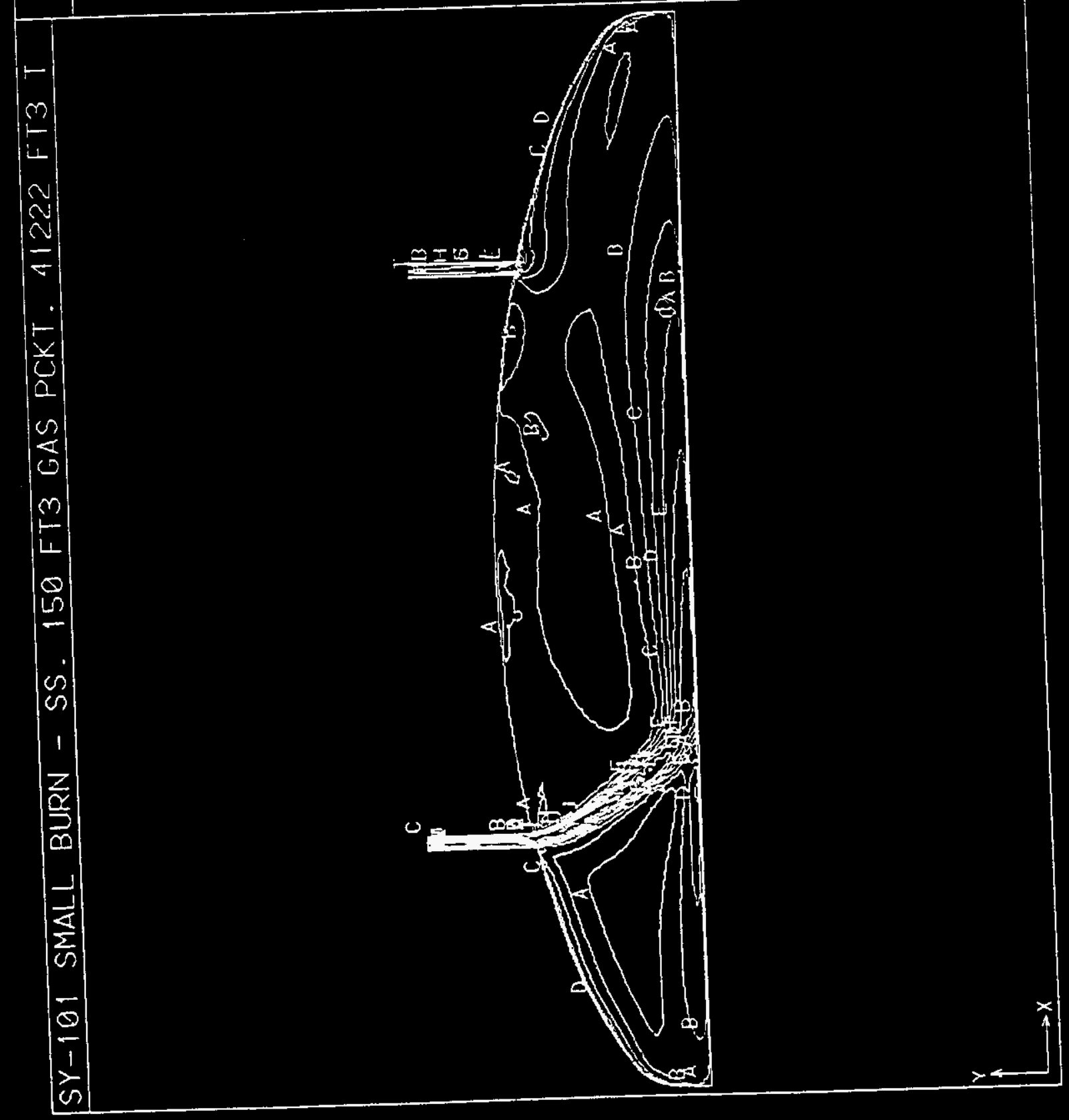


WHC-SD-WM-ER-515, Rev. 0

Figure 5-3. Steady-State Temperature $\left({ }^{\circ} \mathrm{K}\right)$ Contour for Dome Airspace.

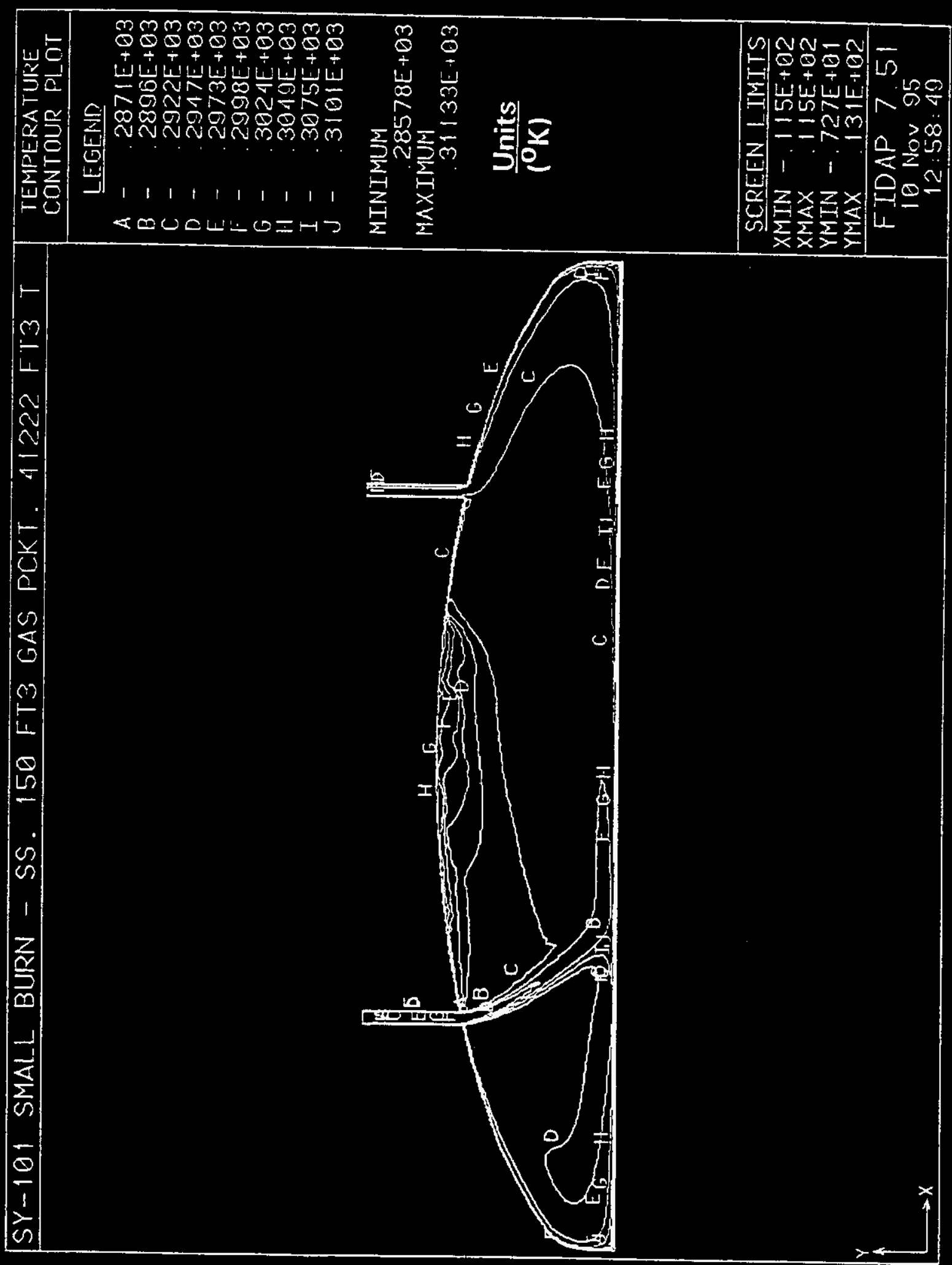


Figure 5-4. Maximum Dome Pressure vs Time for Nodes 18 or 40 for Various Volumes of Flammable Gas and Number of Reactions.
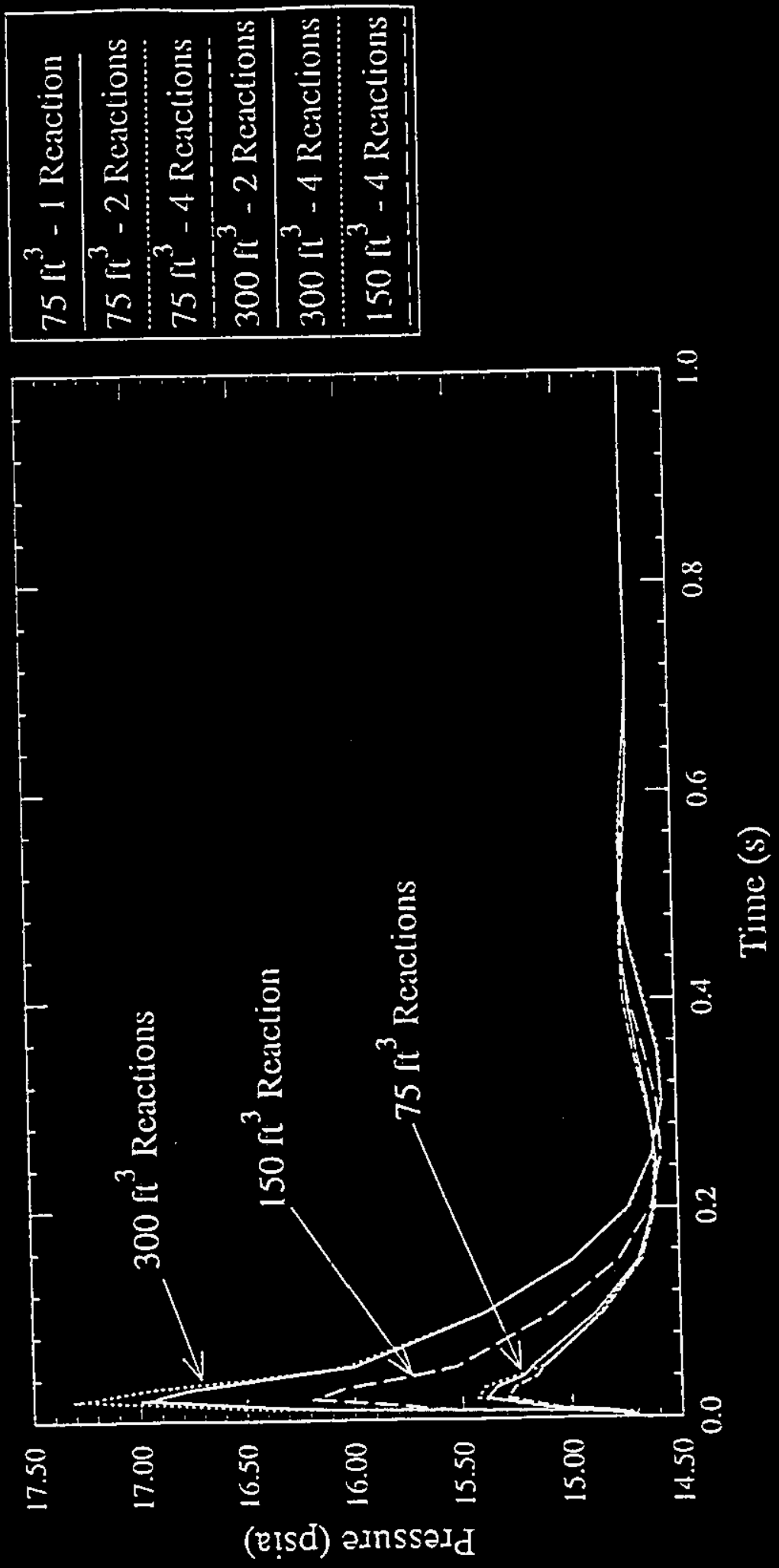
Figure 5-5. Naximum Differential Pressure vs Time for Nodes 18 or 40 for Various Volumes of Flammable Gas and Number of Reactions.
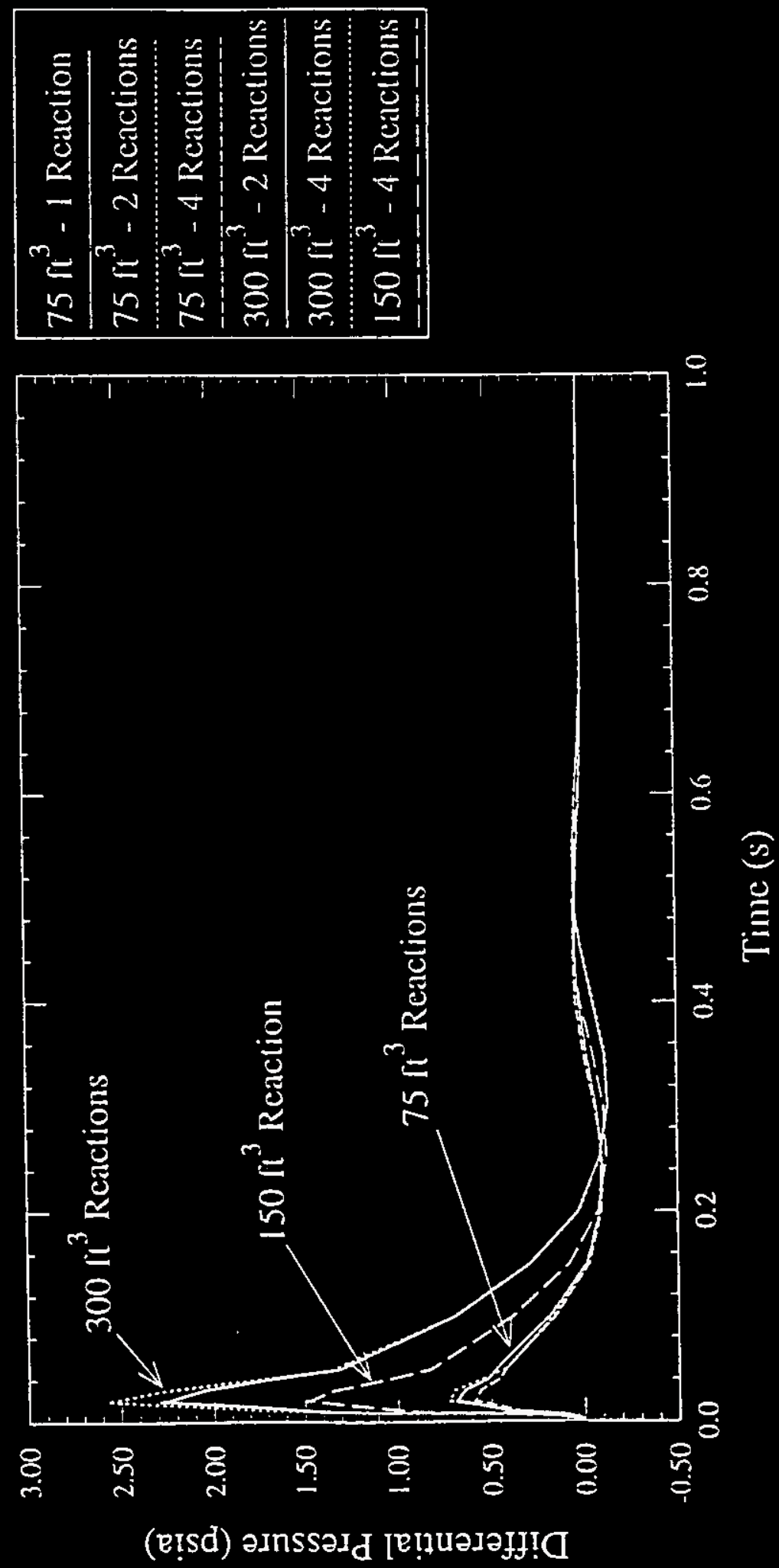
Figure 5-6. Transient Pressure $(t=0.0025 \mathrm{~s})$ for $150-\mathrm{ft}^{3}$ Flammable-Gas Plume Burn (4 Reactions).

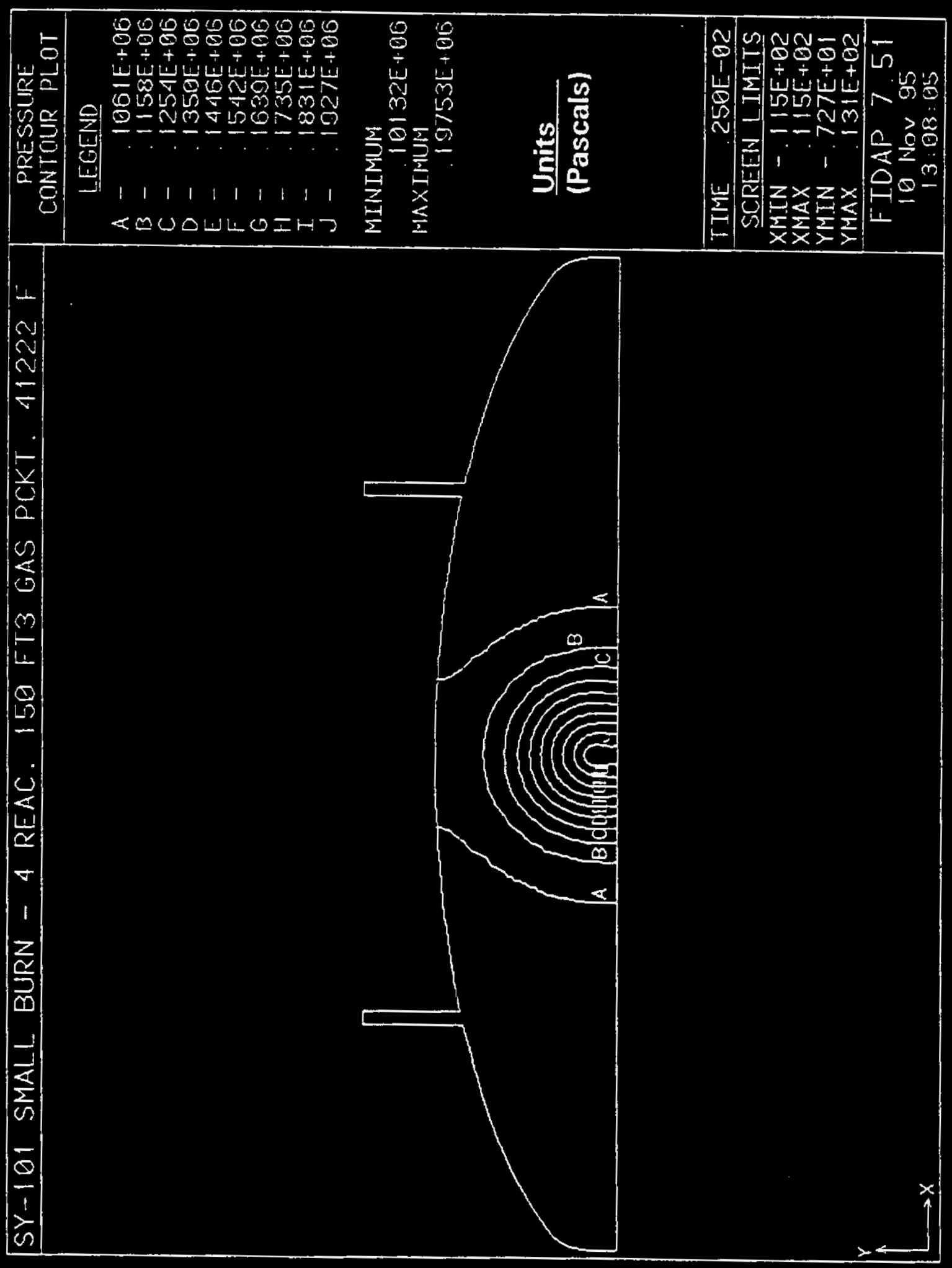


Figure 5-7. Transient Pressure $(t=0.0050 \mathrm{~s})$ for $150-\mathrm{ft}^{3}$ Flammable-Gas Plume Burn (4 Reactions).

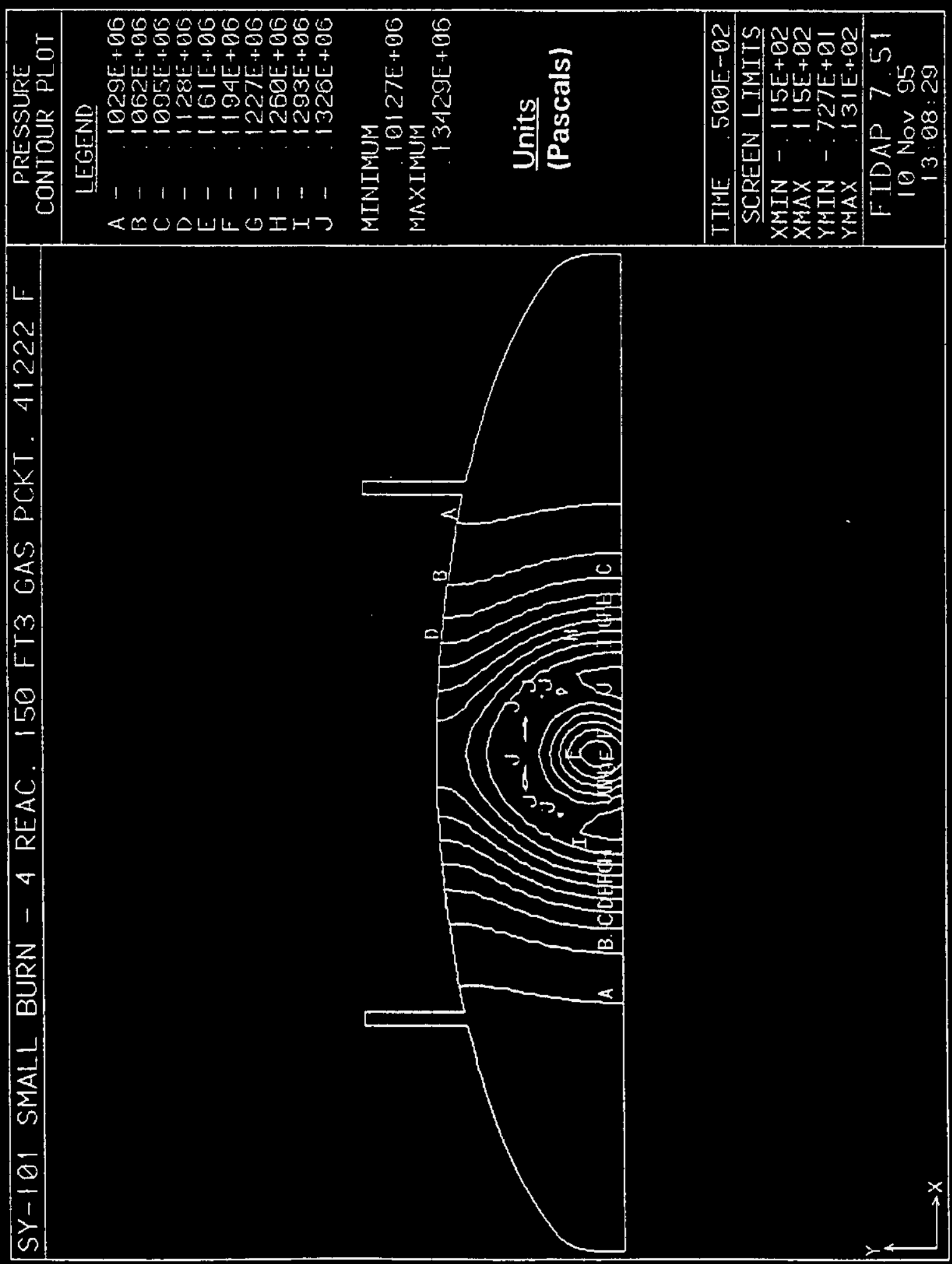


Figure 5-8. Transient Pressure $(t=0.0075 \mathrm{~s})$ for $150-\mathrm{ft}^{3}$ Flammable-Gas Plume Burn (4 Reactions).

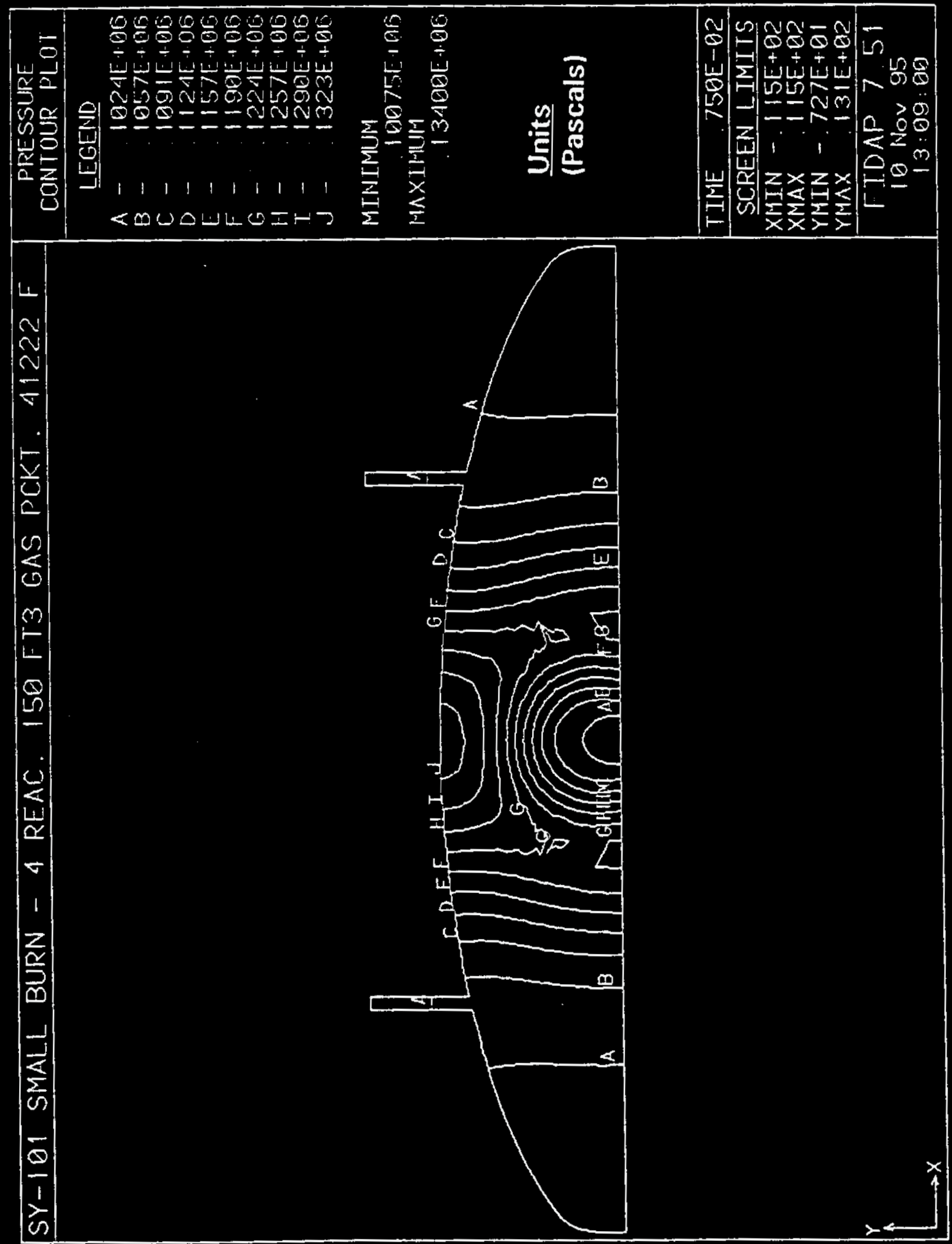


Figure 5-9. Transient Pressure $(t=0.0100 \mathrm{~s})$ for $150-\mathrm{ft}^{3}$ Flammable-Gas Plume Burn (4 Reactions).

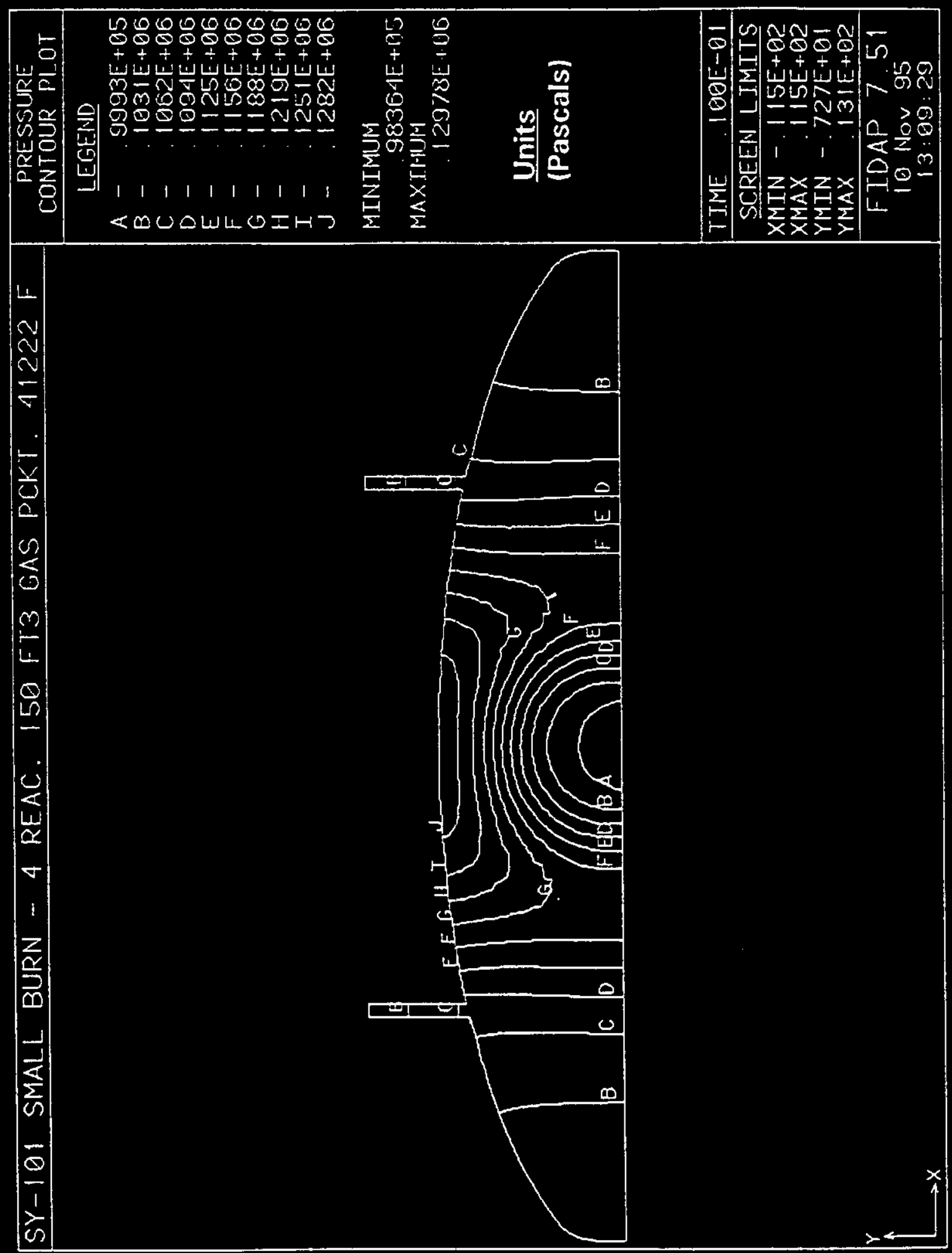


WHC-SD-WM-ER-515, Rev. 0

Figure 5-10. Transient Pressure $(t=0.0125 \mathrm{~s})$ for $150-\mathrm{ft}^{3}$ Flammable-Gas Plume Burn (4 Reactions).
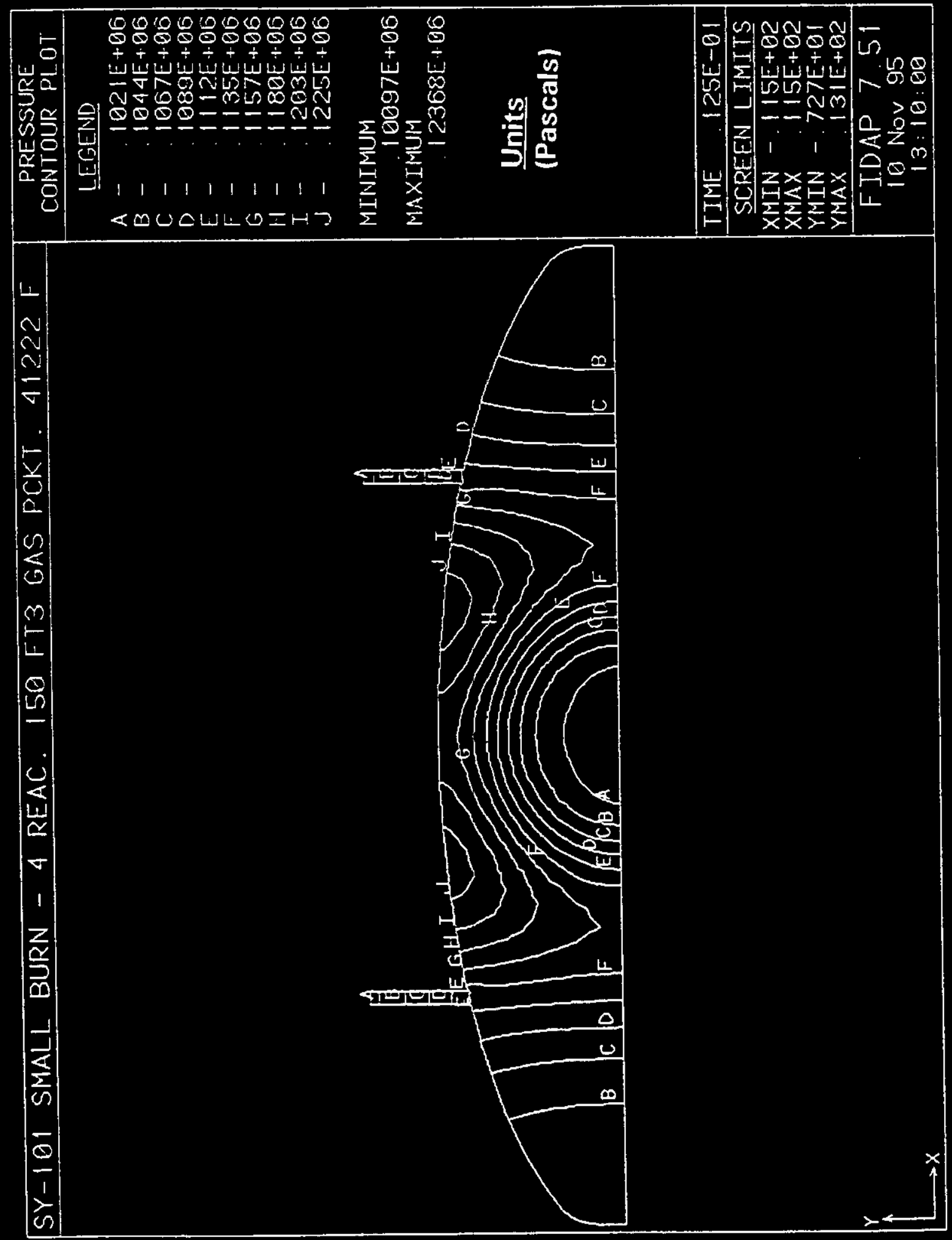
WHC-SD-WM-ER-515, Rev. 0

Figure 5-11. Transient Temperature $\left({ }^{\circ} \mathrm{K}\right)(t=0.05 \mathrm{~s})$ for $300-\mathrm{ft}^{3} \mathrm{Flammable-Gas}$ Plume Burn (4 Reactions).

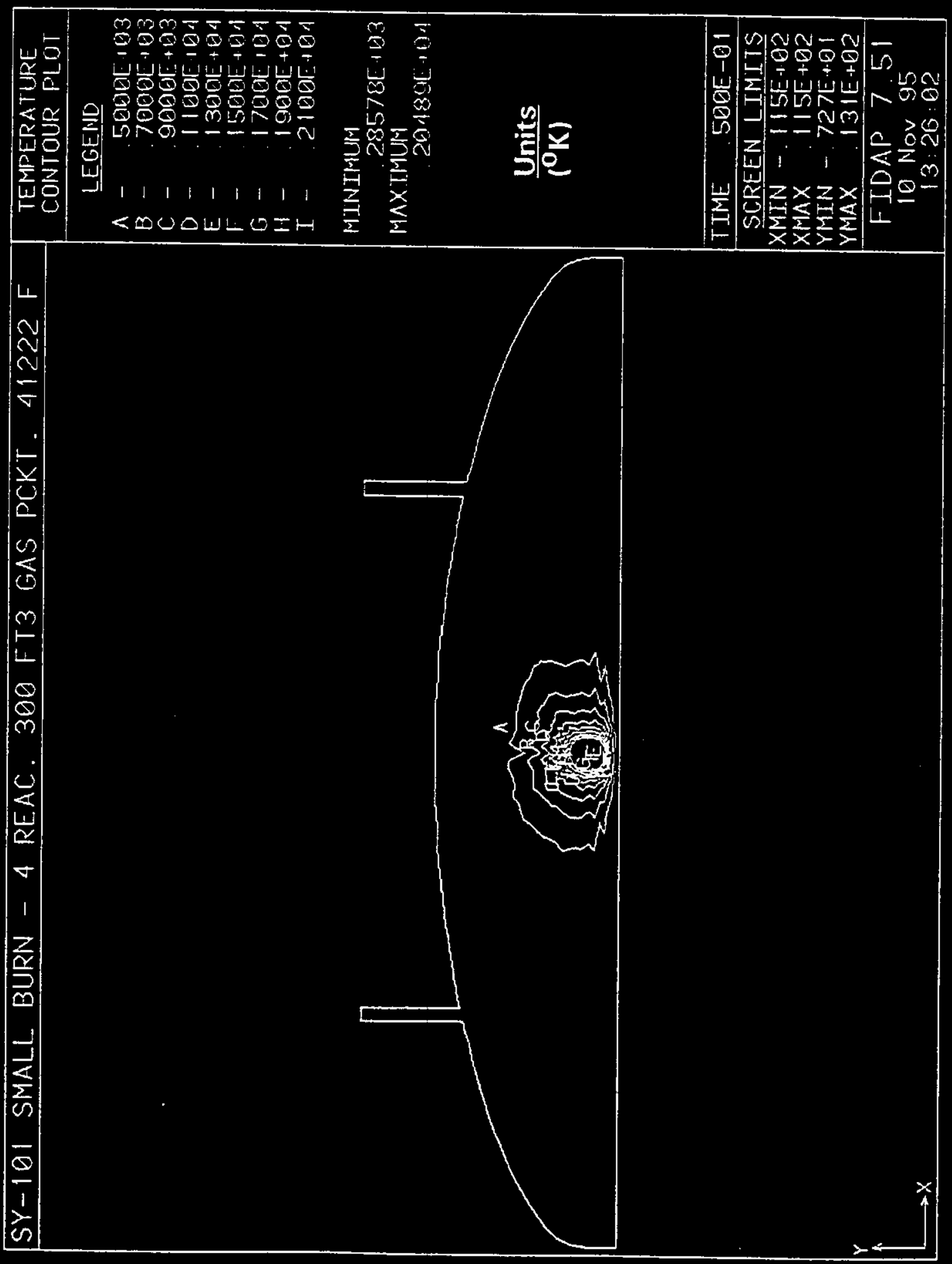


WHC-SD-WM-ER-515, Rev. 0

Figure 5-12. Transient Temperature $\left({ }^{\circ} \mathrm{K}\right)(t=0.50 \mathrm{~s})$ for $300-\mathrm{ft}^{3}$ Flanmable-Gas Plume Burn (4 Reactions).
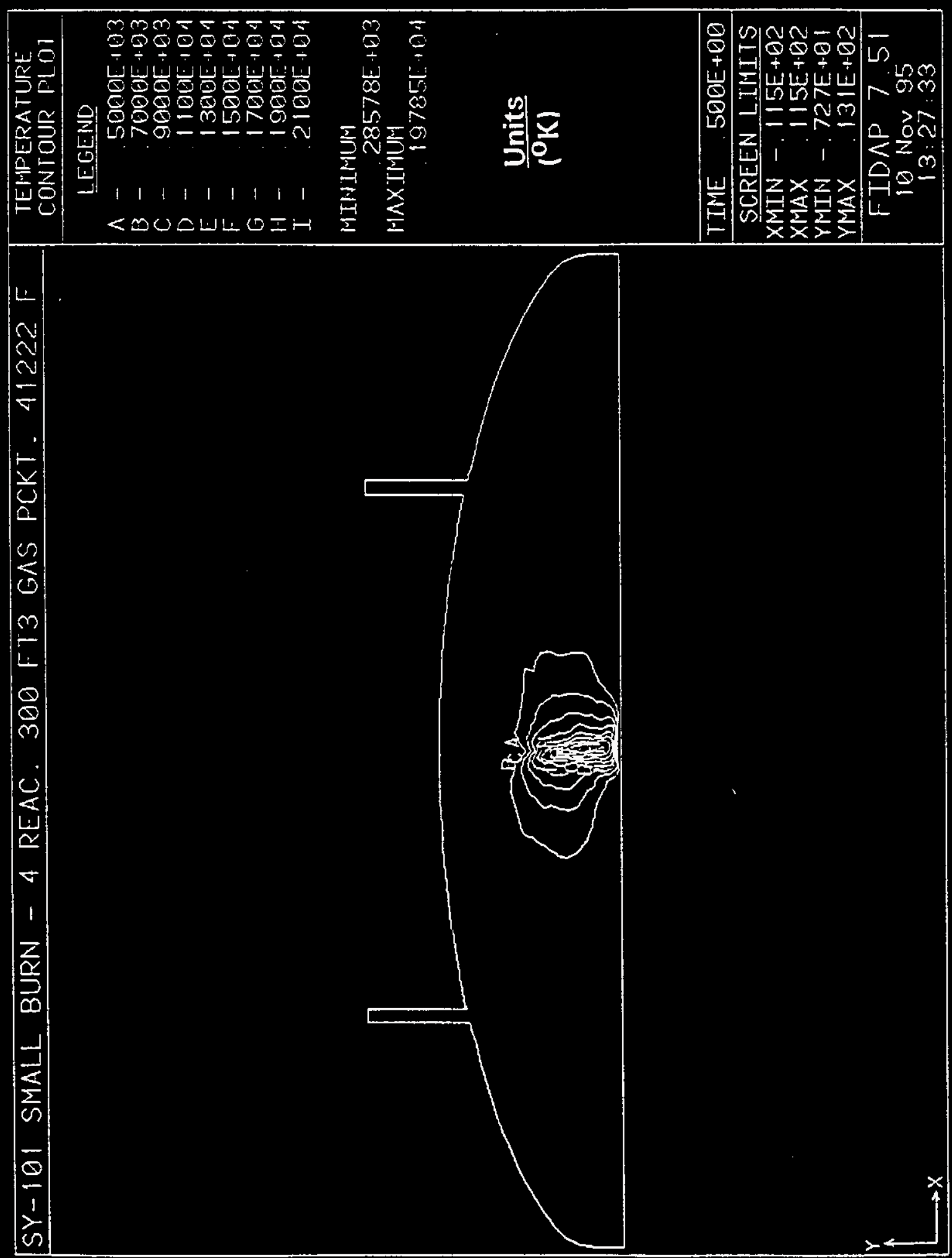
WHC-SD-WM-ER-515, Rev. 0

Figure 5-13. Transient Temperature $\left({ }^{\circ} \mathrm{K}\right)(\mathrm{t}=1.0 \mathrm{~s})$ for $300-\mathrm{ft}^{3} \mathrm{Fl}$ ammable-Gas Plume Burn (4 Reactions).

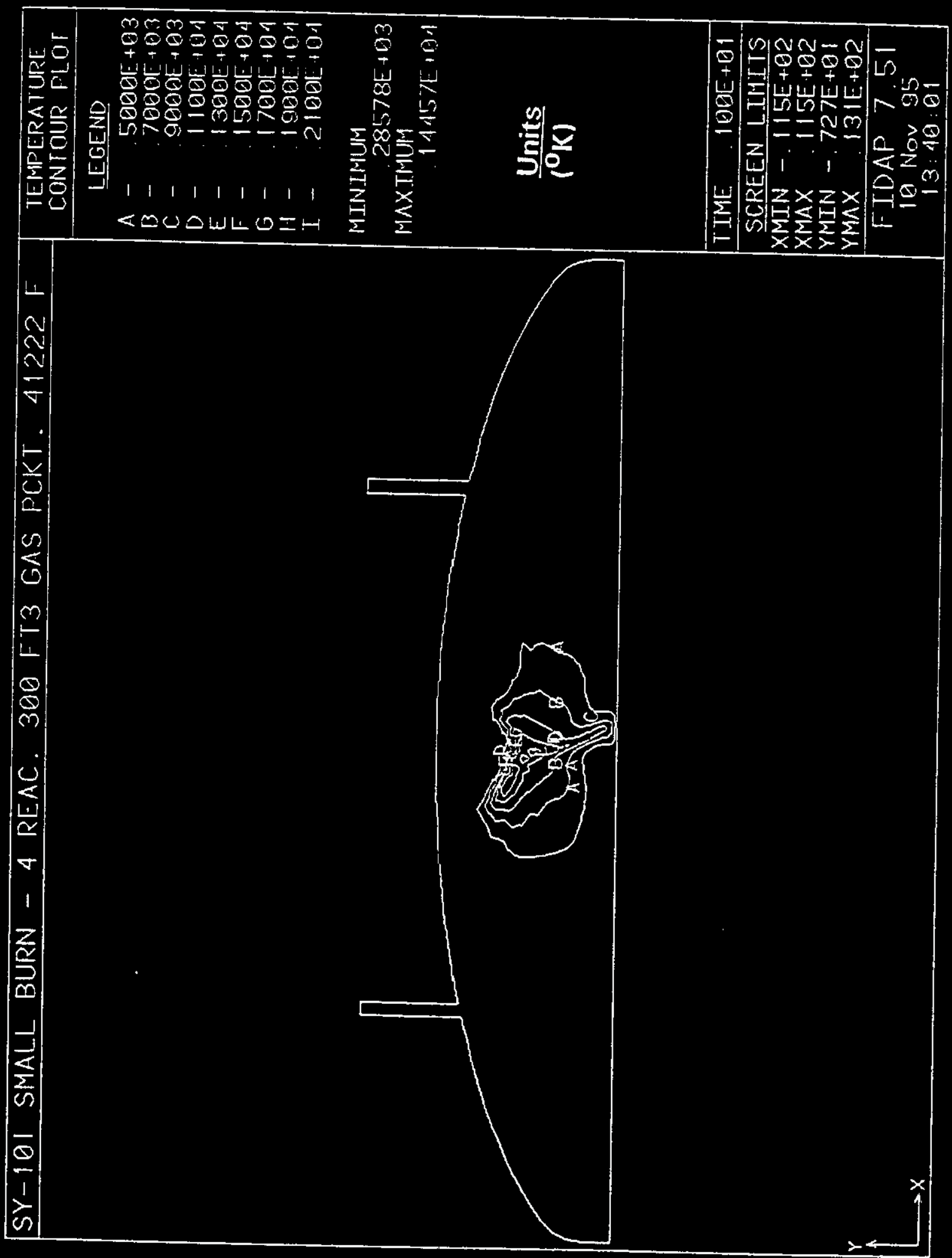


WHC-SD-WM-ER-515, Rev. 0

Figure 5-14. Transient Temperature $\left({ }^{\circ} \mathrm{K}\right)(\mathrm{t}=2.0 \mathrm{~s})$ for $300-\mathrm{ft}^{3}$ Flammable-Gas Plume Burn (4 Reactions).

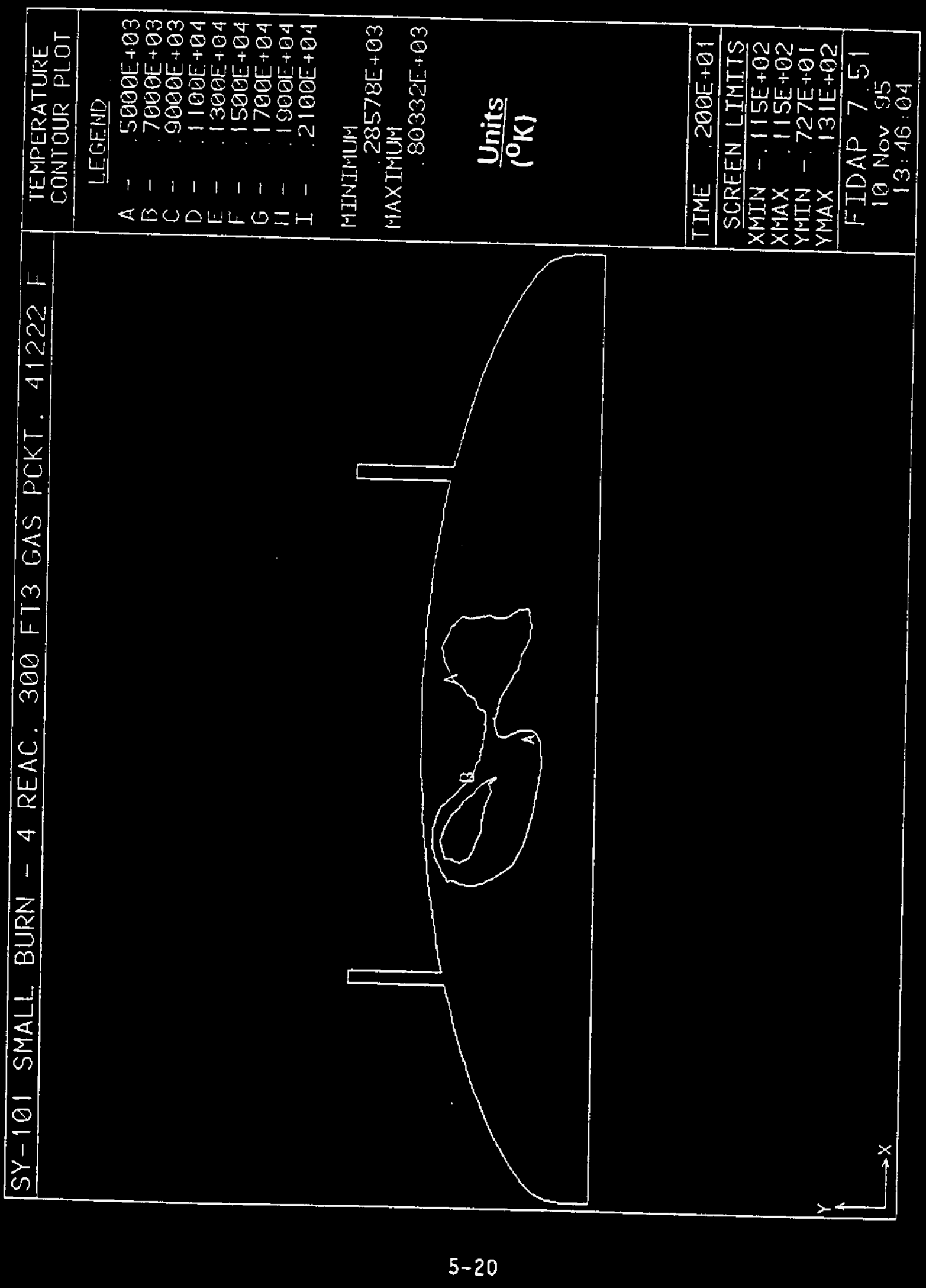


Figure 5-15. Transient Temperature $\left({ }^{\circ} \mathrm{K}\right)(t=3.0 \mathrm{~s})$ for $300-\mathrm{ft}^{3}$ Flammable-tas Plume Burn (4 Reactions).

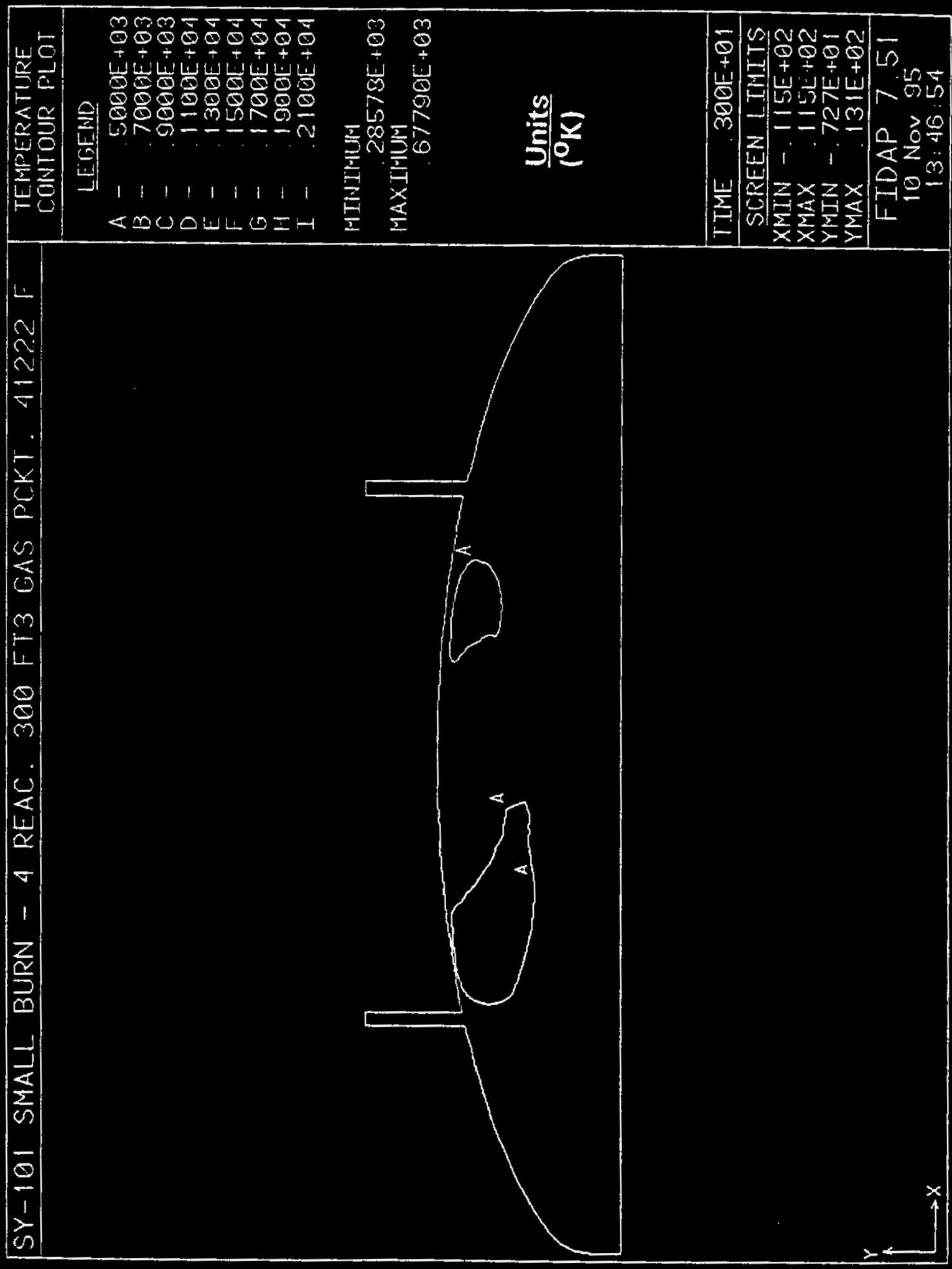


WHC-SD-WM-ER-515, Rev. 0

Figure 5-16. Transient Temperature $\left({ }^{\circ} \mathrm{K}\right)(\mathrm{t}=4.0 \mathrm{~s})$ for $300-\mathrm{ft}^{3}$ Flammable-Gas Plume Burn (4 Reactions).

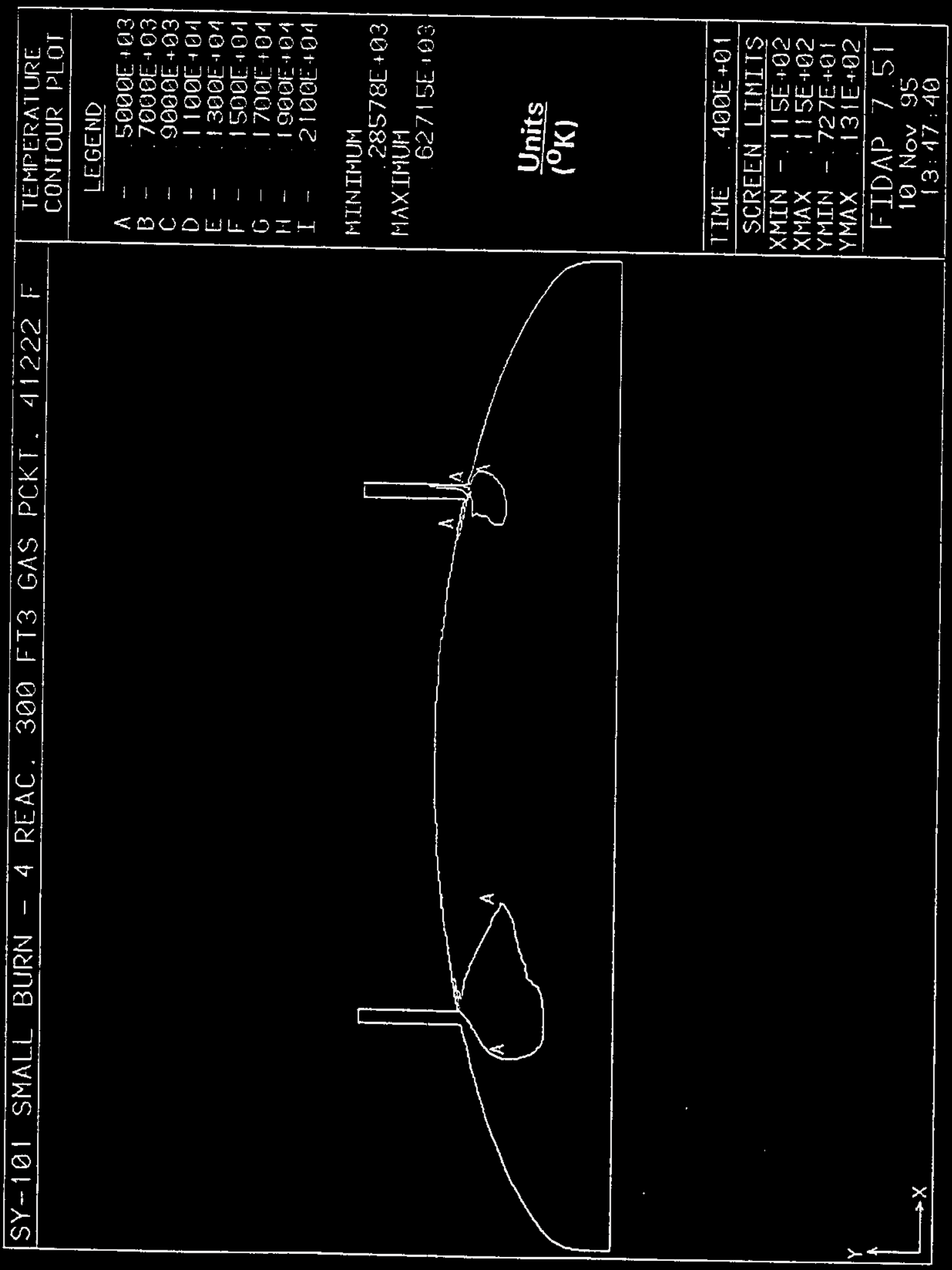


Figure 5-17. Transient Temperature $\left({ }^{\circ} \mathrm{K}\right)(\mathrm{t}=5.0 \mathrm{~s})$ for $300-\mathrm{ft}^{3}$ Flammable-Gas Plume Burn (4 Reactions).

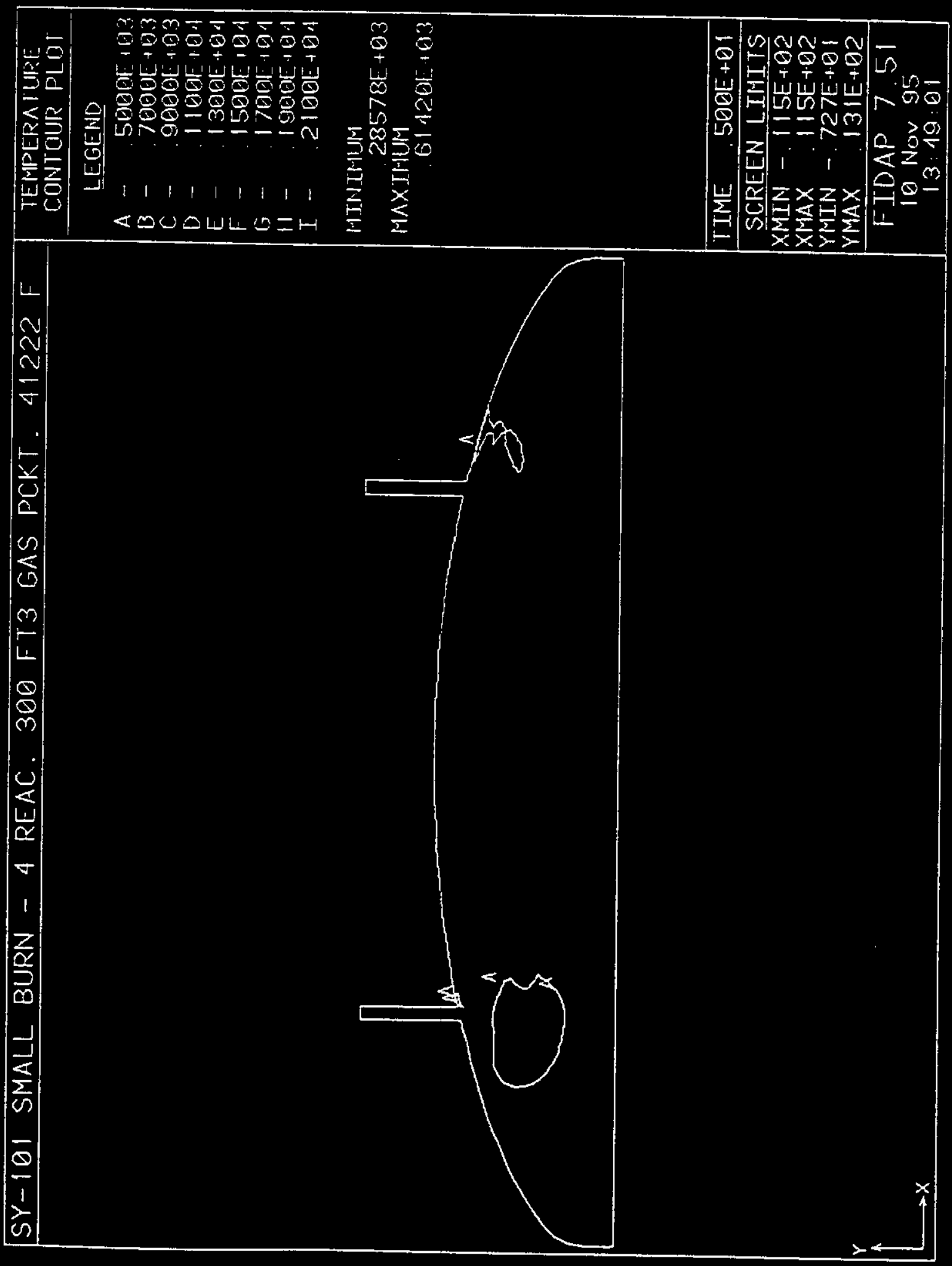


WHC-SD-WM-ER-515, Rev. 0

Figure 5-18. Transient Temperature $\left({ }^{\circ} \mathrm{K}\right)(\mathrm{t}=5.0 \mathrm{~s})$ with Reset Range for $300-\mathrm{ft}^{3}$ Flammable-Gas Plume Burn (4 Reactions).

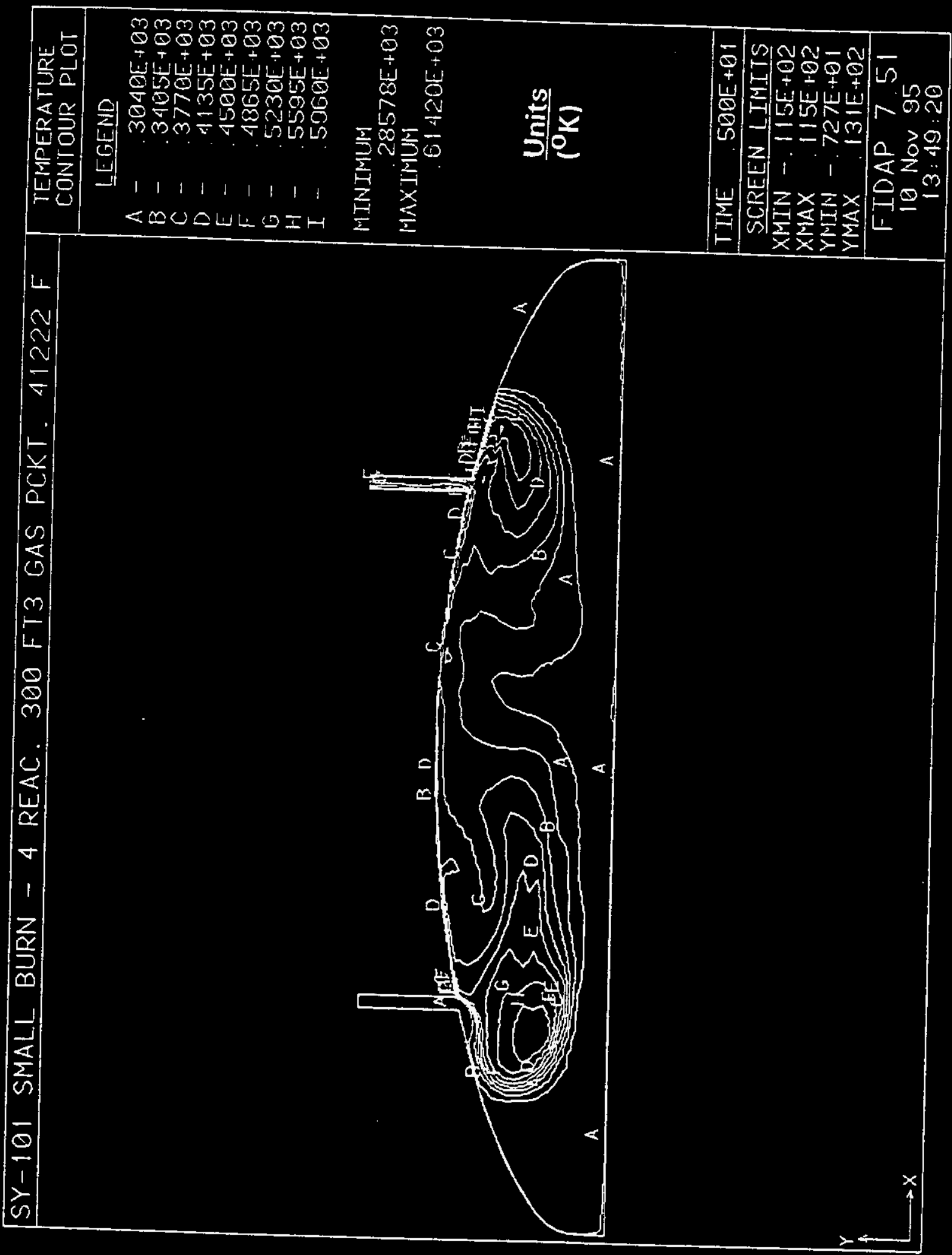


Figure 5-19. Transient Velocity $(\mathrm{m} / \mathrm{s})$ Vectors $(t=5.0)$ for $300-\mathrm{ft}^{3}$ Flammable-Gas Plume Burn (4 Reactions).

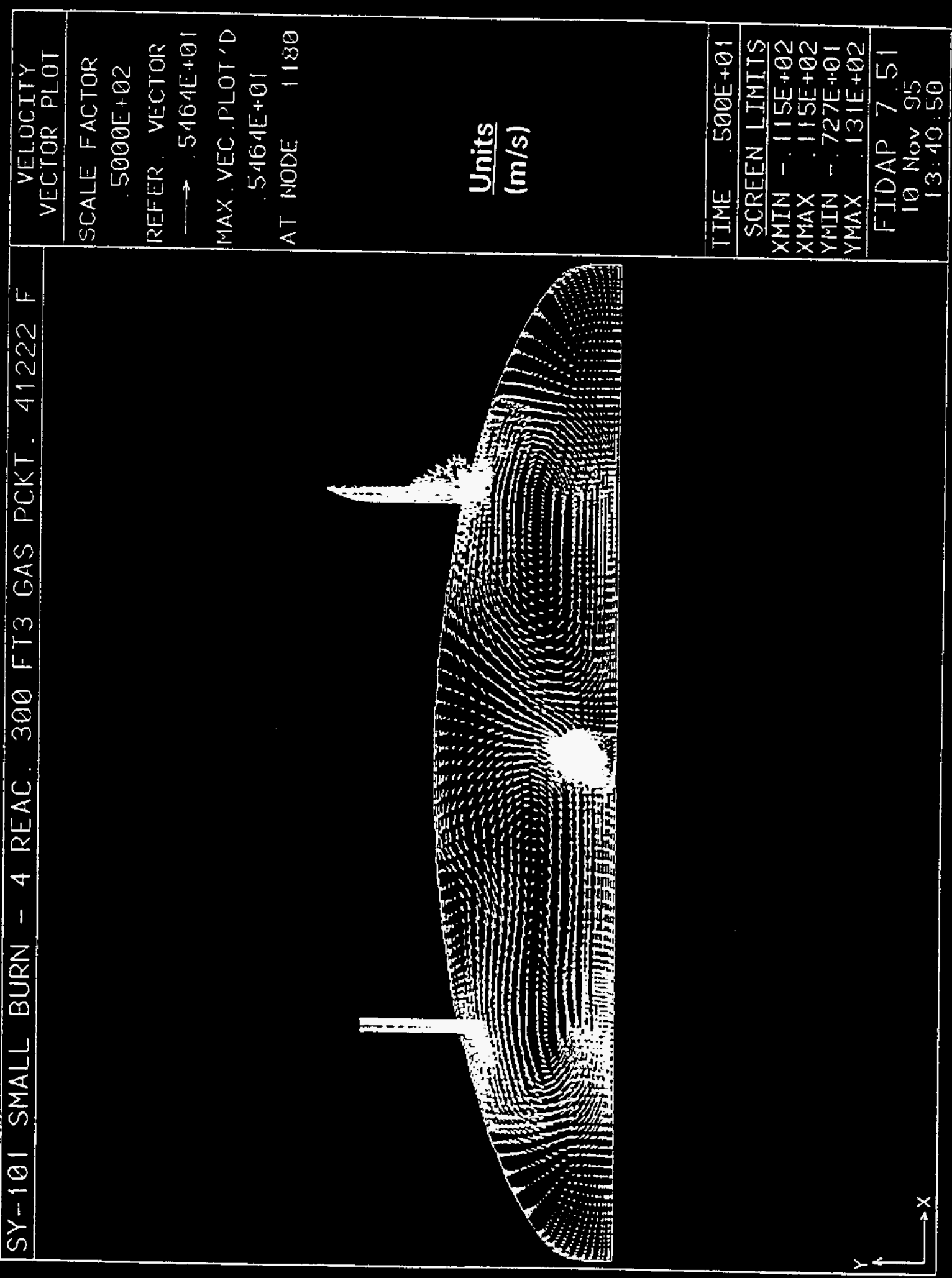


Figure 5-20. Transient Speed $(\mathrm{m} / \mathrm{s})$ Contour $(t=5.0)$ for $300-\mathrm{ft}^{3}$ Flammable-Gas Plume Burn (4 Reactions).

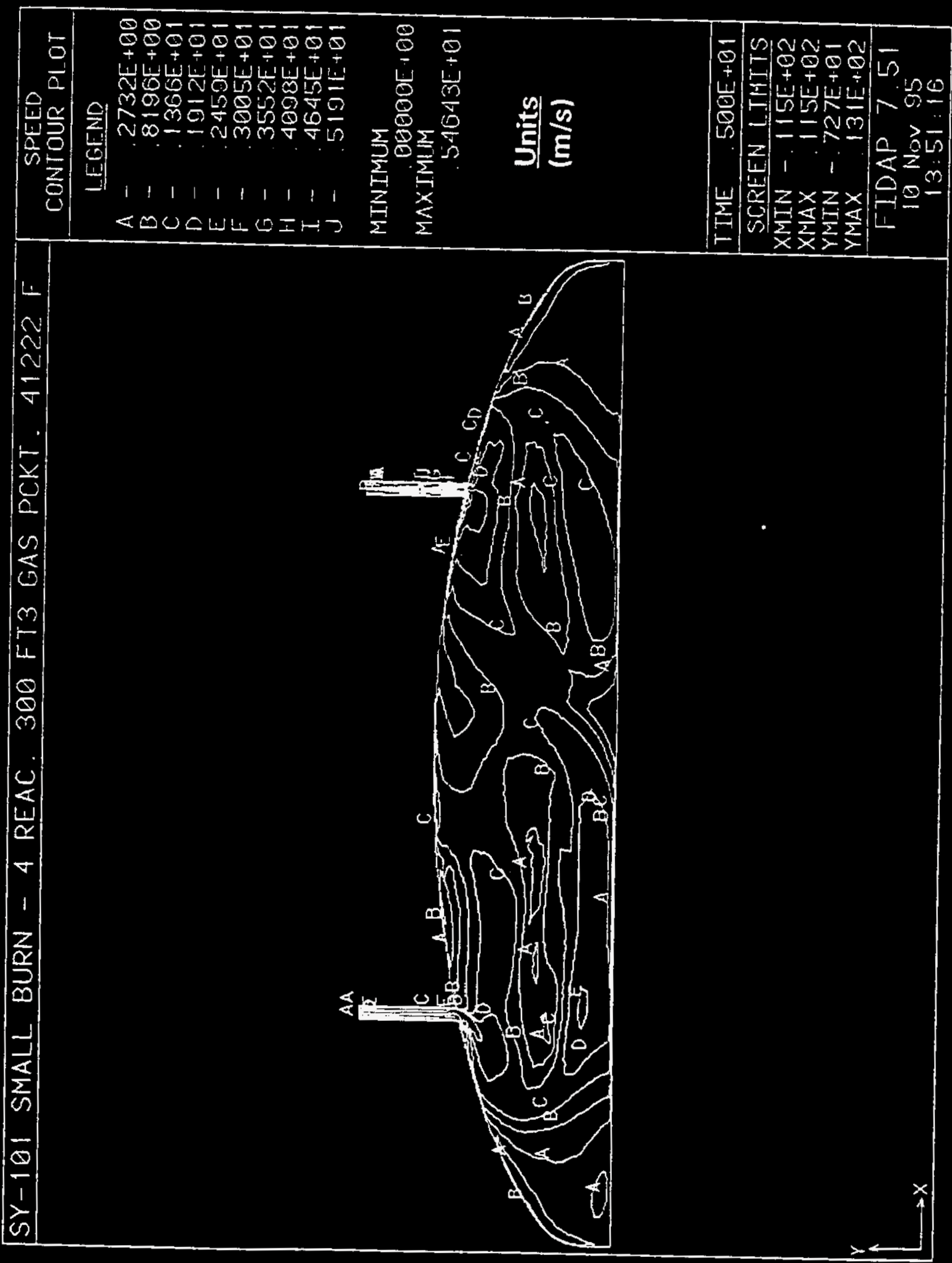


Figure 5-21. Yentilation System Transient Pressure vs Time for $75 \mathrm{ft}^{3}$ Flamable-Gas Plume Burn (1 Reaction).

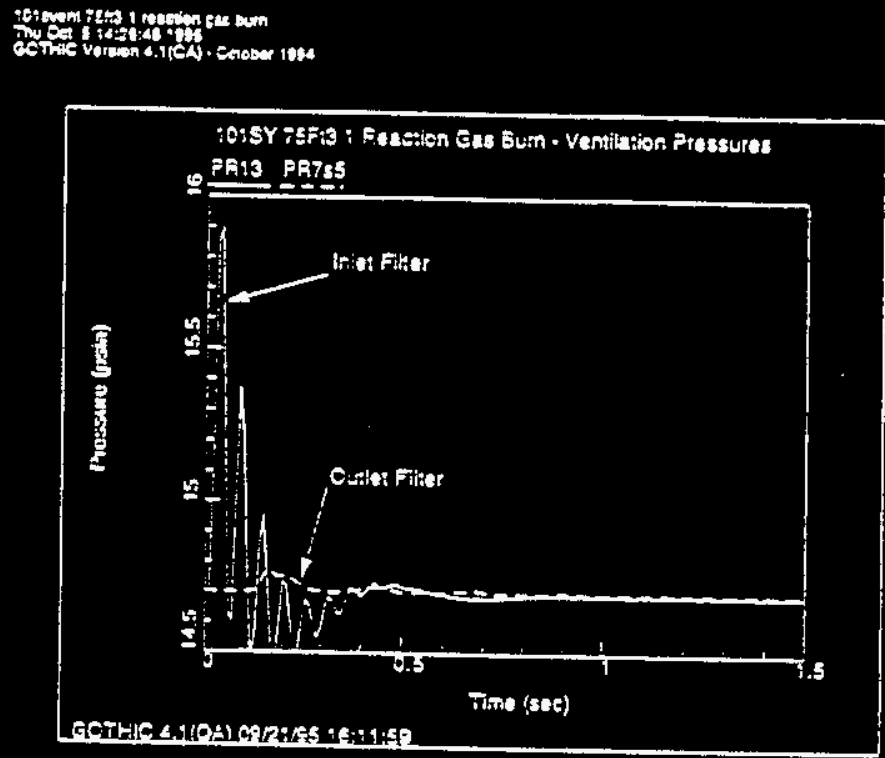

Figure 5-22. Ventilation System Transient Pressure vs Time for 75- $\mathrm{ft}^{3}$ Flamable-Gas Plume Burn (2 Reactions).

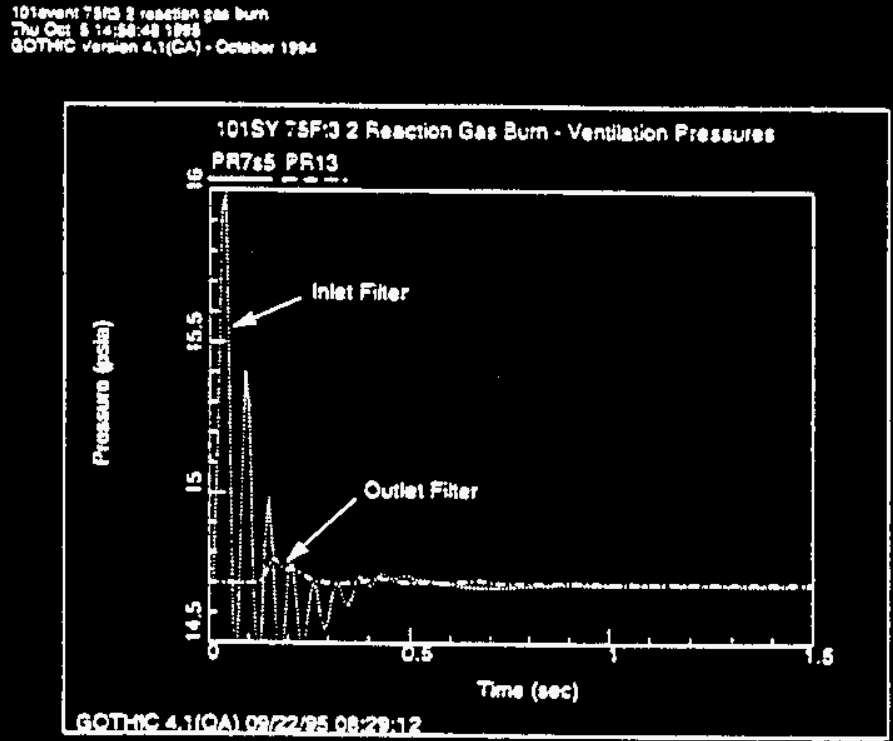


Figure 5-23. Ventilation System Transient Pressure vs Time for 75- $\mathrm{ft}^{3}$ Flanmable-Gas Plume Burn (4 Reactions).

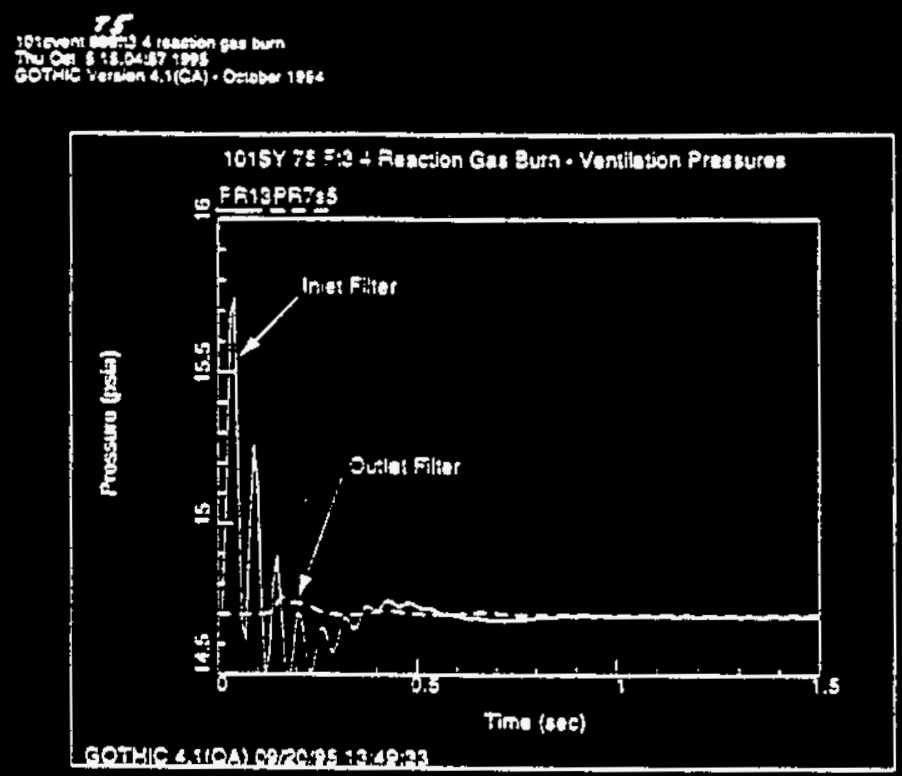

Figure 5-24. Yentilation System Transient Pressure vs Time for 150- $\mathrm{ft}^{3}$ Flamable-Gas Plume Burn (4 Reactions).

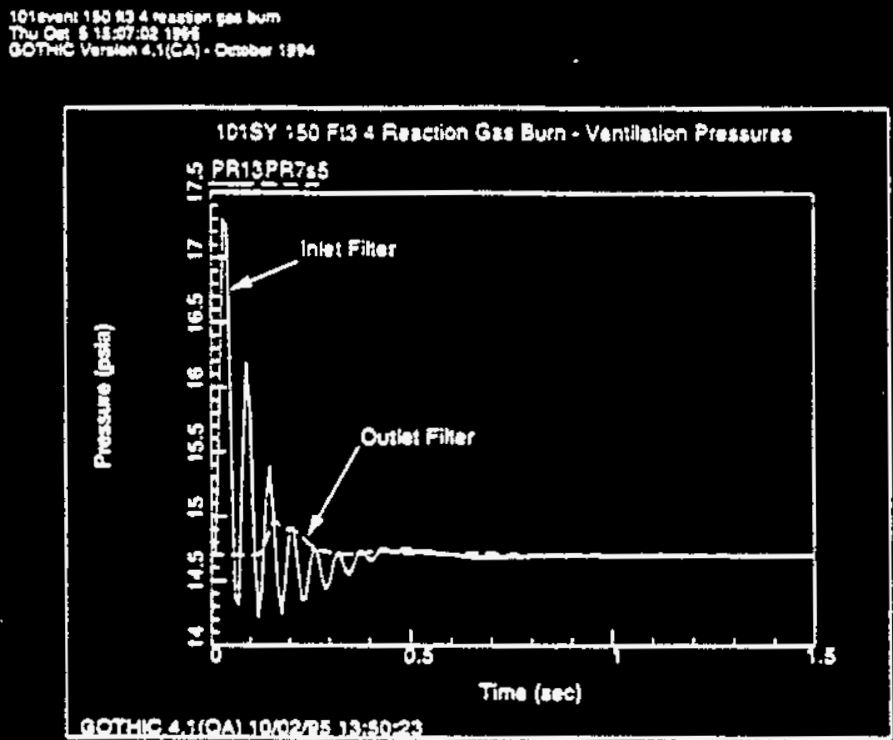


Figure 5-25. Kentilation System Transient Pressure vs Time for 300-ft ${ }^{3}$ Flamable-Gas Plume Burn (2 Reactions).

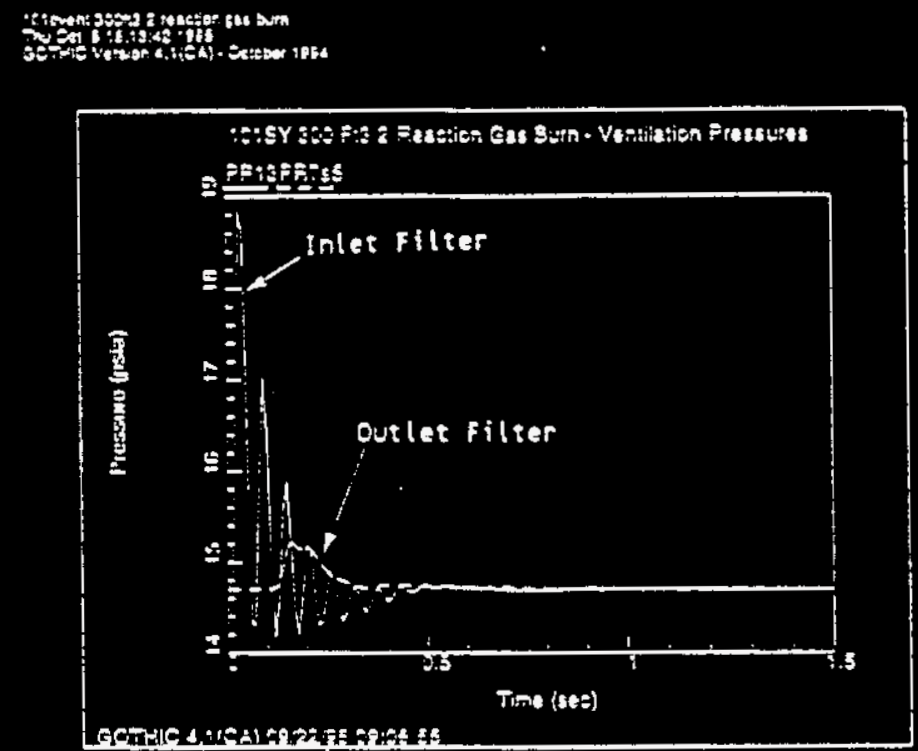

Figure 5-26. Ventilation System Transient Pressure vs Time for 300-ft Flammable-Gas Plume Burn (4 Reactions).

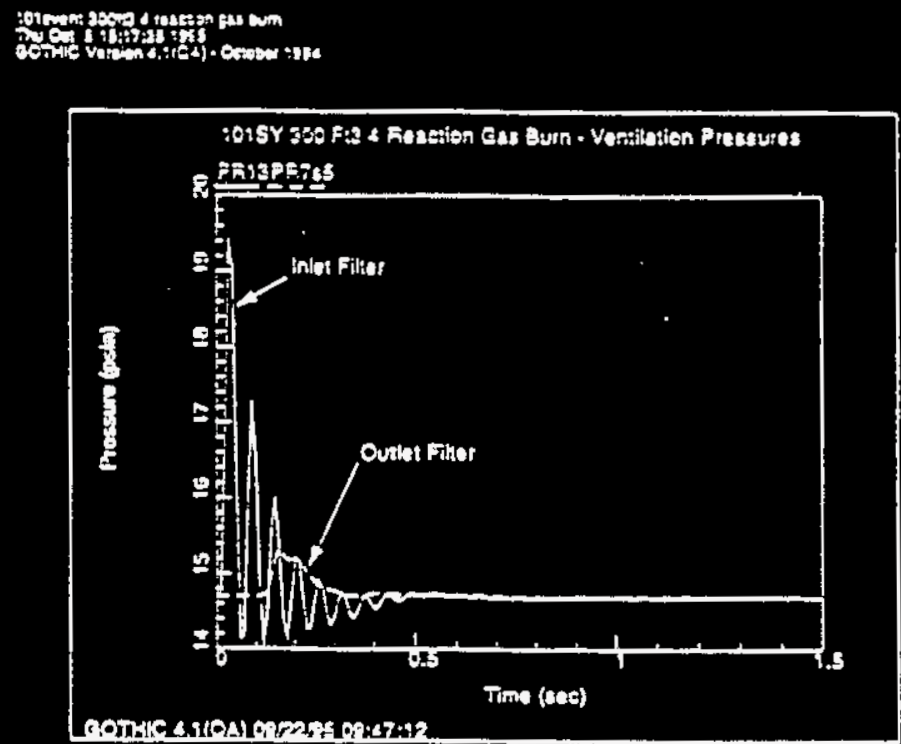




\subsection{CONCLUSIONS AND RECONHENDATIONS}

The results of the flammable-gas plume burn and ventilation-system response analyses are presented by Tables 5-2 and 5-4, and Figures 5-4, 5-5, and 5-21 through 5-26. The results indicate that the differential pressure 1 imit of 0.36 psia for the SY-101 tank inlet HEPA filter will be exceeded for a flammable-gas plume burn of $75 \mathrm{ft}^{3}$ or larger. Flammable-gas plume burns of less than $75 \mathrm{ft}^{3}$ were not investigated.

The results indicate that the differential pressure limit for the SY tank farm outlet HEPA filter will not be exceeded for flammable-gas plume burns of 75 and $150 \mathrm{ft}^{3}$. However, a flammable-gas plume burn of $300 \mathrm{ft}^{3}$ will exceed the differential pressure limit. A simple first order estimate using linear interpolation indicated the HEPA pressure difference failure threshold 0.36 psia $(2.49 \mathrm{KPa})$ is reached for a flammable-gas plume burn of approximately $190 \mathrm{ft}^{3}$. This remains to be confirmed. It must be emphasized that the results presented in Table 5-4 and Figures 5-21 through 5-26 reflect the dynamic response of the ventilation system based on constant loss coefficients. The response of the SY tank farm ventilation system is assumed to be representative up to the point of exceeding the maximum differential pressure limit of the HEPA filters. Filter failure, with a corresponding change in the loss coefficient, was not modeled.

The number of simulated chemical reactions appears to have a minor effect on the results as shown by Tables 5-2 and 5-4. However, the volume of flammable gas has a much more pronounced affect, as one would expect given that more reaction mass and, hence, energy is available.

The SY tank farm ventilation system will mitigate any propagating pressure wave to some extent. The pressure wave is split several times as a result of the " $T$ " junctions within the SY tank farm ventilation system. The SY-102 and SY-103 waste tanks act as large accumulators dissipating the pressure wave. Additional pressure losses occur from wall friction and geometrical form changes. The results presented in this report reflect the response of only tank SY-101 and the SY tank farm ventilation system to a flammable-gas plume burn. Other tanks with different dome airspace volumes, gas concentrations, gas compositions, ventilation configurations, etc., even a burn within different tanks within the same system, will respond differently to a flammable-gas plume burn.

It is possible that tank farms with much more extensive ventilation systems, such as the SX tank farm, may be able to dissipate a pressure wave resulting from a much larger flammable-gas plume burn and not fail the outlet HEPA filter. This is especially true for those systems that may use flows through a series of connected tanks or combined flow through one tank just before the exhaust HEPA filter. However, it is doubtful that the inlet filters associated with any of the hydrogen watch list tanks will remain intact for even a small burn of $75 \mathrm{ft}^{3}$. 
WHC-SD-WM-ER-515, Rev. 0

This is especially true for most single-shell tanks where the ventilation system usually consists of one or two HEPA filters on small-diameter (4 in.) risers and relies on natural breathing due to barometric pressure changes. (The notable exception to this is the single-shell SX tank farm, which has an active ventilation system.)

It is recommended that the remaining hydrogen watch list tanks and ventilation systems, as shown in Table $1-1$, be analyzed to determine the response to a small flammable-gas plume burn. 


\subsection{REFERENCES}

Burke, T. M., 1990, FATHOMS Analys is of Double-shell Tank SY-101 Gas Release, WHC-SD-WM-ER-067, Rev. 0, Westinghouse Hanford Company, Richland, Washington.

Burke, T. B., 1990, FATHOMS Computer Code Software QA Package, WHC-SD-FF-ER-054, Rev. 0, Westinghouse Hanford Company, Richland, Washington.

Dosanjh, S., 1995, Recursive Speedup, Computational Science and Engineering, Spring 1995, pages 4-5.

Drawing H-2-71975, Rev, 2, Tank Cross Section 241-AN Tanks, Westinghouse Hanford Company, Richland, Washington.

Hopkins, J. D., 1994, Criteria for Flammable Gas Watch List Tanks, WHC-EP-0702, Rev. 0, Westinghouse Hanford Company, Richland, Washington.

Heard, F. J., 1994, FIDAP Version 7.06 - Validation/Verification, WHC-SD-WM-ER-302, Rev. 1, Westinghouse Hanford Company, Richland, Washington.

Jo, J., 1992, Laboratory Flammability Studies of Mixtures of Hydrogen, Nitrous Oxide, and Air, WHC-SD-WM-ES-219, Rev. 0, Westinghouse Hanford Company, Richland, Washington.

Journal of Physical and Chemical Reference Data, JANAF Thermochemical Tables, Third Edition, Volume 14, Supplement 1, 1985.

LANL, 1994, A Safety Assessment for Proposed Pump Mixing Operations to Mitigate Episodic Gas Releases in Tank 241-SY-101, Los Alamios National Laboratory, Los Alamos, New Mexico.

Powers, T. A., 1993, Letter Report on Determining Probabilistic Criteria for Flammable Gas Watch List Tanks (internal letter 29220-93-TBP-043 to G. D. Johnson, December 3, 1993), West inghouse Hanford Company, Richland, Washington.

WHC, 1995, Operating Specification for the 241-AN, -AP, -AN, $-A Y$, -AZ, and SX Tank Farms, OSD-T-151-00007, Westinghouse Hanford Company, Richland, Washington.

Wood, S. A., 1994, GOTHIC Installation Validation for Version 3.5, WHC-SD-WM-ER-299, Rev. O, Westinghouse Hanford Company, Richland, Washington. 
WHC-SD-WM-ER-515, Rev. 0

APPENDIX A. YALIDATION OF CHENICAL REACTION CAPABILITIES OF FIDAP. 


\section{INTRODUCTION}

A series of validation analyses was performed to verify the chemicalreaction capabilities of FIDAP. These analyses consisted of a series of simple test cases using one-step and multiple competing reaction models. The results from these analyses were compared to theoretical results for finalstate mass fractions and adiabatic temperatures. Additional analyses were performed simulating laboratory flammability studies performed by the Bureau of Mines (BOM) (Jo 1992).

\section{TEST CASES}

FIDAP's chemical reaction capabilities were exercised and compared against theoretical results for final-state mass fractions and adiabatic temperatures.

Two test cases were performed. The first case simulated a single reaction as follows.

$$
\mathrm{N}_{2} \mathrm{O}+\mathrm{H}_{2} \rightarrow \mathrm{H}_{2} \mathrm{O}+\mathrm{N}_{2}
$$

The second test case simulated two competing reactions as follows.

$$
\begin{aligned}
& \mathrm{N}_{2} \mathrm{O}+\mathrm{H}_{2} \rightarrow \mathrm{H}_{2} \mathrm{O}+\mathrm{N}_{2} \\
& 3 \mathrm{~N}_{2} \mathrm{O}+2 \mathrm{NH}_{3} \rightarrow 3 \mathrm{H}_{2} \mathrm{O}+4 \mathrm{~N}_{2}
\end{aligned}
$$

The initial mass fractions are shown in Appendix D, Table D-I, where the single reaction above represented the 50 percent mixture. The two reaction test cases are representative of the WHC conservative.

Table A-1 presents the final mass fractions and adiabatic temperatures as predicted by hand calculations. Comparisons are made with the finite-state conditions predicted by FIDAP. The results show excellent agreement.

\section{BUREAU OF NINES}

A series of validation analyses were also performed using an axisymmetric representation of the Bureau of Mines (BOM) test chamber as shown in Figures $A-1$ and $A-2$.

FIDAP was used to simulate a recent BOM flammability study of a mixture of 10 percent nitrous oxide and 10 percent hydrogen in air. Table A-2 and Figure A-3 present the results of the analysis.

Table A-2 compares the final-state mass fractions as predicted by a simple hand calculation and FIDAP, assuming a premixed mixture and complete combustion. Peak pressures were also compared. 
Figure A-3 compares the transient pressures as predicted by FIDAP and measured during the BOM test. The FIDAP results are based on the reaction parameters documented in Appendix $C$ and assumed a hot-spot temperature of $500^{\circ} \mathrm{K}$ to accelerate the reaction. The BOM results used a smal1 explosive device to start the reaction.

Table A-1. Comparison of Hand Calculations and FIDAP Results.

\begin{tabular}{|c|c|c|c|c|}
\hline & \multicolumn{2}{|c|}{$\mathrm{N}_{2} \mathrm{O}+\mathrm{H}_{2} \rightarrow \mathrm{H}_{2} \mathrm{O}+\mathrm{N}_{2}$} & \multicolumn{2}{|c|}{$\begin{aligned} \mathrm{N}_{2} \mathrm{O}+\mathrm{H}_{2} & \rightarrow \mathrm{H}_{2} \mathrm{O}+\mathrm{N}_{2} \\
3 \mathrm{~N}_{2} \mathrm{O}+2 \mathrm{NH}_{3} & \rightarrow 3 \mathrm{H}_{2} \mathrm{O}+4 \mathrm{~N}_{2}\end{aligned}$} \\
\hline & \multicolumn{2}{|c|}{ Final Mass Fractions } & \multicolumn{2}{|c|}{ Final Mass Fractions } \\
\hline Species & Predicted & FIDAP & Predicted & FIDAP \\
\hline $\mathrm{N}_{2} \mathrm{O}$ & 0.0 & 0.0003 & 0.0 & 0.0 \\
\hline $\mathrm{H}_{2}$ & 0.0 & 0.0000 & 0.0021 & 0.0021 \\
\hline $\mathrm{H}_{2} \mathrm{O}$ & 0.4106 & 0.4104 & 0.3975 & 0.3975 \\
\hline $\mathrm{N}_{2}$ & 0.5894 & 0.5893 & 0.6004 & 0.6004 \\
\hline $\mathrm{NH}_{3}$ & -- & -- & 0.0 & 0.0 \\
\hline \multirow[t]{4}{*}{ Total mass fraction } & 1.0000 & 1.0000 & 1.0000 & 1.000 \\
\hline & \multicolumn{2}{|c|}{$\begin{array}{c}\text { Adiabatic Temperature } \\
\left({ }^{\circ} \mathrm{F}\right)\end{array}$} & \multicolumn{2}{|c|}{$\begin{array}{r}\text { Adiabatic Temperature } \\
\left({ }^{\circ} \mathrm{F}\right)\end{array}$} \\
\hline & Predicted & FIDAP & Predicted & FIDAP \\
\hline & 5354.6 & 5360 & 4757.5 & 4757.8 \\
\hline
\end{tabular}

The results are in close agreement considering the time scale. However, the FIDAP results show a much faster rate of pressure rise. The BOM data shows a drop off in peak consistent with the condensation of water vapor and heat transfer through the walls of the test chamber. The corresponding FIDAP model is assumed to be adiabatic and water vapor is assumed not to condense. 
WHC-SD-WM-ER-515, Rev. 0

Table A-2. Comparison of FIDAP and Bureau of Mine Results for a Mixture of 10 Percent Hydrogen and 10 Percent Nitrous Oxide in Air.

\begin{tabular}{|c|c|c|}
\hline & \multicolumn{2}{|c|}{ Final Mass Fraction } \\
\hline & Predicted & FIDAP \\
\hline $\mathrm{N}_{2} \mathrm{O}$ & 0.0 & 0.00008 \\
\hline $\mathrm{H}_{2}$ & 0.0 & 0.00000 \\
\hline $\mathrm{H}_{2} \mathrm{O}$ & 0.06497 & 0.06494 \\
\hline $\mathrm{N}_{2}$ & 0.73174 & 0.73169 \\
\hline $\mathrm{O}_{2}$ (non-reacting) & 0.20329 & 0.20329 \\
\hline & 1.0000 & 1.0000 \\
\hline
\end{tabular}

\begin{tabular}{|c|c|}
\hline \multicolumn{2}{|c|}{$\begin{array}{c}\text { Peak Pressure } \\
\text { (psi) }\end{array}$} \\
\hline BOM Measured & FIDAP \\
\hline 61.0 & 63.0 \\
\hline
\end{tabular}


WHC-SD-WM-ER-515, Rev. 0

Figure A-1. Bureau of Mines Test Chamber.

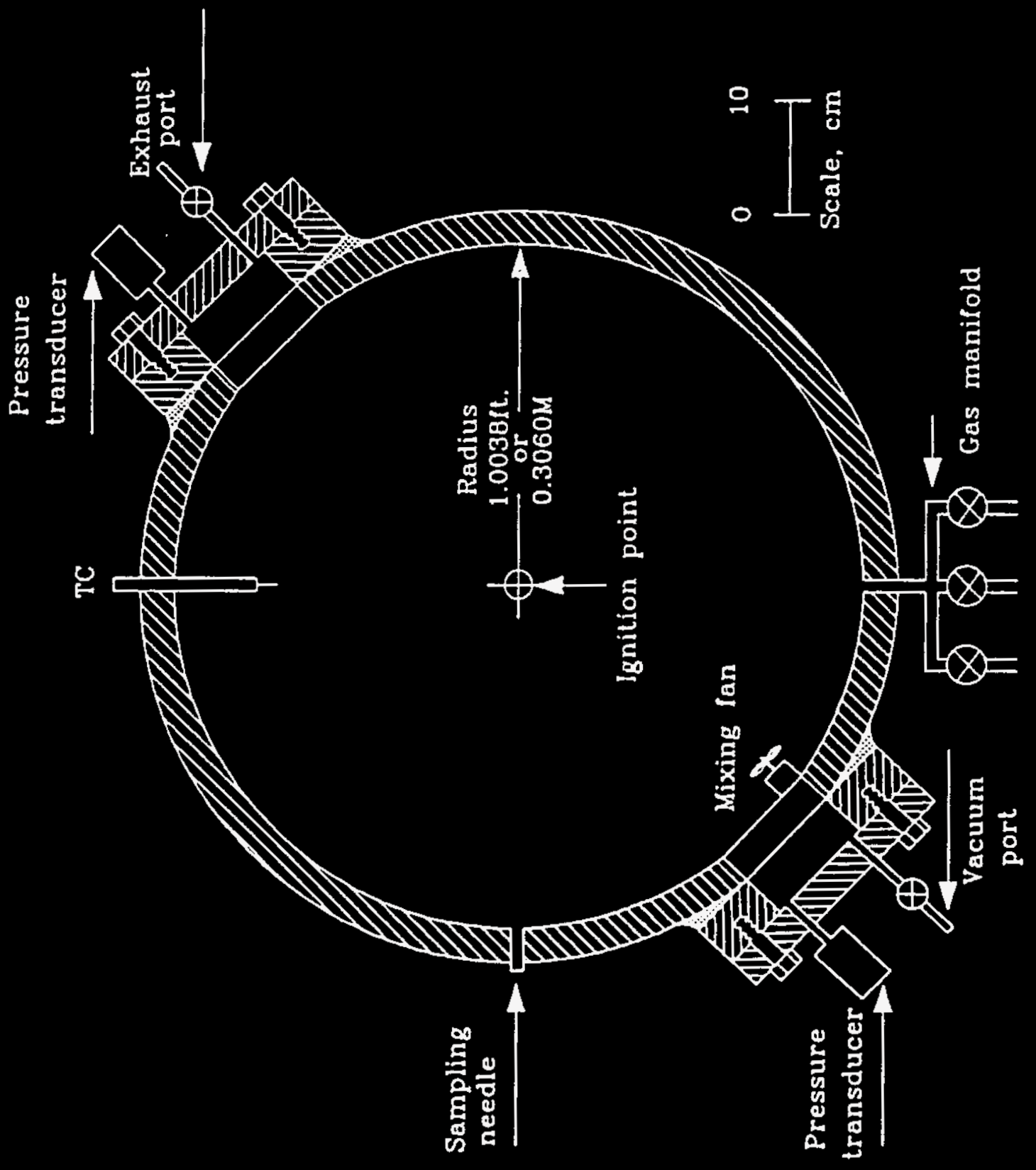

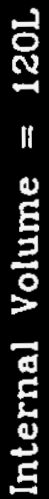


Figure A-2. Axi-Symmetric Finite Element Mesh Representation for Bureau of Mines Test Chamber.

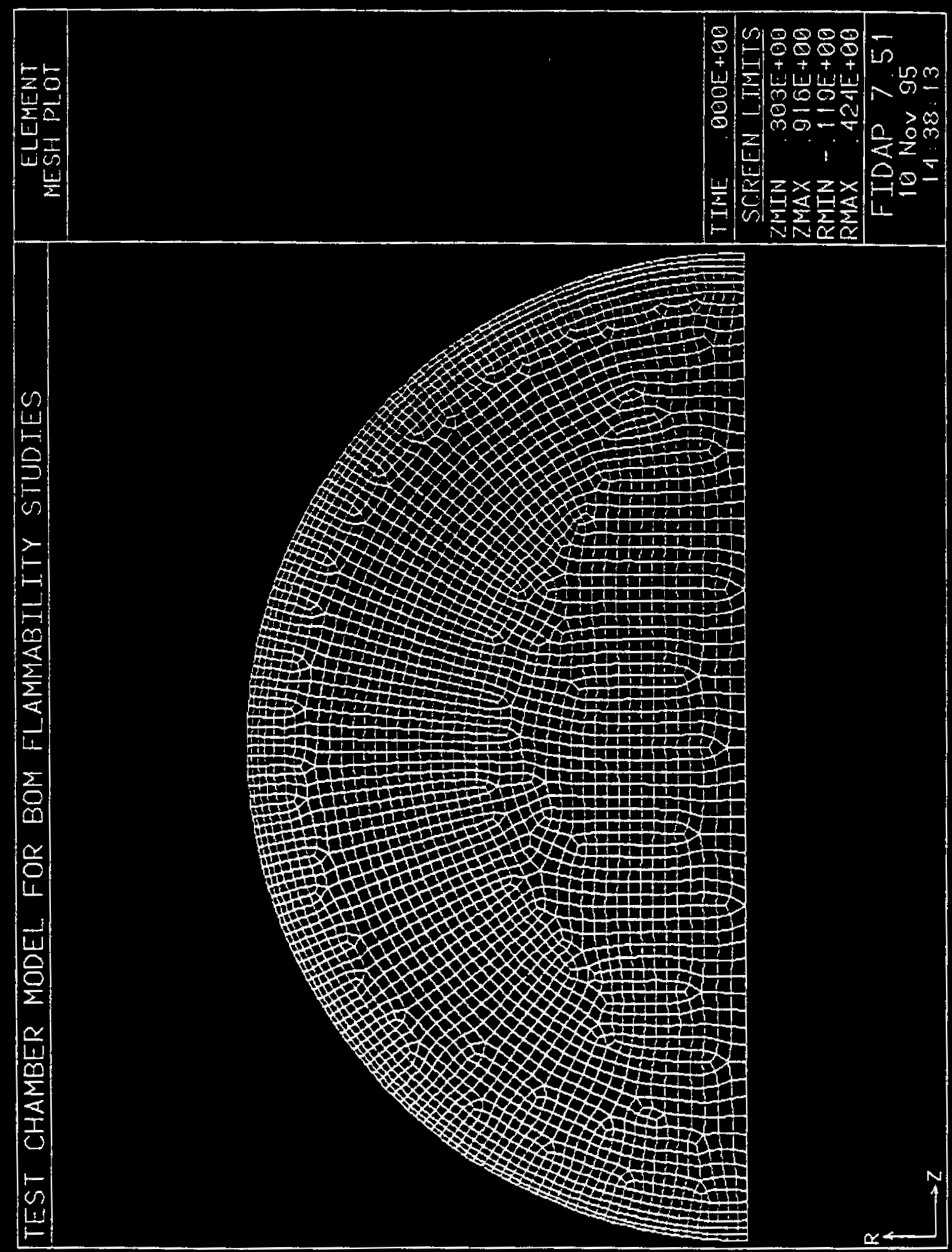


Figure A-3. Comparison of Pressure vs Time as Predicted by FIDAP and Measured by BOM for a Flammable-Gas Burn of 10 Percent $\mathrm{H}_{2}$ and $\mathrm{K}_{2} \mathrm{O}$ in Air.

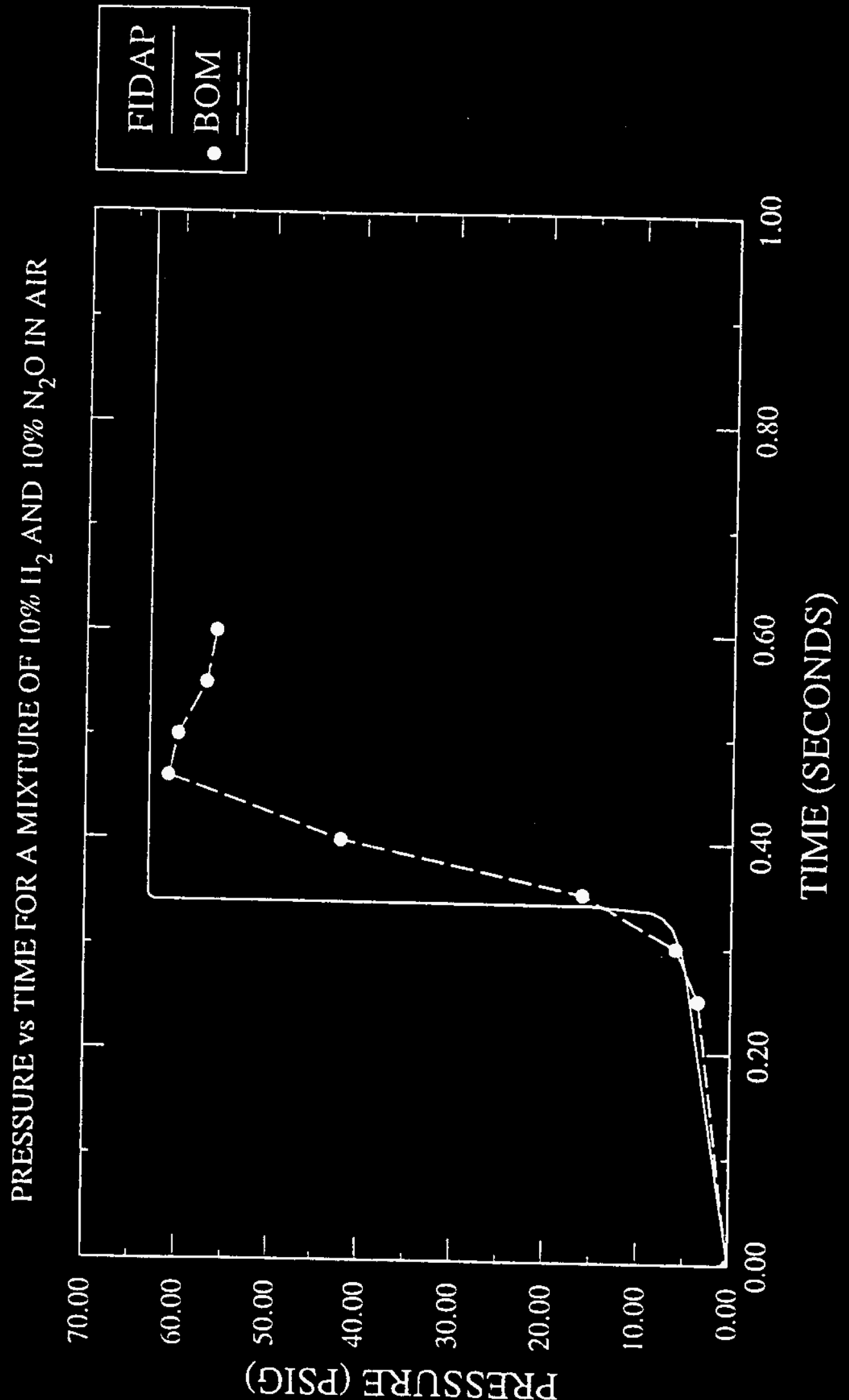


WHC-SD-WM-ER-515, Rev. 0

APPENDIX B. LISTING OF SUBROUTINE USRSPH - SPECIFIC HEAT OF MIXTURE. 


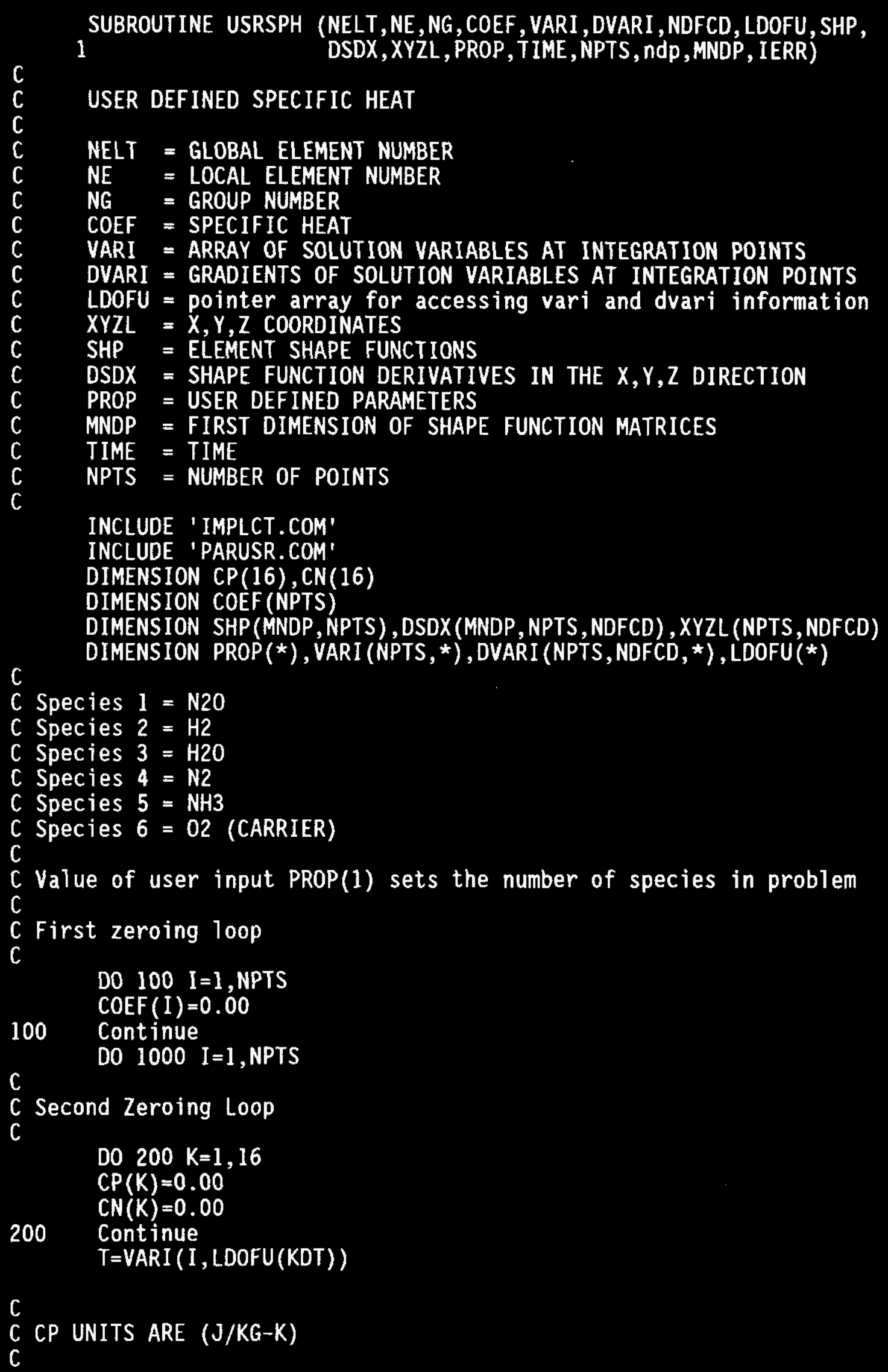


C

C CP FOR SPECIES $1=N 20$

$C P(1)=(511.684+1.57912 * T-.00134608 *(T * * 2)+6.80409 E-7$

$\$ *(T * * 3)-2.17584 E-10 *(T * * 4)+4.50439 E-14 *(T * * 5)$

$\$-6.00781 \mathrm{E}-18 *(T * * 6)+4.97391 \mathrm{E}-22$

$\$ *(T * * 7)-2.32155 E-26 *(T * * 8)+4.66215 E-31 *(T * * 9)) * 1.0$

C CP FOR SPECIES $2=\mathrm{H} 2$ $C P(2)=(14054.9-0.363663 * T+0.00226206 *(T * * 2)-1.06044 E-6$

$\$ *(T * * 3)+2.45459 E-10^{*}(T * * 4)-3.10242 E-14 *\left(T^{*} * 5\right)+2.03065 E-18$

$\$ *(T * * 6)-5.36708 \mathrm{E}-23 *(T * * 7)) * 1.0$

C CP FOR SPECIES $3=\mathrm{H} 20$ $C P(3)=(1883.03-0.503311 * T+0.00186039 *(T * * 2)-1.37006 E-6$

$\$ *(T * * 3)+5.29455 \mathrm{E}-10 *(T * * 4)-1.23423 \mathrm{E}-13 *(T * * 5)+1.79076 \mathrm{E}-17$

$\$ \star(T * \star 6)-1.58055 \mathrm{E}-21 *(T * * 7)+7.76009 \mathrm{E}-26 *(T * \star 8)$

$\$-1.62362 \mathrm{E}-30 *(T * * 9)) * 1.0$

$C$ CP SPECIES $4=N 2$ $C P(4)=(1040.98-0.124349 * T+0.000505846 *(T * * 2)$

$\$-3.69667 \mathrm{E}-7 *(T * * 3)+1.30595 \mathrm{E}-10 *(T * * 4)-2.56984 \mathrm{E}-14 *(T * \star 5)$

$\$+2.87017 \mathrm{E}-18 *(T * * 6)-1.69977 \mathrm{E}-22 *(T * * 7)+4.14204 \mathrm{E}-27$

$\$ *(T * * 8)) * 1.0$

C CP SPECIES $5=$ NH3

$C P(5)=(1492.19+2.42495 * T-0.000680172 *(T * * 2)+8.9451 E-8$

$\$ *(T * * 3)-5.49535 \mathrm{E}-12 *(T * * 4)+1.25088 \mathrm{E}-16 *(T * \star 5)) \star 1.0$

C CP FOR SPECIES $6=02$ (CARRIER)

$C P(6)=(842.302+0.356652 * T-0.000162807 *(T * * 2)$

$\$+5.10713 \mathrm{E}-8 *(T * * 3)-1.02138 \mathrm{E}-11 *(T * * 4)+1.24148 \mathrm{E}-15 *(T * * 5)$

C

$\left.\$-8.12474 \mathrm{E}-20 *(T * \star 6)+2.16896 \mathrm{E}-24^{*}(T * * 7)\right) * 1.0$

C

C

IF (PROP(1).LT.6) THEN

$T C=0.0$

DO $1100 \mathrm{~J}=1$, PROP(1)

$\mathrm{CN}(\mathrm{J})=\operatorname{VARI}(\mathrm{I}, \mathrm{LDOFU}(\mathrm{KDS}+\mathrm{J}))$

1100

$\mathrm{TC}=\mathrm{TC}+\mathrm{CN}(\mathrm{J})$

C

CONTINUE

C CALCULATE CARRIER MASS FRACTION

C

$C N(6)=1.0-T C$

C CALCULATE BLENDED CP OF GAS MIXTURE NOT INCLUDING CARRIER

C

CPMIX $=0.0$

DO $1200 \mathrm{~J}=1, \operatorname{PROP}(1)$

$C P M I X=C P M I X+C P(J) * C N(J)$

1200 CONTINUE

C

C ADD MASS FRACTION WEIGHTED CP OF CARRIER TO CP OF MIXTURE

$\mathrm{C}$

CPMIX $=C P M I X+C P(6) * C N(6)$

ELSE 
WHC-SD-WM-ER-515, Rev. 0

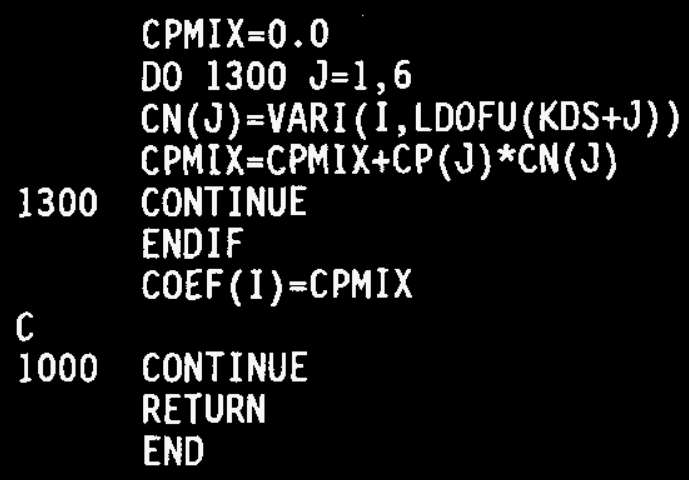

END 
WHC-SD-WM-ER-515, Rev. 0

APPENDIX C. HAS/TRAC COMBUSTION PARANETERS. 


\section{Los Alamos}

NATIONALLABOAATORY

Tehnology \& Setery Ascessment Division

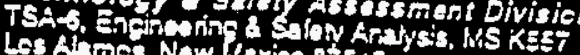

(Gos) esines. Now Raxies 87545

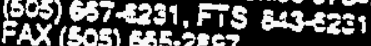

Aato: April 28, 1994

Fotorts: TSA-6-94-148

Dr. Fred Heard

PO Box 1970

Westinghouse Haniord Company

Richland, WA 99352

Dear Fred:

On 18 April 1994, you requested the HMSTRAC combustion parameters we used in Echs. (B-6) through (B-11) on p. B-4 of Appendix B in Revision 8 of Los Alamos repor
LA-UR-92-3196, "A Saiery Assessment Episodic Gas Release in Tank 241-SY-101: Hapsed Pump Mixing Operations to Mitigate paramerers are lisied in the table below

\begin{tabular}{|c|c|c|c|c|}
\hline $\begin{array}{l}\text { Equation } \\
\text { B-6 } \\
\text { B-7 } \\
\text { B-8 } \\
\text { B-9 } \\
\text { B-10 } \\
\text { B-11 }\end{array}$ & $\begin{array}{c}C_{i}\left(\mathrm{~cm}^{3} / \text { moles }\right) \\
6.0 e 12 \\
5.0 e 12 \\
1.2 e 14 \\
1.0 e 14 \\
6.0 e 13 \\
5.0 e 13\end{array}$ & $\begin{array}{c}f_{\mathrm{i}} \text { (dimensionless) } \\
1.0 \\
1.0 \\
1.0 \\
1.0 \\
1.0 \\
1.0\end{array}$ & $\begin{array}{c}\text { Oi (dimensioniess) } \\
1.0 \\
1.0 \\
1.0 \\
1.0 \\
1.0 \\
1.0\end{array}$ & $\begin{array}{c}E_{\mathrm{i}} \\
(\mathrm{J} / \mathrm{mole}) \\
6.2 \mathrm{et} \\
7.8 \mathrm{et} \\
1.7 \mathrm{et} \\
2.1 \mathrm{es} \\
2.7 \mathrm{es} \\
3.4 \mathrm{es}\end{array}$ \\
\hline
\end{tabular}

We continue to evaluate these parameters in terms of deualed chemical kinetics mechanisms and relevant data. Please keep us infommed of your experiences in combustion simulation.

Sincerely yours.

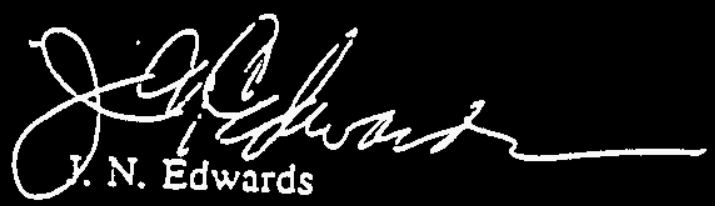

JNE/slv

Cys: J. Lentsch.WHC

J. Johnson. WHC

H. Sullivan, TSA-6. MS K557

A. Neuls. TSA-6, MS K557

J. Spore. TSA-6, MS K555

J. Travis. TSA-6. MS K555

CRM1-4. MS AISO)

TSA-6 Bile 
WHC-SD-WM-ER-515, Rev. 0

APPENDIX D. MASS FRACTIONS AS INPUT TO FIDAP FOR FLAMMABLE-GAS PLUME BURN ANALYSIS. 
WHC-SD-WM-ER-515, Rev. 0

Table D-1. Mass Fractions as Input to FIDAP for Flammable-Gas Plume Burn Analysis.

\begin{tabular}{|c|c|c|c|c|c|c|}
\hline \multirow[b]{3}{*}{$\#$} & \multirow[b]{3}{*}{ Species } & \multirow[b]{3}{*}{ MW } & \multicolumn{4}{|c|}{ Initial Mass Fractions } \\
\hline & & & \multicolumn{3}{|c|}{ Gas Pocket } & \multirow{2}{*}{$\begin{array}{c}\begin{array}{c}\text { Dome } \\
\text { Airspace }\end{array} \\
\begin{array}{c}\text { All } \\
\text { Reactions }\end{array}\end{array}$} \\
\hline & & & $\begin{array}{c}1 \text { Reaction } \\
50 / 50\end{array}$ & $\begin{array}{l}2 \text { Reactions } \\
\text { WHC Cons. }\end{array}$ & $\begin{array}{l}4 \text { React ions } \\
\text { WHC Cons. }\end{array}$ & \\
\hline 1 & $\mathrm{~N}_{2} \mathrm{O}$ & 44.013 & 0.9260 & 0.8641 & .8641 & 0.0 \\
\hline 2 & $\mathrm{H}_{2}$ & 2.016 & 0.0424 & 0.0247 & .0247 & 0.0 \\
\hline 3 & $\mathrm{H}_{2} \mathrm{O}$ & 18.015 & 0.0316 & 0.0276 & .0276 & 0.0 \\
\hline 4 & $\mathrm{~N}_{2}$ & 28.013 & 0.0 & 0.0 & 0.0 & 0.7552 \\
\hline 5 & $\mathrm{NH}_{3}$ & 17.030 & 0.0 & 0.0836 & .0836 & 0.0 \\
\hline \multirow[t]{2}{*}{6} & $\mathrm{O}_{2}$ & 31.999 & 0.0 & 0.0 & 0.0 & 0.2448 \\
\hline & & TOTAL & 1.0000 & 1.0000 & 1.0000 & 1.0000 \\
\hline
\end{tabular}


WHC-SD-WM-ER-515, Rev. 0

APPENDIX E. INPUT AND RESULT FILES FOR FLAMMABLE-GAS PLUME BURN ANALYSES. 
WHC-SD-WM-ER-515, Rev. 0

Table E-1. Summary of Input and Result Files for Flammable-Gas Plume Burn and Ventilation-System Response Analyses.

Flammable Gas Plume Burn (Path $=/ \mathrm{fjh} / \mathrm{small}$ burn)

\begin{tabular}{|c|c|c|c|}
\hline \multicolumn{3}{|c|}{ Filenene } & \multirow[b]{2}{*}{ Description } \\
\hline $\begin{array}{l}\text { Flammable Gas } \\
\text { Volupe } \\
\left(\mathrm{ft}^{\mathrm{s}}\right)\end{array}$ & $\begin{array}{l}\text { Input } \\
\text { (.input) }\end{array}$ & $\begin{array}{l}\text { Results } \\
\text { (.FDPOST) }\end{array}$ & \\
\hline \multirow[t]{4}{*}{75} & $75 s 1$. & $75 s 1$. & Steady-state \\
\hline & $\begin{array}{l}75+11 \\
75+12 \\
75+13\end{array}$ & $\begin{array}{l}75+11 \\
75+12 \\
75+13\end{array}$ & $\begin{array}{l}\text { Transient, } d t=.05 \mathrm{~s}, 1 \text { reaction } \\
\text { Transient, dt }=.01 \mathrm{~s}, 1 \text { reaction } \\
\text { Transient, dt }=.0025 \mathrm{~s}, 1 \text { reaction }\end{array}$ \\
\hline & $\begin{array}{l}75+21 \\
75+22 \\
75+23\end{array}$ & $\begin{array}{l}75+21 \\
75+22 \\
75+23\end{array}$ & $\begin{array}{l}\text { Transient, } d t=.05 \mathrm{~s}, 2 \text { react ions } \\
\text { Transient, } d t=.01 \mathrm{~s}, 2 \text { reactions } \\
\text { Transient, } d t=.0025 \mathrm{~s}, 2 \text { reactions }\end{array}$ \\
\hline & $\begin{array}{l}75+4 \\
75+41 \\
75+42\end{array}$ & $\begin{array}{l}75+4 \\
75+41 \\
75+42\end{array}$ & $\begin{array}{l}\text { Transient, } d t=.05 \mathrm{~s}, 4 \text { reactions } \\
\text { Transient, } d t=.01 \mathrm{~s}, 4 \text { reactions } \\
\text { Transient, dt }=.0025 \mathrm{~s}, 4 \text { reactions }\end{array}$ \\
\hline \multirow[t]{2}{*}{150} & 150 s1. & 150 s1. & Steady-state \\
\hline & $\begin{array}{l}150+4 \\
150+41 \\
150+42\end{array}$ & $\begin{array}{l}150+4 \\
150+41 \\
150+42\end{array}$ & $\begin{array}{l}\text { Transient, } d t=.05 \mathrm{~s}, 4 \text { reactions } \\
\text { Transient, } d t=.01 \mathrm{~s}, 4 \text { react ions } \\
\text { Transient, } d t=.0025 \mathrm{~s}, 4 \text { reactions }\end{array}$ \\
\hline \multirow[t]{3}{*}{300} & $300 \mathrm{~s} 1$. & $300 s 1$. & Steady-state \\
\hline & $\begin{array}{l}300+2 \\
300 t 21 \\
300+22\end{array}$ & $\begin{array}{l}300+2 \\
300+21 \\
300+22\end{array}$ & $\begin{array}{l}\text { Transient, } d t=.05 \mathrm{~s}, 2 \text { react ions } \\
\text { Transient, } d t=.01 \mathrm{~s}, 2 \text { react ions } \\
\text { Transient, } d t=.0025 \mathrm{~s}, 2 \text { reactions }\end{array}$ \\
\hline & $\begin{array}{l}300+4 \\
300+41 \\
300+42\end{array}$ & $\begin{array}{l}300+4 \\
300+41 \\
300+42\end{array}$ & $\begin{array}{l}\text { Transient, } d t=.05 \mathrm{~s}, 4 \text { reactions } \\
\text { Transient, } d t=.01 \mathrm{~s}, 4 \text { reactions } \\
\text { Transient, } d t=.0025 \mathrm{~s}, 4 \text { reactions }\end{array}$ \\
\hline
\end{tabular}

Ventilation System (Path $=/$ pulse/inlet)

\begin{tabular}{|c|c|c|c|}
\hline $\begin{array}{c}\text { Flamable fas Volune } \\
\left(\mathrm{ft}^{3}\right)\end{array}$ & Subdirectory & $\begin{array}{l}\text { Input/Results } \\
\text { Filenane }\end{array}$ & Number of Reactions \\
\hline 75 & $\begin{array}{l}1 \text { react } .75 \\
2 \text { react. } 75 \\
4 \text { react. } 75\end{array}$ & $\begin{array}{l}101 \text { cvent } \\
101 \text { cvent } \\
101 \text { crent }\end{array}$ & $\begin{array}{l}1 \\
2 \\
4\end{array}$ \\
\hline 150 & 4 react. 150 & 101 crent & 4 \\
\hline 300 & $\begin{array}{l}2 \text { react } .300 \\
4 \text { react } .300\end{array}$ & $\begin{array}{l}\text { 101cvent } \\
\text { lo1cvent }\end{array}$ & $\begin{array}{l}2 \\
4 \\
\end{array}$ \\
\hline
\end{tabular}

This input and corresponding result files for the flammable-gas plume burn and ventilation-system response analyses have been backed up onto a 8-mm tape for archival purposes and will be stored in the engineering task specification file associated with these analyses (WFM-94-029). 


\section{DISTRIBUTION SHEET}

\begin{tabular}{|c|c|c|c|c|c|}
\hline \multirow{2}{*}{$\begin{array}{l}\text { To } \\
\text { Distribution }\end{array}$} & \multirow{2}{*}{\multicolumn{3}{|c|}{$\begin{array}{l}\text { From } \\
\text { Plant Systems Safety Basis }\end{array}$}} & \multicolumn{2}{|c|}{ Page 1 of 1} \\
\hline & & & & \multicolumn{2}{|c|}{ Date $01 / 03 / 96$} \\
\hline \multirow{2}{*}{\multicolumn{4}{|c|}{$\begin{array}{l}\text { Project Title/Work Order } \\
\text { N2150 }\end{array}$}} & \multicolumn{2}{|c|}{ EDT No. 613538} \\
\hline & & & & \multicolumn{2}{|c|}{ ECN No. NA } \\
\hline Name & MSIN & $\begin{array}{l}\text { Text } \\
\text { With All } \\
\text { Attach. }\end{array}$ & Text Only & $\begin{array}{l}\text { Attach./ } \\
\text { Appendix } \\
\text { Only }\end{array}$ & $\begin{array}{l}\text { EDT/ECN } \\
\text { Only }\end{array}$ \\
\hline 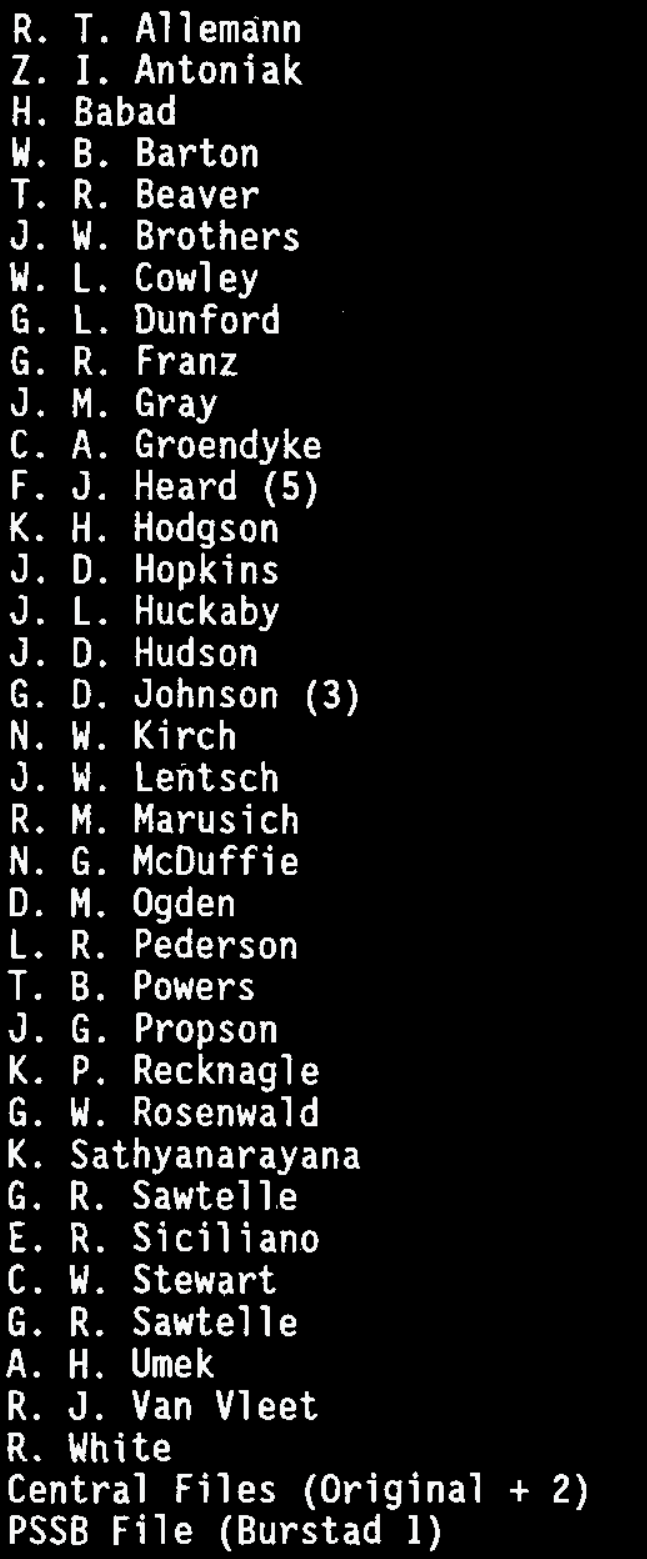 & $\begin{array}{l}\text { K7-15 } \\
\text { K7-15 } \\
\text { S7-15 } \\
\text { R2-11 } \\
\text { HO-34 } \\
\text { K5-22 } \\
\text { A3-37 } \\
\text { R2-36 } \\
\text { S7-81 } \\
\text { S7--54 } \\
\text { S7-54 } \\
\text { HO--34 } \\
\text { R2-11 } \\
\text { R2-11 } \\
\text { K6-80 } \\
\text { K7-15 } \\
\text { S7-15 } \\
\text { R2-11 } \\
\text { S7-15 } \\
\text { A3-34 } \\
\text { S7-15 } \\
\text { HO-34 } \\
\text { K2-44 } \\
\text { A3-34 } \\
\text { R2-36 } \\
\text { K7-15 } \\
\text { S7-54 } \\
\text { H0-34 } \\
\text { A3-37 } \\
\text { HO-31 } \\
\text { K7-15 } \\
\text { A3-37 } \\
\text { S7-81 } \\
\text { A3-34 } \\
\text { H5-09 } \\
\text { A3-88 } \\
\text { HO-34 }\end{array}$ & 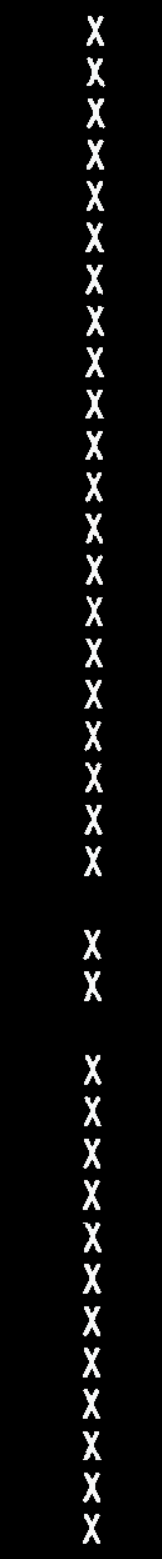 & & & $x$ \\
\hline $\begin{array}{l}\text { W. Kubic } \\
\text { Los Alamos National Laboratory } \\
\text { P.0. Box } 1663 \text { K551 } \\
\text { Los Alamos, New Mexico } 87545\end{array}$ & $\begin{array}{l}\text { Los Ala } \\
\text { P.0. Bo } \\
\text { Los Ala } \\
\text { Jack Ed } \\
\text { Jay Spo }\end{array}$ & $\begin{array}{l}\text { hos Natio } \\
1663 \mathrm{~K} \\
\text { nos, New } \\
\text { ards } \\
\text { e }\end{array}$ & axico 875 & & \\
\hline
\end{tabular}

